UNIVERSIDADE DE SÃO PAULO

INSTITUTO DE QUÍMICA DE SÃO CARLOS-IQSC

Departamento de Físico-Química

Grupo de Físico-Química Orgânica

\title{
Síntese e caracterização de derivados 3,6-O,O'- dimiristoil quitosana para encapsulação e liberação de fármacos antitumorais
}

Tese apresentada ao Instituto de Química de São Carlos como parte dos requisitos para obtenção do título de Doutor em Ciências (Físico-Química).

Daniella de Souza e Silva

Orientador: Prof. Dr. Sérgio Paulo Campana-Filho

São Carlos

Junho / 2017 



\section{Daniella de Souza e Silva}

\section{Síntese e caracterização de derivados 3,6-O,O'- dimiristoil quitosana para encapsulação e liberação de fármacos antitumorais}

Tese apresentada ao Instituto de Química de São Carlos como parte dos requisitos para obtenção do título de Doutor em Ciências (Físico-Química).

Orientador: Prof. Dr. Sérgio Paulo Campana Filho 
Autorizo a reprodução e divulgaçào total ou parcial deste trabalho, por qualquer meio convencional ou eletrônico para fins de estudo e pesquisa, desde que citada a fonte.

Assinatura: Danuella de \& Silia Data: $12 \log 117$

Silva, Daniella Souza e

Sintese e caracterização de derivados 3,6-0,0'- dimiristoil quitosana para encapsulação e liberaçăo de fármacos antitumorais / Daniella Souza e Silva. São Carlos, 2017.

$143 \mathrm{f}$.

Tese (Doutorado em Fisico-Química) - Instituto de Quimica de São Carlos I Universidade de Sảo Paulo, 2017.

Edição revisada

Orientador: Prof. Dr. Sérgio Paulo Campana Filho

1. Biopolimeros. 2. Quitosana. 3. Micelas. 4. Paclitaxel. 5. Camptotecina. 1. Titulo. 
Dedico este trabalho à Deus, e em especial aos meus pais Daniel e Rute, meu irmão Luiz e meu namorado Enio, pelo apoio, por acreditarem e me ensinarem o valor dos estudos e da dedicação. Dedico também às minhas amigas e amigos que sempre estiveram ao meu lado nessa jornada em busca do conhecimento. 

fiqueles que estiveram junto a mim durante esta jornada. 



\section{AGRADECIMENTOS}

À Deus pelo dom da vida, pela força e proteção. Por guiar meus passos e me mostrar que tudo acontece no tempo certo!

Ao Prof. Sérgio Paulo Campana Filho pela orientação, ensinamentos, dedicação, confiança e sobre tudo pela amizade.

Ao Prof. Bruno Sarmento pela co-orientação, discussões acadêmicas, amizade e o acolhimento junto ao seu grupo de pesquisa no I3S- Portugal.

Aos técnicos do IQSC e do I3s, André, Aldimar, Carlos Bento, Luis, Silvana, Thiago, Márcio, Nilza, Zélia, Paula, Ricardo e Rui.

À minha família pelo apoio incondicional, amor eterno e por sempre acreditarem em mim. Pai e mãe todo esse esforço foi por e graças a vocês. Ao meu irmão obrigado pela paciência e por ser quem é.

À Virgínia e a Joice pela cumplicidade, companheirismo e dedicação. Vocês foram fundamentais nesse processo!

Ao meu namorado Enio pelo companheirismo, apoio, dedicação e incentivo.

Aos meus amigos Anderson, Adriana, Andrea, Danilo, William, Juliana, Jorge, Tonimar, Bianca, Amanara, Fabiana, Fran, Jussara, Ana Costa, Rute, Cassilda, Elizabete e Flávia pelo acolhimento, discussões científicas e bons momentos. Em especial a Andreia e a Fabíola pelo companheirismo, confiança e amizade.

À USP e ao I3s pela excelente infraestrutura e a CAPES pelo apoio financeiro.

Enfim, deixo aqui meus sinceros agradecimentos a todos aqueles que, direta ou indiretamente contribuíram para realização deste trabalho, assim como para meu crescimento profissional e pessoal. 

"Eu tentei 99 vezes e falhei, mas na centésima tentativa eu consegui, nunca desista de seus objetivos mesmo que pareçam impossíveis. " Albert Einstein

"A persistência é o menor caminho para o êxito." Charlie Chaplin 



\section{RESUMO}

\section{SILVA, D. S. Síntese e caracterização de derivados 3,6-O,O'- dimiristoil quitosana para}

encapsulação e liberação de fármacos antitumorais. 2017. 143 f. Tese (Doutorado) - Instituto de Química de São Carlos. Universidade de São Paulo, São Carlos, 2017.

O presente trabalho teve como objetivo produzir 3,6-O, $O^{\prime}$-dimisritoilquitosana (QDM) com baixo grau médio de substituição $(\overline{\boldsymbol{G S}} \leq 10 \%)$ a partir da reação de quitosana com cloreto de miristoíla, de maneira a conferir caráter anfifílico às cadeias poliméricas. Neste estudo foram empregadas diferentes quitosanas de partida, a saber, quitosana de origem comercial (QC), que apresenta baixo grau médio de acetilação $(\overline{\boldsymbol{G A}}=5 \%)$ e baixa massa molar média viscosimétrica $(\overline{\boldsymbol{M} \boldsymbol{v}}=87,000 \mathrm{~g} / \mathrm{mol}$ ), e quitosana DAIUS (QD), produzida a partir da desacetilação de betaquitina assistida por irradiação de ultrassom de alta intensidade, que apresenta $\overline{\boldsymbol{G A}}=15 \%$ e $\overline{\boldsymbol{M v}}$ $=300,000 \mathrm{~g} / \mathrm{mol}$. Para obtenção dos derivados QDM, diferentes razões molares quitosana/cloreto de miristoíla $(\mathrm{Q} / \mathrm{CM})$ foram empregadas $(1: 0,075 ; 1: 0,1 ; 1: 0,2$ e 1:0,5), e as reações foram executadas por $1 \mathrm{~h}$ a $25{ }^{\circ} \mathrm{C}$. As características estruturais e morfológicas das amostras geradas neste trabalho foram determinadas pelo emprego de espectroscopias de ressonância magnética nuclear e no infravermelho e difração de raios X. A solubilidade das amostras foi investigada por espectroscopia UV/visível e a estabilidade térmica foi estudada através de análise termogravimétrica. A partir da análise de espectroscopia no infravermelho, foi possível evidenciar a ocorrência da reação de acilação seletiva dos grupos $\mathrm{OH}$ das quitosanas, através da presença da banda observada em $1740 \mathrm{~cm}^{-1}$, referente à deformação axial de carbonila de éster, resultante da reação de $O$-acilação. A banda em $1577 \mathrm{~cm}^{-1}$ referente a $N$-acilação não foi evidenciada. Na segunda etapa deste estudo as amostras QCM1 $(\overline{\boldsymbol{D S}}=6,6 \%)$ e QCM4 $(\overline{\boldsymbol{D S}}=11$ $\%$ ), que apresentaram concentrações críticas de agregação (CAC) $8,9 \times 10^{-3} \mathrm{mg} / \mathrm{mL}$ e $13,2 \times 10^{-}$ ${ }^{3} \mathrm{mg} / \mathrm{mL}$, respectivamente, foram empregadas nos estudos de encapsulação e liberação de paclitaxel e camptotecina, fármacos hidrofóbicos anti-câncer insolúveis em água. A análise de microscopia eletrônica de transmissão (MET) mostrou que as micelas de QCM apresentaram formas aproximadamente esféricas, enquanto que o espalhamento dinâmico de luz (DLS) permitiu a determinação do diâmetro médio das micelas carregadas e vazias, que variou no intervalo $280 \mathrm{~nm}-481 \mathrm{~nm}$, enquanto o potencial zeta foi $\geq+30 \mathrm{mV}$. As micelas de QCM foram capazes de encapsular o paclitaxel e a camptotecina com elevada eficiência de encapsulação (EE 
> $60 \%$ ), como confirmado por análises de HPLC e UV-vis. As micelas não apresentaram citotoxicidade em relação às células Caco-2 e HT29-MTX e que a encapsulação diminuiu a toxicidade de paclitaxel e camptotecina. Os estudos de permeação de paclitaxel e a camptotecina encapsulados em micelas de DMQ através da monocultura de Caco-2 e do modelo de co-cultura Caco-2 / HT29-MTX confirmaram o potencial das micelas na melhoria da absorção intestinal dos fármacos. Os estudos de liberação com ambos fármacos mostraram perfis de liberação sustentada. Os resultados obtidos sugerem que as micelas de QCM podem ser carreadoras promissoras para encapsular paclitaxel e camptotecina.

Palavras-chave: Quitosana, derivados anfifílicos, micelas polimericas, paclitaxel, camptotecina, liberação de fármaco. 


\begin{abstract}
SILVA, D. S. Synthesis and characterization of 3,6-O, $\boldsymbol{O}^{\prime}$-dimyristoyl chitosan derivatives for encapsulation and release of antitumor drugs. 2017. $143 \mathrm{f}$. Tese (Doutorado) - Instituto de Química de São Carlos. Universidade de São Paulo, São Carlos, 2017.
\end{abstract}

The aim of this work was to produce 3,6-O, $O^{\prime}$-dimisyltiylchitosan (QDM) with low degree of substitution (GS $\leq 10 \%$ ) from the reaction of chitosan with myristoyl chloride, in order to confer amphiphilic characteristics to the polymeric chains. In this study, different chitosan starting materials were used, namely commercial chitosan (QC), which had a low average degree of acetylation $(\overline{\boldsymbol{G A}}=5 \%)$ and a low viscosity molar mass $(\overline{\boldsymbol{M v}}=87,000 \mathrm{~g} / \mathrm{mol})$, and USAD chitosan (QD), produced from the beta-chitin ultrasound assisted deacetylation process (USAD Process), which presents $\overline{\boldsymbol{G A}}=15 \%$ and $\overline{\boldsymbol{M} \boldsymbol{v}}=300,000 \mathrm{~g} / \mathrm{mol}$. Different molar ratios chitosan / myristoyl chloride (Q/CM) were used (1: 0.075, 1: 0.1, 1: 0.2 and 1: 0.5) to obtain the QDM derivatives, all of them under a constant temperature of $25^{\circ} \mathrm{C}$ with reaction time of 1 hour. The structural and morphological characteristics of the samples generated in this work were determined by infrared and nuclear magnetic resonance spectroscopy and X-ray diffraction. The solubility of the samples was investigated by UV/visible spectroscopy and the thermal stability was studied by thermogravimetric analysis. From the infrared spectroscopy analysis, it was possible to show the occurrence of the selective acylation reaction of the $\mathrm{OH}$ groups of chitosan through the presence of the band observed in $1740 \mathrm{~cm}^{-1}$, which refers to the axial deformation of ester carbonyl from reaction of $O$-acylation. The band at $1577 \mathrm{~cm}^{-1}$ of $N$-acylation was not evidenced. Moreover, the samples QCM1 and QCM4, which presented critical aggregation concentrations of $8.9 \times 10^{-3}$ $\mathrm{mg} / \mathrm{mL}$ and $13.2 \times 10^{-3} \mathrm{mg} / \mathrm{mL}$, respectively, were selected for encapsulation and release studies of water-insoluble anti-cancer hydrophobic drugs, paclitaxel and camptothecin. Transmission electron microscopy (TEM) analyses showed that QCM micelles presented roughly spherical shapes, and dynamic light scattering (DLS) allowed the determination of the mean diameter of charged and empty micelles, which varied between $280 \mathrm{~nm}$ and $481 \mathrm{~nm}$, and the zeta potential, which was $\geq+30 \mathrm{mV}$. QCM micelles were able to encapsulate paclitaxel and camptothecin with high encapsulation efficiency (EE> 60\%), as confirmed by HPLC and UV-vis analyses. Furthermore, the micelles did not exhibit cytotoxicity in relation to Caco-2 and HT29-MTX cells, and the encapsulation decreased the toxicity of paclitaxel and camptothecin. Permeability 
studies of paclitaxel and camptothecin encapsulated in DMQ micelles through Caco-2 monoculture and Caco-2 / HT29-MTX co-culture model confirmed the potential of micelles on the improvement of intestinal absorption of drugs. The release studies with both drugs showed sustained release profiles. Hence, the results obtained suggest that the QCM micelles may be promising carriers for encapsulating paclitaxel and camptothecin.

Keywords: Chitosan, amphiphilic derivatives, polymeric micelles, paclitaxel, camptothecin, drug delivery. 


\section{LISTA DE FIGURAS}

Figura 1: Estrutura química do paclitaxel.

Figura 2: Mecanismo de ação do paclitaxel.

Figura 3: Estrutura química da camptotecina.

Figura 4: Estruturas química da camptoecina dependendo do $\mathrm{pH}$, lactona na forma ativa em $\mathrm{pH}$ abaixo de 5 e o carboxilato na forma inativa em $\mathrm{pH}$ básico. 31

Figura 5: Mecanismo de ação da camptotecina. 32

Figura 6: Representação da estrutura primária idealizada de quitosana, onde n é o grau médio de polimerização. 35

Figura 7: Esquema reacional da síntese dos derivados 3,6-O,O’' dimiristoilquitosana. 43

Figura 8: Esquema da obtenção de micelas via evaporação do solvente. 44

Figura 9: Espectro de $\mathrm{RMN}{ }^{1} \mathrm{H}(400 \mathrm{MHz})$ adquirido a $80^{\circ} \mathrm{C}$ a partir da solução da amostra QC em $\mathrm{DCl} / \mathrm{D}_{2} \mathrm{O} 1 \%(\mathrm{v} / \mathrm{v})$.

Figura 10: Espectro de $\mathrm{RMN}^{1} \mathrm{H}$ (400 MHz) da amostra QCM2, solubilizada em DCl/ $\mathrm{D}_{2} \mathrm{O} 1 \%$ (v/v), $80^{\circ} \mathrm{C}$.

Figura 11: Espectro de RMN ${ }^{13} \mathrm{C}$ no estado sólido das amostras de quitosana (a) e QCM1 (b)..... 64 Figura 12: Espectros na região do infravermelho das amostras QC e QCM2. 66

Figura 13: Espectros na região do infravermelho das amostras do derivado 3,6-O,O'miristoilquitosana proveniente da quitosana QC.

Figura 14: Espectros na região do infravermelho das amostras do derivado 3,6-O,O'miristoilquitosana proveniente da quitosana QD. 68

Figura 15: Difratogramas das amostras de quitosana a) QC e b) QD. 69

Figura 16: Difratogramas das amostras a) QCM1; b) QCM2; c) QCM3 e d) QCM4. 71

Figura 17: Difratogramas das a mostras a) QD, QDM1 e QDM2; e b) QC, QCM3 e QCM4. ...... 72 Figura 18- Curvas TG/DTG das amostras a) QC e b) QD, sob atmosfera dinâmica de ar sintético (vazão de gás $20 \mathrm{~mL} / \mathrm{min}$ ), massa da amostra $8 \mathrm{mg}$, suporte de amostra de platina. 74 
Figura 19: Curvas TG/DTG dos derivados da quitosana QC a) QCM1; b) QCM2; c) QCM3 e d) QCM4, sob atmosfera dinâmica de ar sintético (vazão de gás $20 \mathrm{~mL} / \mathrm{min}$ ), massa da amostra 8mg, suporte de amostra de platina.

Figura 20: Curvas TG/DTG dos derivados da quitosana QD a) QDM1; b) QDM2; c) QDM3 e d) QDM4, sob atmosfera dinâmica de ar sintético (vazão de gás $20 \mathrm{~mL} / \mathrm{min}$ ), massa da amostra 8mg, suporte de amostra de platina.

Figura 21: Gráfico do pH versus transmitância (comprimento de onda de $600 \mathrm{~cm}^{-1}$ ) das soluções de quitosana e dos derivados 3,6-O,O'- miristoilquitosana.

Figura 22: Imagens de ângulo de contato em água faz amostras de (A) quitosana, (B) QCM1 e (C) QCM4.

Figura 23: Curva da condutividade especifica versus a função logarítma da concentração das amostras DCM1 e DCM4 no intervalo de $1 \mathrm{mg} / \mathrm{mL}$ a $1.10^{-6} \mathrm{mg} / \mathrm{mL}$ .83

Figura 25: Curva analítica da área dos picos dos cromatogramas em função da concentração de PTX.

Figura 26: Gráfico de distribuição de tamanho por intensidade de espalhamento de luz da QCM1 com 2\% de PTX, representativo para todas as demais amostras. 89

Figura 27: Imagens de MET da amostra QCM1 (a e b) e QMC4* (c e d) carregadas com 2\%, com escala correspondente a (a e c) 100nm e (b e d) 200nm, respectivamente. 92

Figura 28: Viabilidade celular de QCM1, QCM1- PTX e PTX livre, contra a linha celular Caco-2 nas concentrações de 0,001-100 $\mu \mathrm{g} / \mathrm{mL}$ após incubação durante $24 \mathrm{~h}$. Os valores foram relatados como média \pm DP $(n=3)$. (**) e $(* * *)$ denota uma diferença significativa $(\mathrm{p}<0,01$ e $\mathrm{p}<0,001) .95$

Figura 29: A viabilidade celular de QCM1, QCM1- PTX e PTX livre, contra a linha celular HT29MTX nas concentrações de 0,001-100 $\mu \mathrm{g} / \mathrm{mL}$ após incubação durante 24 horas. Os valores foram relatados como média \pm DP $(n=3)$. (**) e (***) denota uma diferença significativa. .95

Figura 30: Esquema representativo do crescimento de monocamadas dos modelos celulares usados nos estudos de permeabilidade. 97

Figura 31: Imagens de acompanhamento do crescimento e formação das monocamadas celulares: (a) células Caco-2 crescendo em frasco T75; (b) células HT29-MTX em frasco T75; (c) terceiro dia do crescimento da monocamada do modelo de monocultura (Caco-2); (d) vigésimo primeiro dia de crescimento da monocamada da monocultura; (e) quarto dia de 
crescimento do modelo de co-cultura (Caco-2/HT29-MTX); (f) vigésimo primeiro dia de crescimento da monocamada da co-cultura; (g) branco no segundo dia e (h) branco no vigésimo primeiro dia.

Figura 32: Gráfico dos valores de TEER em função do tempo, medido durante os 21 dias de formação da monocamada para o modelo de monocultura (células Caco-2).

Figura 33: Gráfico dos valores de TEER em função do tempo, medido durante os 21 dias de formação da monocamada para o modelo de co-cultura (células Caco-2 / HT29-MTX). 100

Figura 34: Perfil de permeabilidade cumulativa in vitro de micelas carregadas com PTX através dos modelos de monocultura Caco-2 e co-cultura Caco-2 / HT29-MTX (०). Todos os experimentos foram conduzidos do compartimento apical ao basolateral em HBSS a $37^{\circ} \mathrm{C}$. As barras de erro representam a média \pm DP $(\boldsymbol{n}=3)$.

Figura 35: O perfil de liberação de PTX após incubação em fluido gástrico simulado (FGSE) pH= 1,2 e fluido intestinal simulado (FISE) $\mathrm{pH}=6,8$, todos sem a presença de enzimas, mantidos sob condições de lavagem a $37^{\circ} \mathrm{C}$. Dados expressos como média SD, $\boldsymbol{n}=3$.

Figura 36: Gráfico do espectro de absorção na região do UV para o CPT solúvel em DMSO... 106 Figura 37: Gráfico do espectro de absorção na região do UV para o polímero QCM1 solúvel em ácido acético 0,1 M e espectro do fármaco CPT em menor escala.

Figura 38: Curva analítica da absorbância em função da concentração de CPT, obtida por espectrofotometria na região do UV, com comprimento de onda máxima absorção em $370 \mathrm{~nm} .108$ Figura 39: Curva de distribuição de tamanho por intensidade de espalhamento de luz da QCM1CPT2, representativo para todas as demais amostras.

Figura 40: Imagens de MET que mostram a forma e o tamanho de DMC*-CPT2, com escala correspondente a (a) $100 \mathrm{~nm}$ e (b) $200 \mathrm{~nm}$.

Figura 41: A viabilidade celular de QCM1, QCM1- CPT2 e CPT livre, contra a linha celular Caco2 nas concentrações de $0,001-100 \mu \mathrm{g} / \mathrm{mL}$ após incubação durante $24 \mathrm{~h}$. Os valores foram relatados como média \pm DP $(\mathrm{n}=3)$. $(* *)$ e $(* * *)$ denota uma diferença significativa.

Figura 42: A viabilidade celular de QCM1, QCM1- CPT e CPT livre, contra a linha celular HT29MTX nas concentrações de 0,001-100 $\mu \mathrm{g} / \mathrm{mL}$ após incubação durante $24 \mathrm{~h}$. Os valores foram relatados como média $\pm \mathrm{DP}(\mathrm{n}=3)$. (**) e $(* * *)$ denota uma diferença significativa. 115 
Figura 43: Gráfico dos valores de TEER em função do tempo, medido durante os 21 dias de formação da monocamada para o modelo de monocultura (células Caco-2).

Figura 44: Gráfico dos valores de TEER em função do tempo, medido durante os 21 dias de formação da monocamada para o modelo de co-cultura (células Caco-2/ HT29-MTX).

Figura 45: Perfil de permeabilidade cumulativa in vitro de micelas carregadas com CPT através do modelo de monocultura Caco-2 . Todos os experimentos foram conduzidos do compartimento apical ao basolateral em HBSS a $37^{\circ} \mathrm{C}$. As barras de erro representam a média \pm DP $(\boldsymbol{n}=3) \ldots 118$ Figura 46: Perfil de permeabilidade cumulativa in vitro de micelas carregadas com CPT através do modelo de co-cultura Caco-2 / HT29-MTX. Todos os experimentos foram conduzidos do compartimento apical ao basolateral em HBSS a $37^{\circ} \mathrm{C}$. As barras de erro representam a média \pm DP $(\boldsymbol{n}=3)$.

Figura 47: O perfil de liberação de camptotecina após incubação em fluido gástrico simulado (FGSE) (0-2h) e fluido intestinal simulado (FISE) (2-48h) sob condições de lavagem a $37^{\circ} \mathrm{C}$. Dados correspondentes ao perfil de libertação durante 48h. Dados expressos como Média \pm DP, $n=3$.... 120 Figura 48: Gráfico correspondente a ampliação da Figura 47 no intervalo de tempo de 0-4 h..... 121 


\section{LISTA DE TABELAS}

Tabela 1: Amostras de 3,6-O,O'-dimiristoilquitosana preparadas a partir de quitosana comercial (QCMx) e de quitosana DAIUS (QDMx) empregando diferentes razões molares quitosana/cloreto de miristoíla 44

Tabela 2: Valores de grau de substituição (GS) dos derivados 3,6-O,O'- dimiristoilquitosana (QCMx e QDMx).

Tabela 3: Principais bandas de absorção e números de onda $\left(\mathrm{cm}^{-1}\right)$ das amostras de quitosana QC e QD

Tabela 4: Principais bandas de absorção e números de onda $\left(\mathrm{cm}^{-1}\right)$ dos derivados 3,6-O,O'dimiristoilquitosana

Tabela 5: Valores de índice de cristalinidade das amostras de quitosana Qc e QD e seus derivados com os respectivos valores de razão molar

Tabela 6: Valores de temperatura de desidratação relacionada ao primeiro evento das amostras de quitosana comercial (QC) e quitosana Daius (QD)..... 74

Tabela 7: Valores de temperatura de decomposição relacionada ao segundo evento das amostras de quitosana comercial (QC) e quitosana Daius (QD). 75

Tabela 8- Valores de temperatura de desidratação térmica curva DTG e perda de massa curva TG das amostras aciladas

Tabela 9: Valores de temperatura de decomposição relacionada ao segundo evento térmico das amostras dos derivados derivados 3,6-O,O'- miristoilquitosana(QCMx e QCDx) 76

Tabela 10: Dados das caracterizações de diâmetro médio, índice de polidispersividade, potencial zeta e eficiência de encapsulação

Tabela 11: Precisão intra-dia calculado a partir de três concentrações diferentes em um mesmo dia

Tabela 12: Precisão inter-dias calculado a partir de três concentrações diferentes 109

Tabela 13: Valores de exatidão calculados para as diferentes concentrações de CPT 110

Tabela 14: Valores de diâmetro, índice de polidispersidade (PDI), potencial zeta e eficiência de encapsulação das micelas QCM1 



\section{LISTA DE SIGLAS E ABREVEATURAS}

$\overline{G A}$ - grau médio de acetilação;

$\overline{G S}$ - grau médio de substituição;

$\overline{M v}$ - massa molar viscosimétrica média;

CAC- concentração micelar crítica;

CM- cloreto de miristoíla;

CPT- camptotecina;

DAIUS- desacetilação da quitina assistida por irradiação de ultrassom de alta intensidade;

DAIUS- desacetilação da quitina assitida por irradiação de ultrassom de alta intensidade;

DLS- espalhamento dinâmico de luz;

DMSO- dimetilsulfoxido;

DTG- análise termogravimétrica derivada;

FGSE- fluido gástrico simulado sem enzima;

FISE- fluido intestinal simulado sem enzima;

GlcN- 2-amido-2-desoxi-D-glicopiranose;

GlcNAc- 2-acetamido-2-desoxi-D-glicopiranose;

HPLC- cromatografia liquida de alta eficiência;

MET- microscopia eletrônica de transmissão;

PTX-paclitaxel;

Q- quitosana;

QC- quitosana comercial;

QCM- 3,6-O,O'- miristoilquitosana comercial;

QD- quitosana DAIUS;

QDM- 3,6-O,O'- miristoilquitosana DAIUS;

$\mathrm{RMN}^{1} \mathrm{H}$ - espectroscopia de ressonância nuclear magnética de hidrogênio;

TEER- resistência elétrica transepitelial;1

TGA- análise termogravimétrica;

UV-Vis- espectroscopia de ultravioleta no visível; 



\section{SUMARIO}

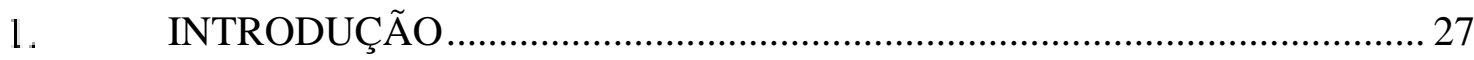

1.1. Anticancerígenos derivados de plantas.......................................................... 28

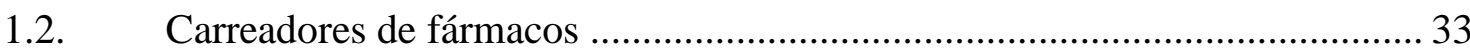

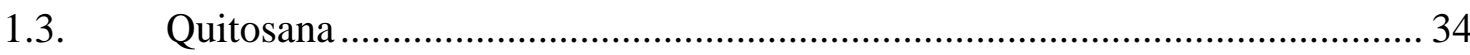

1.4. Derivados de quitosana............................................................................... 36

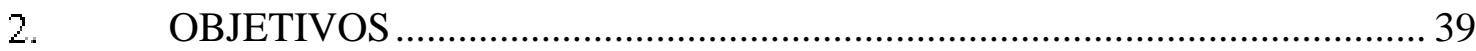

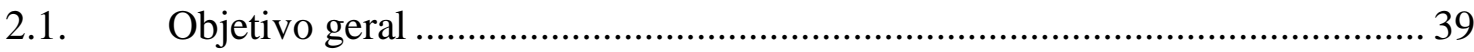

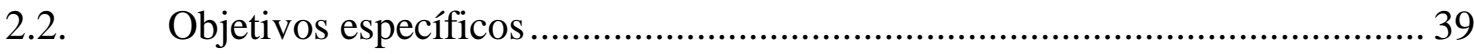

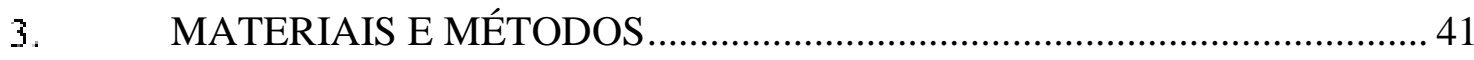

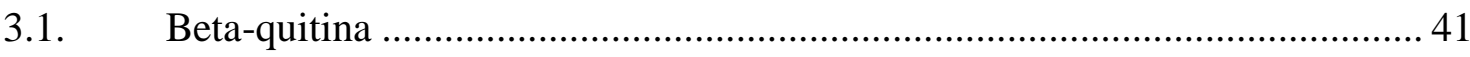

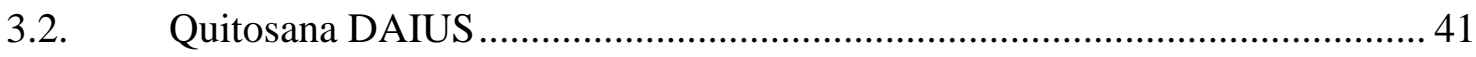

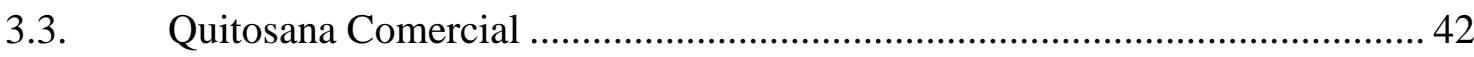

3.4. Síntese de 3,6-O,O'- dimiristoilquitosana ......................................................... 43

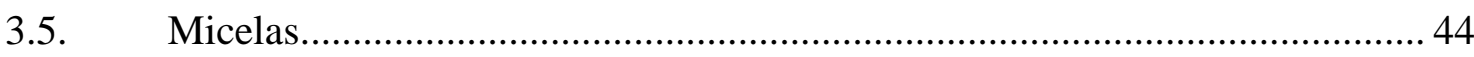

3.5.1. Paclitaxel (PTX) ............................................................................... 44

3.5.2. Camptotecina (CPT) ……………………………………………….....

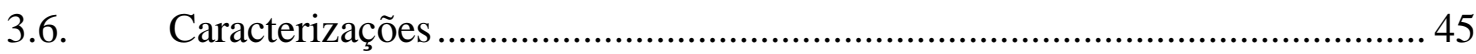

3.6.1. Espectroscopia no infravermelho ....................................................................4

3.6.2. Ressonância magnética nuclear de hidrogênio $\left(\mathrm{RMN}^{1} \mathrm{H}\right)$..................................46

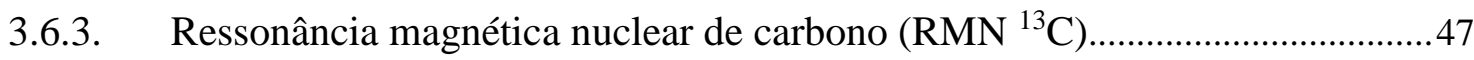

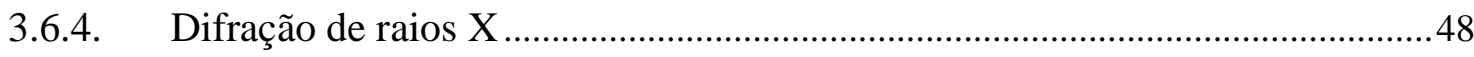

3.6.5. Teste de Solubilidade ……………………………………………………….......49

3.6.6. Termogravimetria.................................................................................. 49

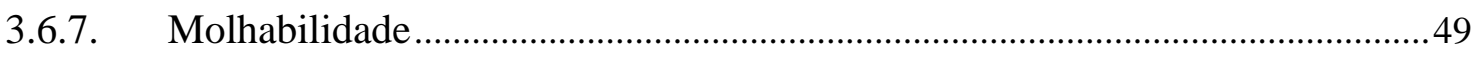

3.6.8. Concentração de agregação crítica (CMC) ...........................................................50 


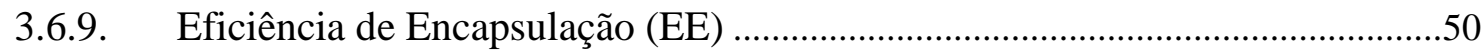

3.6.10. Validação do método segundo ANVISA …...........................................................51

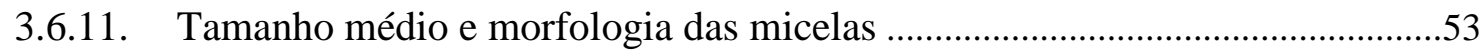

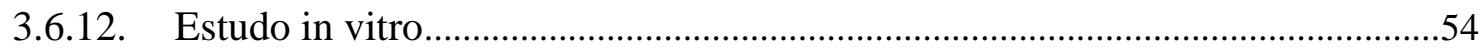

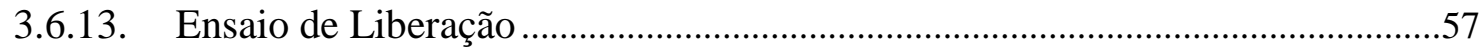

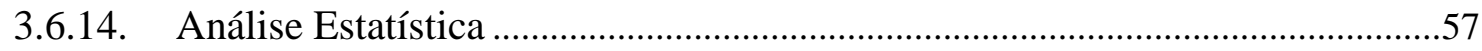

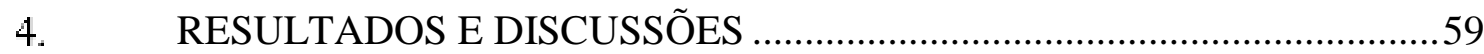

4.1. Parte 1: Caracterizações das quitosana e seu derivado $O$-acilado ..................61

4.1.1. Espectroscopia de Ressonância magnética nuclear de hidrogênio ( $\left.\mathrm{RMN}{ }^{1} \mathrm{H}\right) 61$

4.1.2. Espectroscopia de Ressonância magnética nuclear de carbono $\left(\mathrm{RMN}{ }^{13} \mathrm{C}\right)$...63

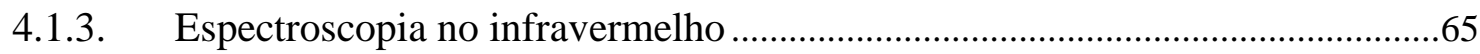

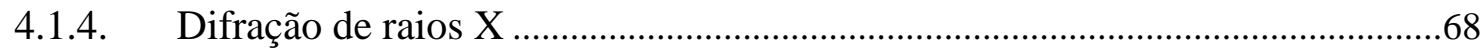

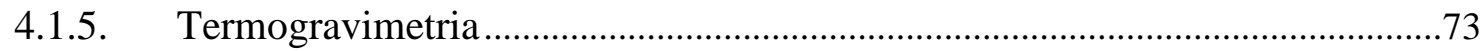

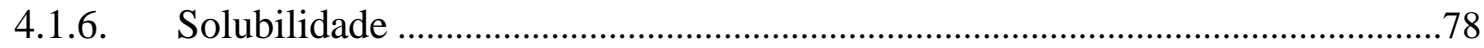

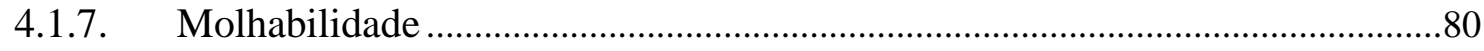

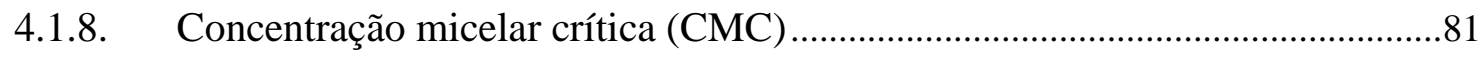

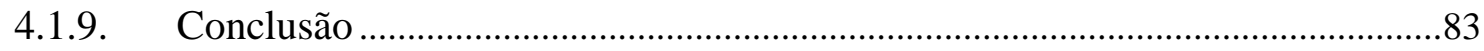

4.2. Parte 2: Estudos de encapsulação e liberação de paclitaxel (PTX).................85

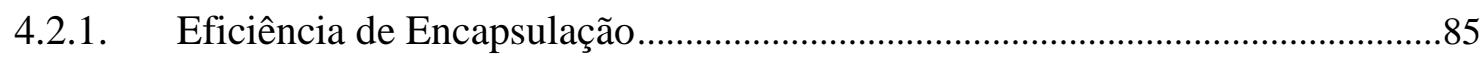

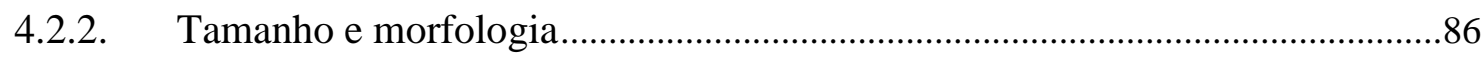

4.2.3. Microscopia Eletrônica de Transmissão (MET) …..............................................92

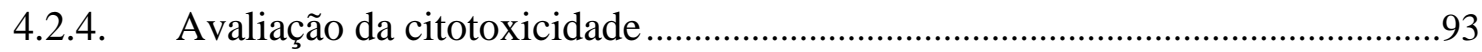

4.2.5. Avaliação da permeabilidade in vitro em monocultura de células Caco-2 e co-

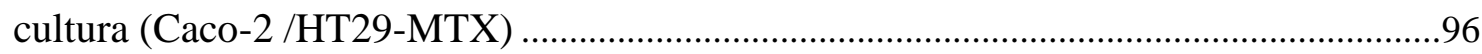

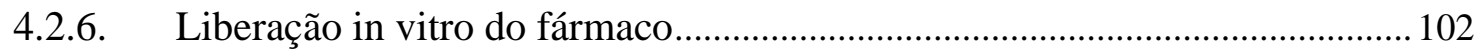

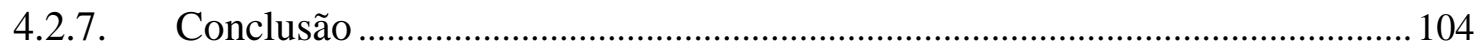

4.3. Parte 3: Estudos de encapsulação e liberação de camptotecina (CPT) ............... 105 


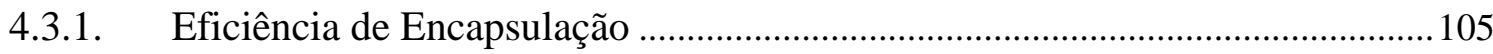

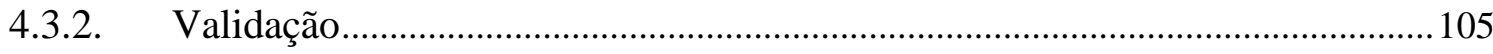

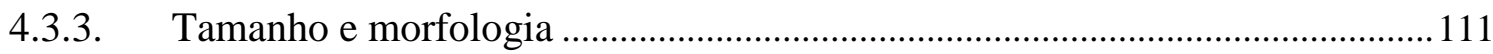

4.3.4. Microscopia Eletrônica de Transmissão (MET) …………………...................... 113

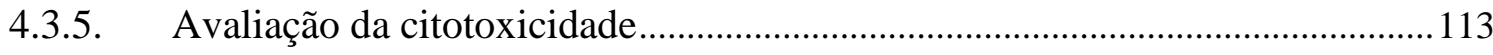

4.3.6. Avaliação da permeabilidade in vitro em monocultura de células Caco-2 e co-

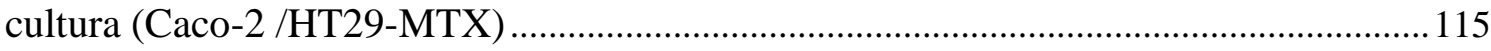

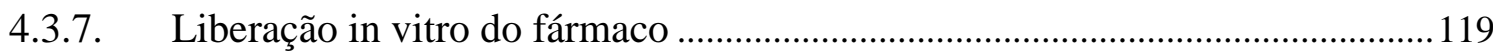

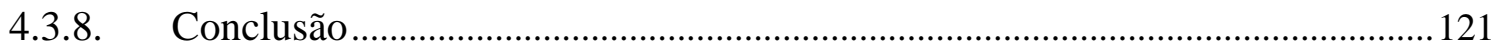

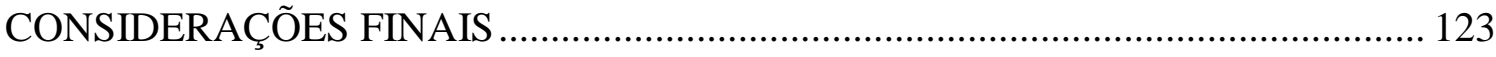

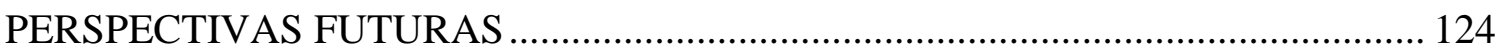

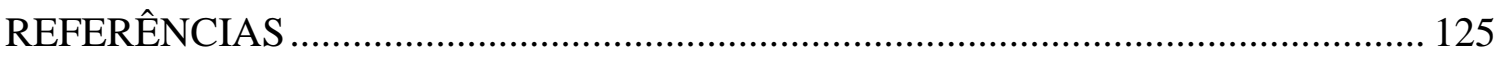

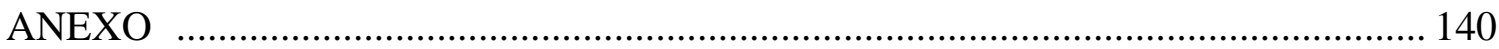

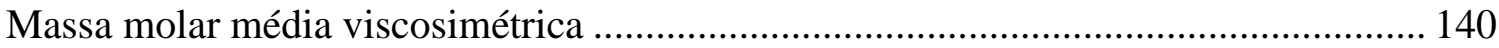





\section{INTRODUÇÃ̃O}

De acordo com Agência Internacional para Pesquisa em Câncer (International Agency for Research on Cancer, IARC), da Organização Mundial da Saúde (OMS), o câncer é uma das principais causas de óbito mundial. Informações sobre o impacto do câncer no Brasil são registradas pelo RCBP- Câncer de Base Populacional, e segundo a atual situação, o Brasil necessita de planejamento e avaliações sobre a ação de controle do câncer. Dados divulgados em 2012 pelo Instituto Nacional do Câncer (INCA), revelam um aumento de 14,1 milhões de novos casos de câncer, acarretando em um total de 8,2 milhões de mortes em todo o mundo (BRAY et al., 2013; MINISTÉRIO DA SAÚDE, 2014). A estimativa para o Brasil no biênio 2016-2017 aponta a ocorrência de cerca de 600 mil novos casos (INSTITUTO NACIONAL DE CANCER JOSÉ ALENCAR GOMES DA SILVA, 2016).

O câncer é uma doença caracterizada pelo crescimento desordenado e descontrolado de células, que estão relacionadas ao termo neoplasia, tumores do tipo maligno. $\mathrm{O}$ desenvolvimento dessa enfermidade pode afetar pessoas de todas as faixas etárias, no entanto, pessoas com idade avançada se enquadram no grupo de risco (DE ALMEIDA et al., 2005; BRANDÃO et al., 2010).

Dentre os diferentes tipos de cânceres, o câncer de cólon está entre os três tipos de tumores malignos mais comuns e está associado a um alto índice de mortalidade, representando mais de 1,4 milhões de novos casos e mais de meio milhão de mortes em todo o mundo. Atualmente as abordagens terapêuticas para o tratamento desse tipo de câncer incluem cirurgias, quimioterapia e radioterapia (XIAO et al., 2015).

A quimioterapia utiliza diversos agentes químicos, geralmente, administrados por via intravenosa. (AGNIHOTRI; MALLIKARJUNA; AMINABHAVI, 2004; MISHRA; PATEL; 
TIWARI, 2010). De acordo com os estudos relacionados ao tratamento de câncer, a quimioterapia continua sendo uma das principais opções terapêuticas para a maioria dos cânceres (O’NEILL; TWELVES, 2002; FERLAY et al., 2010; HALFDANARSON; JATOI, 2010; JEMAL et al., 2010; BRAY et al., 2013; VAN NAGELL et al., 2013; MINISTÉRIO DA SAÚDE, 2014; INSTITUTO NACIONAL DE CANCER JOSÉ ALENCAR GOMES DA SILVA, 2016). Contudo, agentes anticancerígenos tem apresentado algumas limitações e dentre elas destacam-se os efeitos secundários associados às formulações com baixa solubilidade em água, distribuição não específica e alta toxicidade a células sadias (GAO et al., 2014; MULEY et al., 2016). No entanto, a maioria dos agentes usados na quimioterapia tem atuação não específica, podendo lesionar células malignas e saudáveis. Sendo assim, o uso clínico desses agentes químicos deve levar em conta os benefícios que propiciam mas também suas toxicidades, de maneira que o tratamento seja eficiente e seguro (DE ALMEIDA et al., 2005).

No sentido de solucionar a problemática que envolve a atuação dos agentes químicos anticancerígenos, nos últimos 50 anos cerca de 70 novos medicamentos têm sido alvos de estudos e dentre esses a descoberta de novos agentes anticancerígenos tem sido de origem vegetal e o incentivo para os estudos destes tem sido crescente.

\subsection{Anticancerígenos derivados de plantas}

Entre os anos de 1960 e 1982 cerca de 35 mil amostras de origem vegetal foram estudadas. Dentre os possíveis agentes terapêuticos anticancerígenos estudados a descoberta mais relevante foi a do paclitaxel, isolado a partir da casca do Teixo (Taxus baccata L. e Taxus brevifolia Nutt), descoberto em 1971. Comercialmente o paclitaxel (Figura 1) é vendido como Taxol, sendo que a licença para sua comercialização pertence a Bristol-Myers Squibb, empresa que possui o contrato de exclusividade de colheita do Teixo do Pacifico, nos Estados Unidos. Sabe-se que para obtenção de $1 \mathrm{Kg}$ de Taxol é preciso em média 3 mil árvores, sendo o Teixo 
é uma árvore de crescimento lento. No tratamento de um único paciente é necessário o corte e o processamento de 6 árvores de 100 anos (SINGLA; GARG; AGGARWAL, 2002).

Figura 1: Fórmula estrutural do paclitaxel.

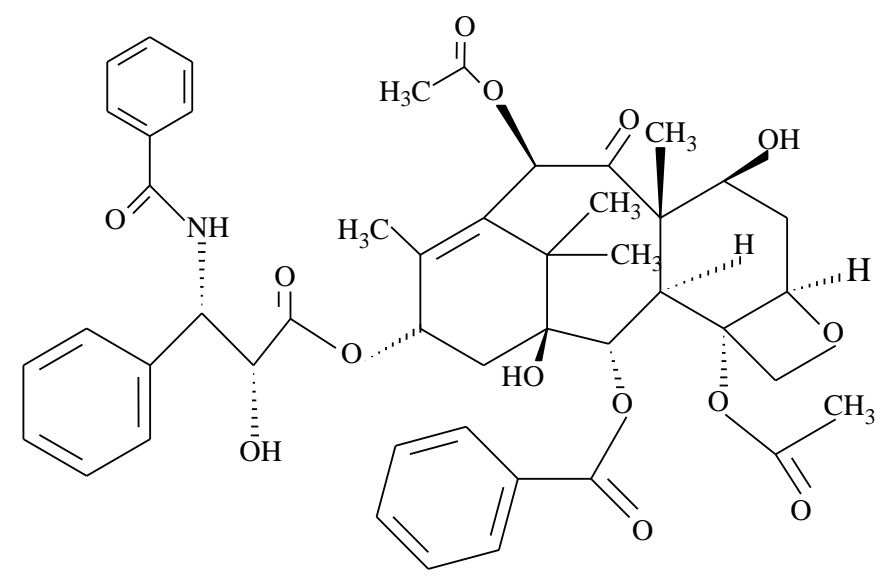

Fonte: Autoria própria.

O paclitaxel (PTX) é um pseudoalcalóide de fórmula molecular $\mathrm{C}_{47} \mathrm{H}_{51} \mathrm{NO}_{14}$, massa molar de $853 \mathrm{Da}$, solubilidade em meio aquoso $<1 \mu \mathrm{gmL}^{-1}$, solúvel em dimetilsulfoxido (DMSO), metanol e etanol, sendo que sua estrutura é rapidamente destruída em soluções alcalinas (HUININK et al., 1997; PANCHAGNULA, 1998; BRANDÃO et al., 2010). PTX foi o primeiro agente anticancerígeno de uma nova classe de agentes estabilizadores de microtúbulos, considerado o maior avanço na quimioterapia nos últimos anos.

O PTX atua como um promotor da polimerização da tubulina e estabilizante dos microtúbulos. As células eucarióticas são compostas por microtúbulos, que estão envolvidos em diversas funções celulares, tais como, mitose, manutenção da forma celular, mobilidade e o transporte entre as organelas no interior das células (HUININK et al., 1997; PANCHAGNULA, 1998; SINGLA; GARG; AGGARWAL, 2002). Portanto, o PTX é capaz de alterar o equilíbrio da tubulina e dos microtúbulos, pois se liga à proteína tubulina dos microtúbulos e os mantêm fixos e, consequentemente interrompe a divisão celular através da estabilização dos microtúbulos, que interferem nas fases $\mathrm{G} 2$ e $\mathrm{M}$ do ciclo celular, inibindo o processo de 
replicação das células (Figura 2). O complexo resultante da interação dos microtúbulos com o paclitaxel é extremamente estável (PANCHAGNULA, 1998; SINGLA; GARG; AGGARWAL, 2002; DE ALMEIDA et al., 2005).

Figura 2: Mecanismo de ação do paclitaxel.

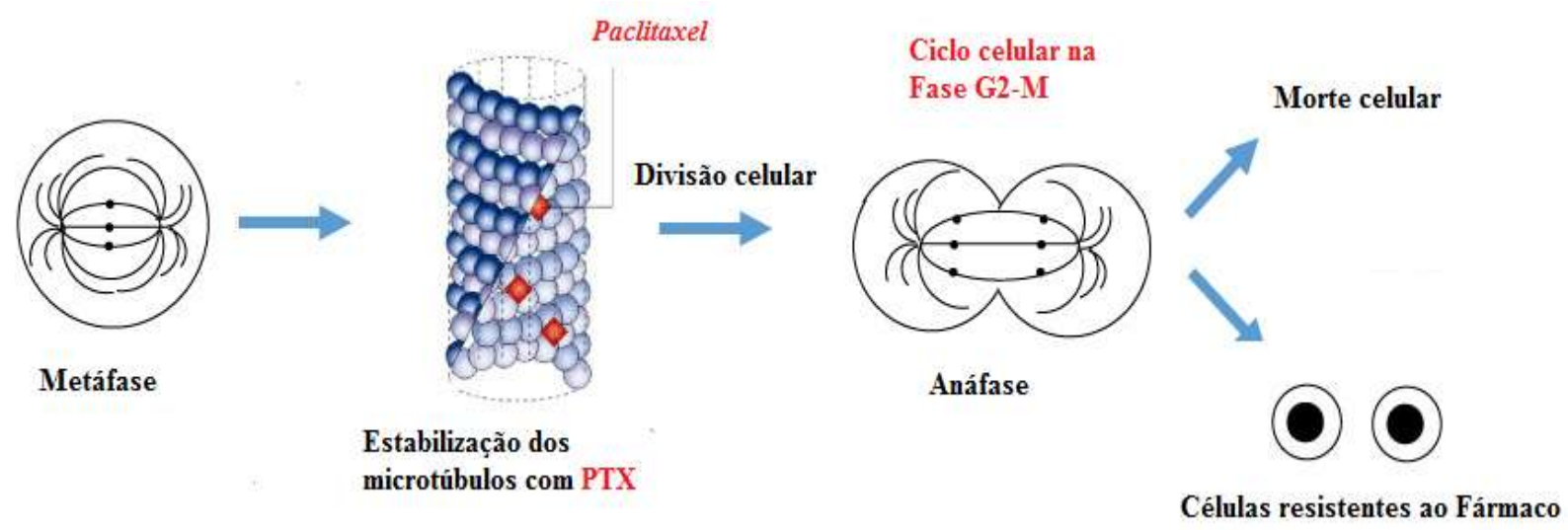

Fonte: Adaptada-(DE SOUZA, 2004).

Atualmente, na versão comercializada Taxol ${ }^{\circledR}$, o PTX é solubilizado na mistura 50:50 Cremophor $\mathrm{El}^{\circledR}$ e etanol desidratado. No entanto, o agente solubilizante Cremophor $\mathrm{El}^{\circledR}$ está $^{\circledR}$ associado a efeitos adversos, tais como, reações anafiláticas, hiperlipidemia, agregação dos eritrócitos, hemólise e neuropátia periférica (YOU et al., 2007; MO et al., 2011; NAM et al., 2013; SARISOZEN; ABOUZEID; TORCHILIN, 2014; MULEY et al., 2016). Sendo assim, há a necessidade de desenvolver carreadores não-tóxicos para entrega de PTX, que promovam a solubilização do fármaco, protejam contra degradação, diminuam a toxicidade e aumentem a biodisponibilidade.

Outro agente quimioterapêutico de origem vegetal amplamente estudado é a camptotecina (CPT), isolada pela primeira vez em 1958, sendo sua estrutura química descoberta em 1966. A CPT (Figura 3) é um alcalóide encontrado na casca da Camptotheca acuminata, árvore nativa da China, fórmula molecular $\mathrm{C}_{20} \mathrm{H}_{16} \mathrm{~N}_{2} \mathrm{O}_{4}$, massa molar de 348,4 Da, solúvel em DMSO (10 mg/mL) (KACPRZAK, 2013). 
Figura 3: Fórmula estrutural da camptotecina.

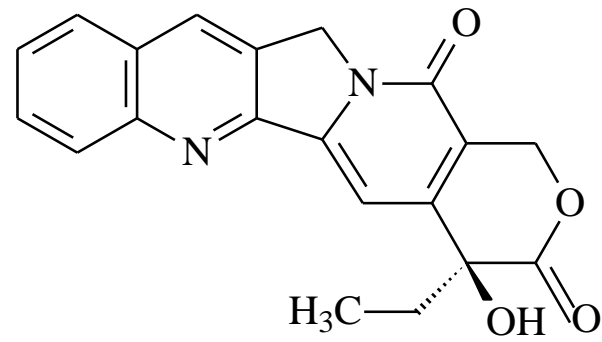

Fonte: Autoria própria.

A camptotecina apresenta aplicação limitada devido à baixa solubilidade em meio aquoso, alta toxicidade e à inativação do seu anel lactona, devido à elevada reatividade do grupo $\alpha$-hidroxicarbonilo. De fato, quando expostos a condições de $\mathrm{pH}$ fisiológico $(\mathrm{pH} 7,4), \mathrm{o}$ anel de lactona da CPT pode sofrer hidrólise, e estabelecer o equilíbrio (Figura 4) lactona/ ácido carboxílico (GAO et al., 2008; KOLHATKAR; SWAAN; GHANDEHARI, 2008; CONCHEIRO, 2010; LASKAR et al., 2014).

Figura 4: Equilíbrio lactona-ácido carboxílico em diferente $\mathrm{pH}$.<smiles>CC[C@@]1(O)C(=O)OCc2c1cc1n(c2=O)Cc2cc3ccccc3nc2-1</smiles>

Lactona (Ativa)

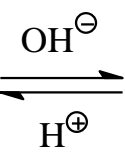

Fonte: Autoria própria.<smiles>CC[C@@](O)(C(=O)[O-])c1cc2n(c(=O)c1CO)Cc1cc3ccccc3nc1-2</smiles>

Ácido carboxílico (Inativo)

A forma ácido carboxílico da CPT é farmacologicamente ineficaz e é responsável pela ocorrência de efeitos tóxicos, tais como mielossupressão, cistite hemorrágica e diarreia. Além disso, alguns estudos relatam que a forma carboxilato da CPT tem afinidade elevada com a 
albumina do soro humano, o que provoca o deslocamento do equilíbrio na direção da forma carboxílica (MI; BURKE, 1994; OPANASOPIT et al., 2005).

O mecanismo de ação da CPT (Figura 5) consiste da interrupção do processamento do DNA pela enzima topoisomerase I, composto relacionado estruturalmente à formação do complexo covalente DNA-topoisomerase I, sendo que a CPT se liga reversivelmente ao complexo, mas não à enzima ou DNA isolado, e assim perturba o conjunto de equilíbrios, resultando na clivagem do DNA, que leva à apoptose (morte celular) (HERTZBERG; CARANFA; HECHT, 1989; CONCHEIRO, 2010; KACPRZAK, 2013; LUO et al., 2013; GONZALEZ-ALVAREZ et al., 2014).

Figura 5: Mecanismo de ação da camptotecina.

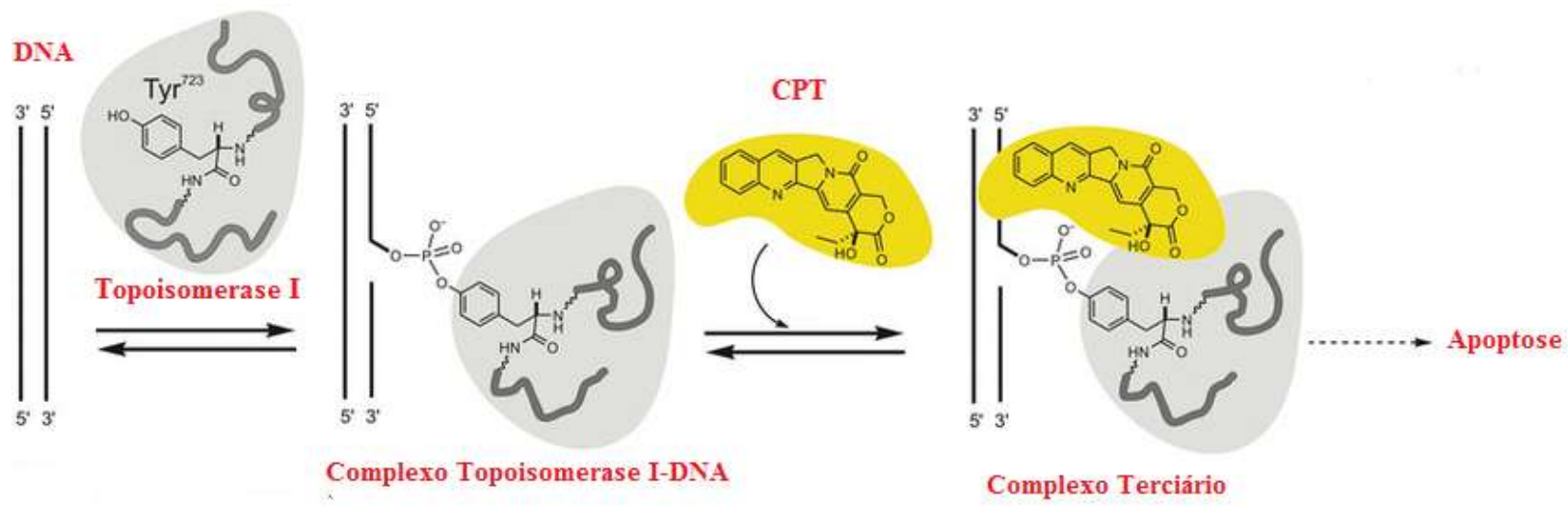

Fonte: Adaptada- (KACPRZAK, 2013).

No entanto, mesmo com a descoberta e o conhecimento do mecanismo de atuação dos fármacos PTX e CPT, estes ainda apresentam limitações devido à baixa solubilidade dos mesmos, sendo assim diferentes grupos de pesquisa estão continuamente à procura de formulações e terapias que possam atuar seletivamente em células tumorais com efeitos colaterais mínimos sobre os pacientes (KWON; OKANO, 1996; YE et al., 2008; EBRAHIM ATTIA et al., 2011; CHO; KIM; PARK, 2012). Portanto, novas abordagens são necessárias para a entrega específica de agentes quimioterapêuticos a células tumorais (XIE et al., 2016). 


\subsection{Carreadores de fármacos}

Atualmente a maioria dos fármacos utilizados no tratamento de câncer a partir da quimioterapia são administrados por via intravenosa. No entanto, sabe-se que estes agentes não atuam de forma específica, desta forma afetam o metabolismo das células saudáveis, apresentam toxicidade e prejudicam a qualidade de vida do paciente (GAO et al., 2014).

A administração via oral é considerada a rota mais conveniente para administração de fármaco, devido à facilidade de adesão ao tratamento (BORNER et al., 2001; O'NEILL; TWELVES, 2002). Contudo, para que haja uma administração oral bem-sucedida é necessário que o carreador do fármaco resista ao ataque de enzimas e também ao impacto dos gradientes de $\mathrm{pH}$ desde o estômago ( $\mathrm{pH}$ 1-3) ao intestino (pH 6-7), sendo que o tempo gasto para o trânsito gastrointestinal para administração oral é de aproximadamente 16 horas (O’NEILL; TWELVES, 2002; GUO; GAO, 2007; HALFDANARSON; JATOI, 2010; ROGER et al., 2010).

Adicionalmente, agentes quimioterapêuticos administrados via oral podem apresentar biodisponibilidade variável ou até mesmo limitada, devido à baixa solubilidade do fármaco, instabilidade da molécula ativa no trato gastrointestinal, absorção restrita e baixa permeabilidade (HALFDANARSON; JATOI, 2010; LIU et al., 2013; TAVARES, 2013). Neste contexto, a evolução dos estudos na área de biotecnologia farmacêutica levou ao desenvolvimento de novas formulações, dentre as quais se destacam sistemas baseados em lipossomas e micelas (MARTIN et al., 2002).

Apesar de já se encontrarem no mercado diversas formulações lipossômicas, nos últimos anos os sistemas à base de micelas, especialmente as micelas poliméricas, têm sido alvo de intensa investigação, com diversas formulações em fase de ensaios clínicos, principalmente em decorrência da sua capacidade de encapsular tanto fármacos hidrofóbicos como hidrofílicos, em função da natureza dos polímeros empregados. Além disso, os sistemas à base de micelas 
poliméricas apresentam maior estabilidade física e eficiência de encapsulação comparativamente aos lipossomas (LE TIEN et al., 2003'ISHIHARA et al., 2012).

Em especial, micelas poliméricas do tipo shell/core exibem muitas vantagens com relação à encapsulação e liberação controlada de fármacos, pois seus núcleos hidrofóbicos (core) promovem a solubilização de ativos hidrofóbicos, evitando a degradação do fármaco, enquanto que suas cascas exteriores hidrofílicas (shell) evitam o reconhecimento pelo sistema imune, prolongando o tempo de circulação do fármaco no organismo (CONCHEIRO, 2010; EBRAHIM ATTIA et al., 2011; BEI et al., 2014; WORAPHATPHADUNG et al., 2016). Assim, as micelas poliméricas têm sido consideradas como promissores transportadores de moléculas bioativas, inclusive medicamentos insolúveis em água, hormônios e plasmídeos (YAO et al., 2007).

Nas últimas décadas, sistemas micelares à base de copolímeros em blocos têm sido explorados para encapsulação/liberação de fármacos, especialmente nos casos de fármacos insolúveis em água. No entanto, o desenvolvimento industrial desses sistemas ainda é muito limitado devido às dificuldades de preparo e aos altos custos (EBRAHIM ATTIA et al., 2011). Com intuito de evitar as dificuldades encontradas no preparo de copolímeros, a quitosana tem sido considerada um agente promissor para aplicações potenciais na área biomédica e farmacêutica (EBRAHIM ATTIA et al., 2011,JIANG et al., 2006b).

\subsection{Quitosana}

A quitosana tem sido considerada um agente promissor para aplicações potenciais em áreas biomédica e farmacêutica, uma vez que é um biopolímero catiônico que exibe atividades biológicas interessantes, tais como biocompatibilidade, biodegradabilidade, mucoadesividade, propriedades antimicrobianas e antioxidantes, e é suscetível de ser quimicamente modificada, 
permitindo a funcionalização de superfícies carreadoras de fármaco (JIANG et al., 2006a, 2006b; EBRAHIM ATTIA et al., 2011).

A quitosana, é um biopolímero, que ocorre nas paredes celulares de alguns fungos e leveduras, constituído por unidades 2-acetamido-2-desoxi-D-glicopiranose (GlcNAc) e 2amino-2-desoxi-D-glicopiranose (GlcN), unidas por ligações glicosídicas do tipo $\beta(1 \rightarrow 4)$, com predomínio de unidades GlcN (Figura 6) (CAMPANA-FILHO, S. P. et al., 2007). É produzido industrialmente e em laboratórios de pesquisa via $N$-desacetilação de quitina. A presença de grupos animo e hidroxila em suas unidades estruturais oferece muitas possibilidades de modificações químicas, o que permite melhorar as propriedades do polímero de partida e/ou introduzir novas propriedades interessantes (BADAWY et al., 2004).

Figura 6: Representação da estrutura primária idealizada de quitosana, onde n é o grau médio de polimerização.

\section{QUITOSANA}

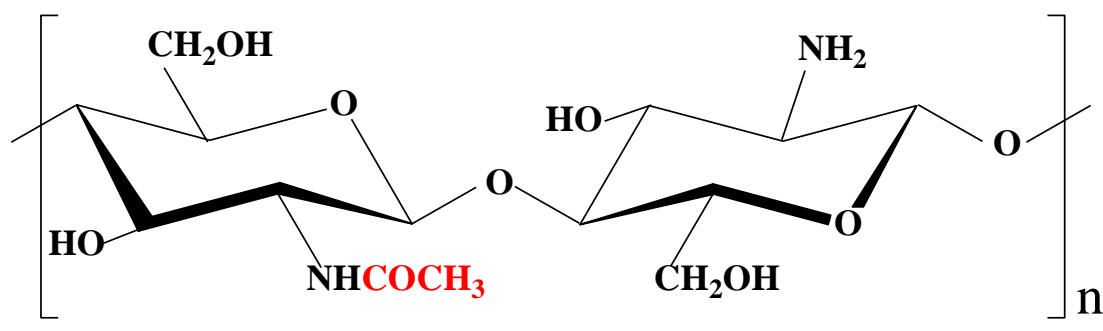

Fonte: Autoria própria.

De fato, a quitosana e, também seus derivados, têm sido foco de estudos visando à encapsulação e liberação controlada de fármacos desde meados de 1990 (PHILIPPI et al., 2012), visto que podem ser processados como filmes, soluções poliméricas e sistemas nanopartículados e, principalmente, porque apresentam a capacidade de abrir temporariamente as estreitas junções intracelulares do epitélio intestinal, facilitando assim a permeação de fármacos (UCHEGBU et al., 2014). 
Adicionalmente, a modificação química da quitosana permite a obtenção de derivados que podem ser usados como carreadores de fármacos através de várias vias de administração, levando a resultados promissores (LEITHNER; BERNKOP-SCHN, 2012).

\subsection{Derivados de quitosana}

As mudanças estruturais propostas para quitosana visam melhorar propriedades tais como solubilidade, capacidade de intumescimento, complexação de cátions metálicos, interação com outros polímeros, enzimas, proteínas e substâncias orgânicas. As reações de derivatização da quitosana são usualmente realizadas sob condições brandas, evitando assim a ruptura de ligações glicosídicas e a hidrólise dos grupos acetamido (RINAUDO, 2006).

Para melhorar a capacidade de carga de fármaco e com intuito de encapsular fármacos hidrofílicos e hidrofóbicos, quer isolados ou combinados, podem ser utilizados derivados anfifílicos de quitosana. Quitosana hidrofobicamente modificada com adição de grupos acila de cadeia longa tem sido utilizada para obter nanopartículas como um sistema de entrega de fármacos para câncer, com resultados promissores em relação à inibição do crescimento do tumor (BALAN; BUTNARU; VERESTIUC, 2013).

Deste modo, diferentes derivados anfifílicos de quitosana têm sido propostos como veículos de fármacos hidrofóbicos, tais como ácido $N$ - (2,3-dihidroxipropil) -quitosana-cólico (PAN et al., 2013), quitosana enxertada com polilactida (PLA) (DI MARTINO; SEDLARIK, 2014), $N$-octil- $N$-trimetilquitosana (ZHANG et al., 2007), $N$-propil- $N$-metileno fosfônico quitosana (ZUÑIGA et al., 2010), oligossacarídeo de quitosana enxertada com ácido esteárico (YE et al., 2008), $N$-naftil- $N, O$-succinil quitosana, $N$-octil- $N$, $O$-succinil quitosana e $N$-benzil$N$, $O$-succinil quitosana (WORAPHATPHADUNG et al., 2016).

Neste trabalho, um derivado anfifílico de quitosana, a saber $O, O^{\prime}$-dimiristoilquitosana, foi escolhido para o desenvolvimento de sistemas micelares visando à encapsulação/liberação 
de fármacos hidrofóbicos empregados no tratamento de câncer de colón retal. Assim, a natureza anfifílica desse derivado de quitosana se deve à introdução dos grupos acila de cadeia longa, conferindo caráter hidrofóbico ao polímero, e à preservação de grupos amino das unidades 2amino-2-desoxi-D-glicopiranose da quitosana de partida, que conferem características hidrofílicas (TONG et al., 2005)’(LE TIEN et al., 2003).

O adequado balanço hidrofilicidade / hidrofobicidade pode ser alcançado através do controle do grau médio de substituição $(\overline{G S})$ de 3,6-O,O'-dimiristoilquitosana, de maneira a favorecer a produção de micelas poliméricas dotadas de núcleos hidrofóbicos, eficientes para o encapsulamento de pequenas moléculas hidrofóbicas em meio moderadamente ácido, enquanto que o caráter hidrofílico da superfície externa das micelas confere compatibilidade com meios biológicos (MIWA et al., 1998).

Neste estudo foi preparado um derivado anfifílico de quitosana pouco estudado e foi explorada a sua capacidade de auto-micelização visando o desenvolvimento de sistemas para encapsular PTX e CPT. As principais características físico-químicas das micelas resultantes, incluindo concentração crítica de agregação (CAC), tamanho médio, potencial zeta, eficiência de encapsulação e o perfil de liberação dos fármacos foram determinadas. A toxicidade das micelas carregadas com PTX e CPT in vitro foram avaliadas utilizando as linhas celulares Caco2 (clone C2BBe1) e HT29-MTX, enquanto no ensaio de permeabilidade foram utilizados os modelos de monocultura Caco-2 e de co-cultura Caco-2 / HT29-MTX. Portanto, foi realizado o estudo in vitro das micelas desenvolvidas para promover a absorção oral dos fármacos anticancerígenos. 


\section{OBJETIVOS}

\subsection{Objetivo geral}

Com o crescente interesse na produção de derivados anfifílicos de quitosana, este trabalho teve como objetivo a produção de 3,6-O, $O^{\prime}$-dimiristoilquitosana, derivado de quitosana ainda pouco estudado e que possui grupos amino disponíveis, visando aliar às características hidrofílicas da quitosana de partida e o caráter hidrofóbico dos substituintes miristoíla, conferindo ao produto final a capacidade de auto-micelização, explorada para encapsulação fármacos hidrofóbicos para administração via oral.

\subsection{Objetivos específicos}

- Sintetizar e caracterizar diferentes derivados de quitosana 3,6-O, $O^{\prime}$-dimiristoilquitosana;

- Encapsular os fármacos PTX e CPT e caracterizar com relação as suas propriedades físico-químicas, morfológicas e biológicas (in vitro);

- Realizar o estudo de liberação in vitro;

- Quantificar os fármacos modelos presentes nos sistemas micelares;

- Avaliar a citotoxicidade das micelas vazias e carregadas com os fármacos;

- Quantificar os fármacos (CPT e PTX) nos ensaios de permeabilidade in vitro para os modelos de monocultura e co-cultura por cromatografia líquida de alta eficiência. 


\section{MATERIAIS E MÉTODOS}

Os reagentes e solventes utilizados neste trabalho foram de grau técnico ou para análise e foram usados conforme recebidos.

\subsection{Beta-quitina}

A beta-quitina foi extraída de gládios de lulas (Doryteuthis spp.) cedidos pela Empresa Miami Pescados (Cananéia/SP). Para extração da beta-quitina foi realizado apenas o processo de desproteinização, devido à essa biomassa apresentar baixíssimo teor de minerais e não apresentar pigmentos (CAMPANA-FILHO et al., 2007; DELEZUK et al., 2011; BIROLLI; DELEZUK; CAMPANA-FILHO, 2016). Assim, foram suspensos 200g de gládios moídos $(250 \mu \mathrm{m}-425 \mu \mathrm{m})$ em $3 \mathrm{~L}$ de solução aquosa de $\mathrm{NaOH} 0,1 \mathrm{~mol} \mathrm{~L}^{-1}$. A suspensão foi mantida sob agitação magnética, durante 18 horas a $25^{\circ} \mathrm{C}$. Em seguida, a suspensão foi filtrada e o sólido lavado com água destilada até a neutralidade das águas de lavagem. A beta-quitina foi transferida para placas de Petri e seca em estufa com circulação e renovação de ar durante 24 horas, a 30 C (SIGNINI; CAMPANA FILHO, 2001; CAMPANA-FILHO et al., 2007).

\subsection{Quitosana DAIUS}

A beta-quitina obtida dos gládios de lulas foi submetida ao processo de desacetilação assistida por irradiação de ultrassom de alta intensidade (DAIUS), com objetivo de obter quitosana com baixo grau médio de acetilação e alta massa molar média. Em um reator encamisado acoplado ao banho de circulação (Thermo Scientific, modelo Hooke A10), foi adicionada uma suspensão de 4,4g de quitina, em $50 \mathrm{~mL}$ de solução aquosa $40 \%$ de $\mathrm{NaOH}$. O sonotrodo H22 acoplado ao dispositivo ultrassônico (Hielscher modelo UP400S, $v=24 \mathrm{kHz}$ ) foi imerso (aproximadamente $2 / 3$ do comprimento) na suspensão de quitina, a qual foi mantida 
sob agitação magnética por 50 minutos, amplitude de irradiação média $\left(30 \%<\mathrm{A}_{\text {máx }}<50 \%\right)$, à temperatura de $65 \pm 2{ }^{\circ} \mathrm{C}$. A reação foi interrompida pela adição da suspensão em um béquer de polipropileno contendo cubos de gelo de água destilada. A suspensão foi mantida à baixa temperatura enquanto foi adicionado $\mathrm{HCl}(\mathrm{PA})$, em pequenas porções, até atingir $\mathrm{pH} \approx 7-8$. Em seguida, a suspensão foi filtrada e o sólido lavado com etanol 80\%, para eliminar o excesso de cloreto de sódio. O sólido foi transferido para placa de Petri e seco em estufa de circulação a $30^{\circ} \mathrm{C}$ por 48 horas e em estufa de vácuo, a $30^{\circ} \mathrm{C}$, por 24 horas.

O procedimento de desacetilação assistida por irradiação de ultrassom de alta intensidade (DAIUS) foi aplicado mais 1 vez sobre o produto da primeira reação para resultar na quitosana DAIUS (QD) $\operatorname{com} \overline{G A}=5 \%$ e $\overline{M v}=300 \mathrm{kDa}^{1}$.

\subsection{Quitosana Comercial}

A quitosana comercial (QC) $\operatorname{com} \overline{G A}=15 \%$ e $\overline{M v}=87 \mathrm{kDa}$, foi adquirida da Cheng Yue Planting Co Ltda (China) e sua purificação foi realizada através da adição de $3 \mathrm{~g}$ de quitosana em 1L de ácido acético 1\% (v/v), e a suspensão foi mantida sob agitação constante por aproximadamente $24 \mathrm{~h}$ à temperatura ambiente. A solução resultante foi filtrada sob pressão positiva através de membrana de porosidade $0,45 \mu \mathrm{m}$ (Millipore-White SCWP). A solução filtrada foi então neutralizada com solução concentrada de $\mathrm{NaOH}\left(1 \mathrm{~mol} \mathrm{~L}^{-1}\right)$, provocando a precipitação da quitosana. O precipitado foi filtrado, lavado com soluções de etanol/água a 75\%, $80 \%$ e $90 \%$ (v/v), etanol absoluto e seco na estufa de circulação, a $30^{\circ} \mathrm{C}$. Após a evaporação de todo etanol, a quitosana foi congelada e liofilizada.

\footnotetext{
${ }^{1}$ Metodologia empregada para determinação de $\overline{M v}$ da quitosana DAIUS e comercial está na seção de anexo.
} 


\subsection{Síntese de 3,6-O,O'- dimiristoilquitosana}

As amostras de 3,6-O,O'- dimiristoilquitosana foram sintetizadas baseando-se no procedimento descrito por Tong e colaboradores (TONG et al., 2005), conforme a reação apresentada na Figura 7. Aproximadamente 1g de quitosana (QD ou QC) foi solubilizada em $25 \mathrm{~mL}$ de ácido metanossulfônico $\left(\mathrm{MeSO}_{3} \mathrm{H}\right)$ e a solução ficou sob agitação constante por $1 \mathrm{~h}$ a $25^{\circ} \mathrm{C}$, em balão vedado por septo. Em seguida, o cloreto de miristoila $(\mathrm{CM})$ foi adicionado à solução de quitosana de maneira a resultar na razão molar Q/CM desejada. A adição do cloreto de miristoila foi feita em aproximadamente 10 minutos, a reação procedeu por 1 hora a $25^{\circ} \mathrm{C} \mathrm{e}$ foi interrompida quando o meio reacional foi vertido em $500 \mathrm{~mL}$ de água destilada e gelo, resultando na precipitação do produto. O precipitado foi filtrado em funil de Buchner, lavado por agitação com bicarbonato de sódio 5\%, centrifugado, lavado com água deionizada até que a água de lavagem atingisse $\mathrm{pH} \approx 7,0$ e em seguida foi liofilizado. Após a liofilização o derivado 3,6-O,O’-dimiristoilquitosana (QDM) foi extraído com clorofórmio em Soxhlet por 24h e em seguida seco na estufa de circulação a $30^{\circ} \mathrm{C}$.

Figura 7: Esquema reacional da síntese dos derivados 3,6- $O, O^{\prime}$ - dimiristoilquitosana.

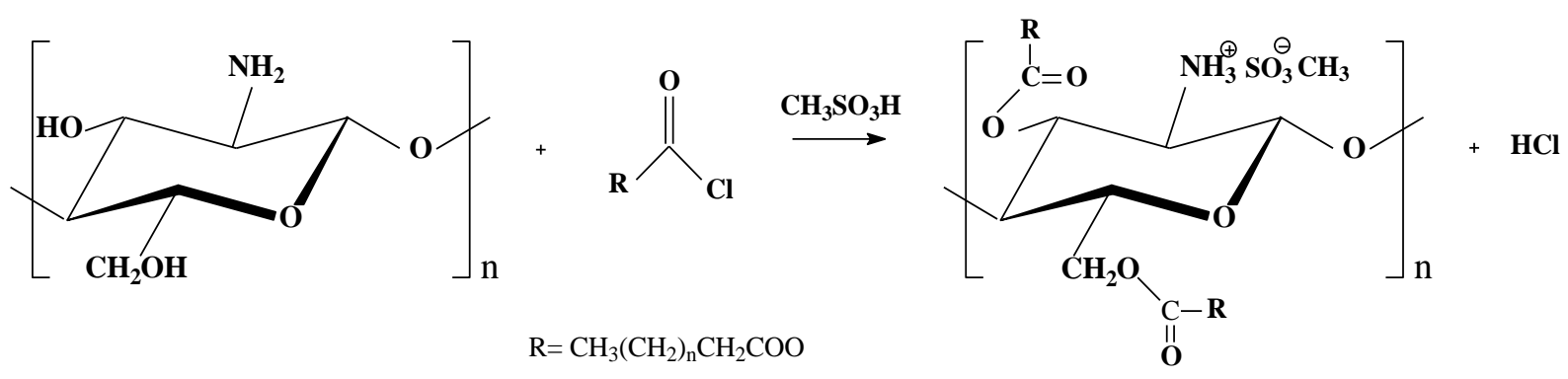

Nas sínteses do derivado 3,6-O,O’- dimiristoilquitosana (QDM) foram empregadas as amostras de quitosana comercial (QC) e quitosana DAIUS (QD) e diferentes razões molares quitosana/cloreto de miristoil (Q/CM), a saber 1:0,075; 1:0,1; 1:0,2 e 1:0,5. A identificação das amostras dos derivados QDM conforme a quitosana de partida e as razões molares empregadas na reação de $O$-acilação é mostrada na Tabela 1. 
Tabela 1: Amostras de 3,6- $O, O^{\prime}$-dimiristoilquitosana preparadas a partir de quitosana comercial (QCMx) e de quitosana DAIUS (QDMx) empregando diferentes razões molares quitosana/cloreto de miristoíla

\begin{tabular}{ccc}
\hline $\begin{array}{c}\text { Razão molar } \\
\text { quitosana/cloreto de miristoila }\end{array}$ & QCMx & QDMx \\
\hline $1: 0,075$ & QCM1 & QDM1 \\
$1: 0,1$ & QCM2 & QDM2 \\
$1: 0,2$ & QCM3 & QDM3 \\
$1: 0,5$ & QCM4 & QDM4 \\
\hline
\end{tabular}

\subsection{Micelas}

As micelas produzidas a partir dos derivados QCM1 e QCM4 foram preparadas através do método de evaporação do solvente e carregadas com diferentes fármacos, conforme descrito a seguir e apresentado esquematicamente na Figura 8.

Figura 8: Esquema da obtenção de micelas via evaporação do solvente.

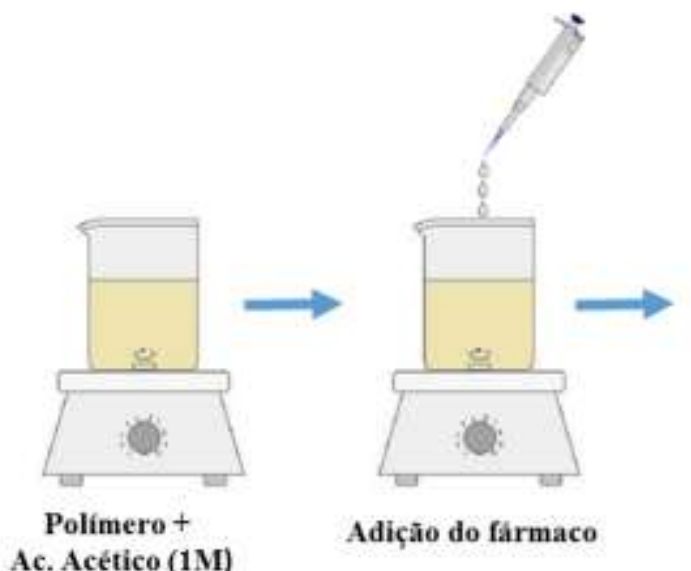

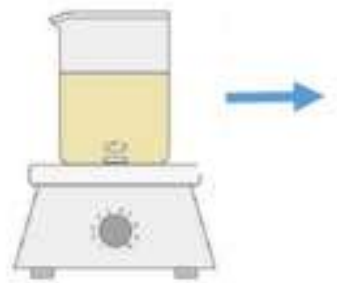

Evaporação do solvente

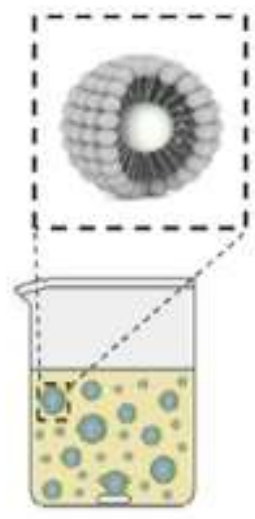

Micelas carregadas com fármaco

Fonte: Adaptada- (MARINA; ALMEIDA, 2016).

\subsubsection{Paclitaxel (PTX)}

Foram dispersos $5 \mathrm{mg}$ do derivado de quitosana (QCM1 ou QCM4) em $5 \mathrm{~mL}$ de ácido acético $0,1 \mathrm{~mol} \mathrm{~L}^{-1}$, para resultar em solução com $\mathrm{Cp}=1 \mathrm{mg} \mathrm{mL}^{-1} \mathrm{O}$ fármaco (PTX) foi solubilizado em etanol a $70 \%$ para resultar em $[\mathrm{PTX}]=1 \mathrm{mg} \mathrm{mL}^{-1}$. As soluções polimérica e de fármaco foram misturadas em diferentes proporções, de modo a resultar em $[\mathrm{PTX}]=5,25,50 \mathrm{e}$ 
$100 \mu \mathrm{g} \mathrm{mL} \mathrm{L}^{-1}$. A completa evaporação do etanol presente nas misturas ocorreu após agitação a 300 rpm, durante 4 horas, a $25^{\circ} \mathrm{C}$. Em seguida, a suspensão micelar foi sonicada durante 5 minutos, usando um sonicador do tipo sonda (Cell Vibra, Sonics material INC. Danbury, EUA), sob banho de gelo. Para remover o fármaco não encapsulado, as soluções foram centrifugadas e filltradas com Amicon® Ultra-15 filtros, com poros de $100 \mathrm{kDa}$, a 5000 rpm durante $10 \mathrm{~min}$ (SILVA et al., 2017).

\subsubsection{Camptotecina (CPT)}

As micelas carregadas com camptotecina foram obtidas através do método de remoção do solvente (DMSO) por liofilização. A solução polimérica foi preparada pela solubilização de $5 \mathrm{mg}$ de QCM1 em ácido acético $0,1 \mathrm{~mol} \mathrm{~L}^{-1}$, resultando em $\mathrm{Cp}=1 \mathrm{mg} \mathrm{mL}{ }^{-1}$. Solução [CPT] $=1 \mathrm{mg} \mathrm{mL} \mathrm{m}^{-1}$ foi preparada pela dissolução de $1 \mathrm{mg}$ de fármaco em $1 \mathrm{~mL}$ dimetilsulfóxido (DMSO). Diferentes volumes de solução de CPT (50, 100 e $150 \mu \mathrm{L})$ foram adicionadas a $5 \mathrm{~mL}$ de solução polimérica e as soluções finais foram mantidas sob agitação magnética de 300 rpm, durante $2 \mathrm{~h}$ a $25^{\circ} \mathrm{C}$, em seguida foram congeladas a $-80^{\circ} \mathrm{C}$ e liofilizadas para remoção total de solvente. Os produtos secos foram ressuspensos em $5 \mathrm{~mL}$ de ácido acético $0,1 \mathrm{~mol} \mathrm{~L}^{-1} \mathrm{e}$ as soluções resultantes foram sonicadas durante $5 \mathrm{~min}$, utilizando um sonicador de tipo sonda (Vibra-cell, Sonics Material Inc. Danbury, EUA), em banho gelado. Finalmente, as soluções foram centrifugadas a $5000 \mathrm{rpm}$ durante $10 \mathrm{~min}$ (Thermo Scientific Heraeus Megafuge 1.0R) para remoção do fármaco não encapsulado.

\subsection{Caracterização}

\subsubsection{Espectroscopia no infravermelho}

Os modos de vibração foram determinados por espectroscopia vibracional na região do infravermelho. Amostra e $\mathrm{KBr}$ (grau espectroscópico), previamente secos na estufa a vácuo a $60^{\circ} \mathrm{C}$ por 8 horas, foram misturados na proporção 1:100 (amostra/KBr), triturados em gral de 
ágata e então foram preparadas pastilhas para a aquisição dos espectros no espectrofotômetro IRAffinity-1 da Shimadzu, com acúmulo de 32 varreduras e resolução de $4 \mathrm{~cm}^{-1}$.

\subsubsection{Ressonância magnética nuclear de hidrogênio $\left(\operatorname{RMN}^{1} \mathbf{H}\right)$}

Os espectros de RMN foram adquiridos nos laboratórios da Central de Análises Químicas do Instituto de Química de São Carlos (CAQI/IQSC), empregando o espectrofotômetro Bruker AVANCE III (400 MHz). A espectroscopia RMN ${ }^{1} \mathrm{H}$ permitiu a caracterização estrutural das amostras geradas neste trabalho e também propiciou a determinação dos valores de grau médio de acetilação $(\overline{G A})$ de quitosana e grau médio de substituição $(\overline{G S})$ dos derivados $O$-acilados de quitosana.

$\mathrm{Na}$ aquisição dos espectros aproximadamente $6 \mathrm{mg}$ da amostra foram solubilizados em $1 \mathrm{~mL}$ de solução de $\mathrm{HCl} / \mathrm{D}_{2} \mathrm{O} 1 \%$ (v/v), sob agitação magnética constante, durante 24 horas, a $25^{\circ} \mathrm{C}$. A solução resultante foi transferida para tubo de quartzo (Aldrich 527-PP, $\phi=5 \mathrm{~mm}$ ) e as condições empregadas na aquisição do espectro foram: a) supressão de água com sequência de pulsos 1-1, com intervalo de 3s entre os pulsos de supressão; b) acúmulo de 32 varreduras; c) intervalo de $7 \mathrm{~s}$ de relaxação; d) temperatura de $80^{\circ} \mathrm{C}$; e) janela espectral de $10.0 \mathrm{ppm}$.

O grau médio de acetilação de quitosana $(\overline{G A})$ foi determinado pela razão entre as áreas dos sinais atribuídos aos hidrogênios da metila dos grupos acetamido das unidades GlcNAc e aos hidrogênios ligados aos carbonos 2 - 6 do anel glicopiranosídico, conforme a Equação 1 (HIRAI; ODANI; NAKAJIMA, 1991; DELEZUK et al., 2011; SILVA et al., 2015).

$$
\% \overline{G A}=\left(\frac{A_{\mathrm{CH}_{3}} / 3}{A_{\mathrm{H}_{2}-H_{6}} / 6}\right) * 100
$$

onde:

$\mathrm{A}_{\mathrm{CH} 3}=$ área dos hidrogênios metílicos do grupo acetamido; 
$\mathrm{A}_{\mathrm{H} 2-\mathrm{H} 6}=$ área do hidrogênio ligado ao carbono $\mathrm{C}(2-6)$ do anel glicopiranosídico.

Os graus médios de substituição $(\overline{G S})$ dos derivados 3,6-O, $O^{\prime}$ - dimiristoilquitosana foram calculados pela razão dos valores das integrais dos sinais em $\approx 0,8 \mathrm{ppm}$ (referente ao grupo $\mathrm{CH}_{3}$ do grupo miristoíla) e em $\approx 3,0-4,5 \mathrm{ppm}$ (referentes aos hidrogênios dos carbonos 2 - 6 do anel glicopiranosídico (Equação 2) e também pela razão dos valores das integrais do pico referente ao $\mathrm{CH}_{3}$ do substituinte miristoíla e do hidrogênio do carbono 2 do anel glicopiranosídico (Equação 3).

$$
\begin{gathered}
\% \overline{G S}=\left(\frac{A_{M e} / 3}{A_{H_{2}-H_{6}} / 6}\right) * 100 \\
\% \overline{G S}=\left(\frac{A_{M e} / 3}{A_{H_{2}}}\right) * 100
\end{gathered}
$$

onde:

$\mathrm{A}_{\mathrm{Me}}=$ área dos hidrogênios metílicos do grupo miristoíla;

$\mathrm{A}_{\mathrm{H} 2-\mathrm{H} 6}=$ área do hidrogênio ligado ao carbono C(2-6) do anel glicopiranosídico;

$\mathrm{A}_{\mathrm{H} 2}=$ hidrogênio do carbono 2 do anel glicopiranosídico.

\subsubsection{Ressonância magnética nuclear de carbono $\left(\operatorname{RMN}{ }^{13} \mathrm{C}\right)$}

A análise de $\mathrm{RMN}$ de ${ }^{13} \mathrm{C}$ no estado sólido foi realizada utilizando um espectrofotômetro Bruker Avance 400, acoplado a magical angle spinning (MAS) double-resonance de $100.5 \mathrm{MHz}$ $\left({ }^{13} \mathrm{C}\right)$ and $400.0 \mathrm{MHz}\left({ }^{1} \mathrm{H}\right)$. Foi utilizado um sistema pneumático para controlar a frequência de fiação a $12 \mathrm{kHz}( \pm 1 \mathrm{~Hz})$. Utilizaram-se intensidades de campo correspondentes a comprimentos de $\pi$ / 2 comprimentos de $4 \mu \mathrm{s}\left({ }^{13} \mathrm{C}\right)$ e $3,5 \mu \mathrm{s}\left({ }^{1} \mathrm{H}\right)$ para a transferência de polarização de bloqueio de spin e $70 \mathrm{kHz}$ para desacoplamento dos prótons. Os espectros quantitativos de ${ }^{13} \mathrm{C}$ da 
quitosana e do derivado QCM foram obtidos através do método de excitação MultiCP (multipolarização) recentemente proposto (JOHNSON; SCHMIDT-ROHR, 2014).

O grau médio de acetilação da quitosana foi obtido a partir da intensidade relativa do sinal dos carbonos da metila ( $\left.\mathrm{I}_{\mathrm{CH} 3}\right)$ e glucopiranose (IC1, IC2, IC3, IC4, IC5, IC6), de acordo com a literatura (OTTØY; VÅRUM; SMIDSRØD, 1996; HEUX et al., 2000). O grau médio de substituição de QCM foi obtido a partir das intensidades relativas dos carbonos $\mathrm{C}=\mathrm{O}$ (161169 ppm) e do carbono $\mathrm{C} 1$ do anel glucopiranose (100 a 116 ppm). Ambos os parâmetros, i. e. $\overline{D A}$ da quitosana e $\overline{D S}$ do derivado, foram calculados ajustando funções gaussianas para reduzir o erro resultante da relação sinal-ruído (HEUX et al., 2000).

\subsubsection{Difração de raios $X$}

A análise de difração de raios $\mathrm{X}$ foi executada para permitir a distinção de diferentes arranjos e graus de ordenamento, ou de cristalinidade. As medidas de difração de raios-X foram realizadas em difratômetro RIGAKU com tubo de cobre $(\lambda=1,54 \AA)$, no intervalo de 5-60', empregando varredura contínua, com velocidade de $1 \%$ min. A tensão e a corrente utilizadas foram de $50 \mathrm{kV}$ e $100 \mathrm{~mA}$, respectivamente.

Com intuito de estimar o índice de cristalinidade $(\mathrm{CrI})$ das amostras de quitosana e dos derivados 3,6-O,O'- miristoilquitosana foi utilizado o método de Focher (BELTRAME; NAGGI; TORRI, 1990) (Equação 4).

$$
\mathrm{CrI}=\frac{\mathrm{I}_{200}-\mathrm{I}_{\mathrm{am}}}{\mathrm{I}_{200}}
$$

onde,

$\mathrm{I}_{200}=$ pico de máxima intensidade $\left(2 \theta \approx 20^{\circ}\right)$ para o plano de reflexão $(200)_{\mathrm{h}}$;

$\mathrm{I}_{\mathrm{am}}=$ intensidade da região amorfa $\left(2 \theta \approx 16^{\circ}\right)$. 


\subsubsection{Teste de Solubilidade}

A determinação da solubilidade das amostras de quitosanas (QC e QD) e derivados 3,6$O, O^{\prime}$ - dimiristoilquitosana em solução aquosa foi baseada na turbidez de suas soluções. As amostras foram dissolvidas em $\mathrm{HCl} 0,1 \mathrm{M}(\mathrm{Cp}=1 \mathrm{~g} / \mathrm{L})$. Os $\mathrm{pH}$ das soluções foram ajustados com soluções aquosas de $\mathrm{HCl}$ e $\mathrm{NaOH}$. As transmitâncias das soluções foram registradas em um espectrômetro Shimatzu UV-3600, utilizando-se uma cela de quartzo de $1 \mathrm{~cm}$. As solubilidades das amostras em diferentes pHs foram estimadas por medidas de transmitância das soluções em $\bar{v}=600 \mathrm{~cm}^{-1}$. As amostras foram consideradas insolúveis quando suas soluções apresentaram valores de transmitância inferiores a 80\% (JINTAPATTANAKIT et al., 2008).

\subsubsection{Termogravimetria}

A termogravimetria (TGA) é uma técnica na qual a massa de uma substância é medida em função da temperatura, enquanto submetida a uma programação controlada de aquecimento.

As análises termogravimétricas das amostras de quitosana e dos derivados QDM foram executadas em equipamento TGA-50, da Shimadzu. As medidas foram efetuadas em atmosfera dinâmica de ar sintético com vazão de $20 \mathrm{~mL} \mathrm{~min}^{-1}$.. Assim, a amostra (8 mg) foi colocada em suporte de platina e submetida a aquecimento $\left(10^{\circ} \mathrm{C} \min ^{-1}\right)$ desde a temperatura ambiente até $95^{\circ} \mathrm{C}$ (permanecendo a $95^{\circ} \mathrm{C}$ durante 20 minutos para eliminação de água), e de $95^{\circ} \mathrm{C}$ até $800^{\circ} \mathrm{C}$ (permanecendo a $800^{\circ} \mathrm{C}$ por 5 minutos).

\subsubsection{Molhabilidade}

A molhabilidade da quitosana comercial e dos derivados QCM1 e QCM4 foi avaliada através de medidas de ângulo de contato, usando o método sessile drop (LV et al., 2014). As análises foram realizadas no aparelho de ângulo de contato OCA15, DATAPHYSICS 
Instruments Co. Ltd., Alemanha, à temperatura ambiente. As amostras na forma de pastilhas foram colocadas sobre o suporte e uma gota de água ultrapura $(4 \mu \mathrm{L})$ foi colocada sobre a superfície usando uma micro seringa. Uma câmara CCD de alto desempenho registrou o ângulo de contato inicial, logo que a gota foi depositada na superfície das amostras (LV et al., 2014), (CHEN et al., 2013).

\subsubsection{Concentração de agregação crítica (CAC)}

A CAC foi determinada pelo método de condutividade. As CMCs das amostras QCM1 e QCM4 dissolvidas em ácido acético $0,1 \mathrm{~mol} \mathrm{~L}^{-1}$, foram estimadas a partir da titulação condutimétrica no equipamento Consort C863, Espanha, realizada a $25^{\circ} \mathrm{C}$. O procedimento consistiu na medição da condutividade de várias concentrações de amostra $\left(1 \times 10^{-6}\right.$ a $1 \mathrm{mg} \mathrm{mL}$ $\left.{ }^{1}\right)$, sob agitação constante (SHAH, 2008).

\subsubsection{Eficiência de Encapsulação (EE)}

O fármaco (PTX) não encapsulado foi recolhido e a sua concentração foi analisada por HPLC-UV, conforme descrito no item abaixo "Instrumento e condições de análise de HPLC". Os experimentos foram realizados em triplicata, a $25^{\circ} \mathrm{C}$, e a área total do pico foi utilizada para quantificar o PTX livre. Os resultados foram obtidos a partir da Equação 5.

$$
\mathrm{EE} \%=\frac{\text { Fármaco total- Fármaco livre }}{\text { Fármaco total }} \times 100 \quad \text { Equação } 5
$$

A eficiência de encapsulação do fármaco CPT foi determinada através do método indireto de quantificação de CPT livre. O fármaco livre foi dissolvido em DMSO e a concentração do fármaco foi determinada pela absorbância em $370 \mathrm{~nm}\left(25^{\circ} \mathrm{C}\right)$, utilizando um espectrofotometro UV-Vis (Synergy 2, Biotek Instruments Ltda, USA). A quantidade de CPT 
carregada nas micelas foi determinada pela diferença entre a quantidade de fármaco adicionado na preparação e a quantidade de fármaco livre. A eficiência de encapsulação também foi calculada de acordo com a Equação 5.

\subsubsection{Validação do método segundo a ANVISA}

\subsubsection{Determinação do comprimento de onda de máxima absorção de CPT na região do ultravioleta}

Soluções de concentração $1 \mathrm{mg} \mathrm{mL} \mathrm{m}^{-1}$ de CPT em DMSO foram submetidas a uma varredura entre 200 e $400 \mathrm{~nm}$, em espectrofotômetro UV-Vis a fim de se verificar o comprimento de onda no qual o fármaco apresenta seu pico de máxima absorção.

\subsubsection{Especificidade / Seletividade}

Com a finalidade de avaliar a interferência do polímero (QCM1) na quantificação da camptotecina e confirmar que os resultados do ensaio não são afetados pelo polímero, a especificidade/seletividade foi determinada avaliando o espectro de absorção do polímero entre 200 e $400 \mathrm{~nm}$. Soluções contendo $5 \mathrm{mg} \mathrm{mL}^{-1}$ de QCM1 em ácido acético $1 \mathrm{~mol} \mathrm{~L}^{-1}$, foram submetidas a varreduras entre 200 e 400 nm, no espectrofotômetro UV-Vis.

\subsubsection{Linearidade e Intervalo}

A linearidade do método foi determinada através da obtenção da curva analítica de camptotecina. A partir de soluções estoque contendo $1 \mathrm{mg} \mathrm{mL} \mathrm{m}^{-1}$ de camptotecina, foram preparadas diluições com concentrações variando de 5 a $100 \mu \mathrm{g} \mathrm{mL}^{-1}$, em triplicata. $\mathrm{O}$ intervalo foi determinado a partir da faixa linear apresentada pelas curvas analíticas obtidas. 


\subsubsection{Precisão}

A precisão foi avaliada em três níveis de concentração, baixa $\left(15 \mu \mathrm{g} \mathrm{mL} \mathrm{L}^{-1}\right)$, média $(25 \mu \mathrm{g}$ $\left.\mathrm{mL}^{-1}\right)$ e alta $\left(50 \mu \mathrm{g} \mathrm{mL}^{-1}\right)$, em triplicata, a partir de solução estoque a $1 \mathrm{mg} \mathrm{mL}^{-1}$, considerando o intervalo linear do método, e expressa como o coeficiente de variação, calculado segundo a

\section{Equação 6:}

$$
\mathrm{CV}(\%)=\frac{D P}{C M D} \times 100
$$

Equação 6

onde, DP é o desvio padrão e CMD a concentração média determinada (BRASIL, 2003).

Foi determinada a precisão intra-corridas com análises realizadas em um único dia pelo mesmo analista e a precisão inter-corridas com análises realizadas em dias diferentes por analistas diferentes.

\subsubsection{Exatidão}

A exatidão foi determinada utilizando três diferentes concentrações, baixa $\left(15 \mu \mathrm{g} \mathrm{mL}^{-1}\right)$ média $\left(25 \mu \mathrm{g} \mathrm{mL}^{-1}\right)$ e alta $(50 \mu \mathrm{g} \mathrm{mL}-1)$, considerando a faixa de linearidade do método. As diluições foram preparadas a partir de solução estoque a $1 \mu \mathrm{g} \mathrm{mL} \mathrm{m}^{-1}$. Realizaram-se seis determinações por concentração e a exatidão foi calculada a partir da Equação 7:

$$
\text { Exatidão }(\%)=\frac{C}{C o} \times 100
$$

onde, $C$ é a concentração média determinada experimentalmente e $C O$ é a concentração teórica (BRASIL, 2003). 


\subsubsection{Limite de Detecção e Limite de Quantificação}

Os limites de detecção (LD) e de quantificação (LQ) foram determinados por meio da análise de soluções de concentrações decrescentes de CPT até o menor nível detectado (de 100 a $0,5 \mu \mathrm{g} \mathrm{mL}^{-1}$ ), em triplicata, e calculados através das Equações 8 e 9:

$$
\begin{array}{rr}
L D=\frac{3 x D P a}{I C} & \text { Equação 8 } \\
L D=\frac{10 x D P a}{I C} & \text { Equação 9 }
\end{array}
$$

onde, $L D$ é o limite de detecção, $L Q$ é o limite de quantificação, $D P a$ é o desvio padrão do intercepto com o eixo $y$ das três curvas construídas com as concentrações decrescentes do fármaco e IC é o coeficiente angular da curva analítica (BRASIL, 2003).

\subsubsection{Tamanho médio e morfologia das micelas}

O índice de polidispersividade, o tamanho médio e o potencial zeta das micelas foram medidos por espalhamento dinâmico de luz (DLS), em ângulo de detecção de $173^{\circ}$, empregando o equipamento Zetasizer Nano ZS, Malvern, Reino Unido. Foram feitas três réplicas de cada formulação produzida. As análises de morfologia das micelas foram realizadas por Microscopia Eletrônica de Transmissão (MET) utilizando o equipamento JEOL JEM 1400 TEM (Tóquio, Japão). As imagens obtidas foram gravadas digitalmente usando o Gatan SC 1100 câmera Orius CCD (Warrendale, PA, EUA). 


\subsubsection{Estudo in vitro}

\subsubsection{Ensaio de citotoxicidade}

A toxicidade das amostras de QCM, das micelas carregadas com fármaco e do fármaco livre foram avaliadas nos modelos celulares Caco-2 e HT29-MTX, utilizando o reagente MTT [brometo de 3-(4,5-dimetiliazol-2- il)-2,5-difeniltetrazólio]. As células foram cultivadas em frascos de cultura com meio de cultura celular (DMEM) suplementado com 10\% (v/v) de soro fetal bovino (FBS), 1\% (v/v) de L-glutamina, 1\% (v/v), aminoácidos não-essenciais (NEAA), e $1 \%$ (v/v), mistura antibiótico (concentração de $100 \mu \mathrm{g} \mathrm{mL}^{-1}$ de penicilina e $100 \mu \mathrm{g} \mathrm{mL}^{-1}$ de estreptomicina). As células foram semeadas $(200 \mu \mathrm{L})$ em poços de placas de 96 poços com

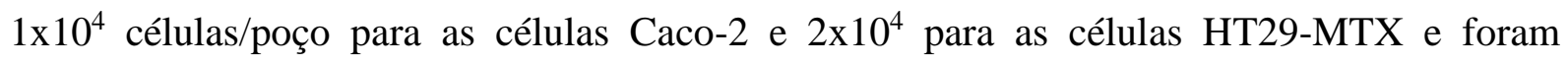
incubadas durante a noite sob condição padrão, para alcançar o crescimento exponencial antes do ensaio. No intervalo de 24 horas, o meio foi removido e as células foram lavadas duas vezes com $200 \mu \mathrm{l}$ de solução salina tamponada com fosfato (PBS). Depois, as células foram tratadas com as amostras nas concentrações de $0,001-1000 \mu \mathrm{g} \mathrm{mL}{ }^{1}$. O controle negativo foi DMEM e o controle positivo foi o Triton X-100 (1\% v/v). As células cultivadas foram incubadas durante 24 horas na presença de diferentes concentrações de amostras. Em seguida, as amostras foram removidas e lavadas com PBS e $200 \mu \mathrm{L}$ do reagente MTT (5 mg ml${ }^{1}$ ) foram adicionados, seguido por um período de incubação de 4 horas. Após, o MTT foi removido e $200 \mu \mathrm{L}$ de DMSO foram adicionados a cada poço para dissolver os cristais de formazan. As placas foram agitadas vigorosamente durante $10 \mathrm{~min}$ no interior do leitor de microplacas. A intensidade de absorbância foi medida em $570 \mathrm{~nm}$, relativo ao formazan, em relação à absorbância de referência em 630 nm. A viabilidade celular foi calculada a partir da Equação 10: 
Viabilidade $(\%)=\frac{\text { Valor Experimental }- \text { Controle Negativo }}{\text { Controle Positivo }- \text { Controle Negativo }} \times 100 \quad$ Equação 10

\subsubsection{Ensaio de permeabilidade}

Neste ensaio, o modelo de monocultura de células Caco-2 e o modelo de co-cultura Caco-2: HT29-MTX na proporção de 90:10 foram semeadas nas placas Transwell $^{\mathrm{TM}}$ Falcon (membrana de PET transparente com diâmetro de poro de $3 \mu \mathrm{m}, 4,67 \mathrm{~cm}^{2}$ ). As células intestinais foram semeadas no compartimento apical dos inserts Transwell $^{\mathrm{TM}}$ até uma densidade final de $4,5 \times 10^{5}$ células $/ \mathrm{cm}^{2}$ por insert. As células foram cultivadas até formarem uma monocamada durante 21 dias, com a substituição do meio de cultura todos os dias. Antes dos ensaios de permeabilidade, o meio de cultura foi removido de ambos os compartimentos e o insert foi lavado duas vezes com solução tamponada de Hank pré-aquecida (HBSS), depois substituído por um novo HBSS e deixado para equilibrar durante 30 min a $37^{\circ} \mathrm{C}$.

Os estudos de permeabilidade do fármaco livre e das micelas carregadas com fármaco foram realizados a $37^{\circ} \mathrm{C}$ durante $3 \mathrm{~h}$ e, em diferentes tempos $(15,30,45,60,90,120$ e 180 minutos) $200 \mu \mathrm{L}$ de cada amostra foram retirados do compartimento basolateral do insert Transwell $^{\mathrm{TM}}$ e foi adicionado o mesmo volume de HBSS pré-aquecido para substituir o volume retirado. No final do ensaio, todo o volume $(1,5 \mathrm{~mL})$ do compartimento apical foi removido para análise posterior. Todas as amostras foram quantificadas por análise por HPLC, conforme descrito no item Instrumento e condições de análise de HPLC.

A integridade das monocamadas das células foi avaliada antes da troca do meio (de duas a três vezes por semana) e durante os estudos de permeabilidade, utilizando um Instrumento Voltohímetro Epitelial EVOM com eletrodos (Instrumentos de Precisão Mundial, Sarasota, FL, EUA) (ARAÚJO; SARMENTO, 2013). Os resultados de permeabilidade foram expressos em 
massa acumulada $(\mu \mathrm{g})$ e os valores de TEER (resistência elétrica transepitelial) foram normalizados subtraindo o valor de resistência do insert vazio e expressos em percentagem.

\section{Instrumento e condiç̃es de análise de HPLC}

Para quantificação do fármaco PTX foi utilizado o equipamento de cromatografia de alto desempenho em fase líquida (HPLC) Merck-Hitachi 7000 com a coluna LiChrospher® 100 RP-18 $5 \mu \mathrm{m}$ - Merck Millipore foi utilizada para a separação e identificação. A fase móvel foi constituída por metanol/água $(65: 35 \mathrm{v} / \mathrm{v})$, a temperatura e taxa de fluxo foram fixados em $25^{\circ} \mathrm{C}$ e $1 \mathrm{~mL} \mathrm{~min}{ }^{-1}$, respectivamente. A absorbância foi determinada em $227 \mathrm{~nm}$, comprimento máximo de onda que caracteriza o PTX.

$\mathrm{Na}$ quantificação da CPT foi utilizado equipamento Shimadzu UFLC Prominence System (USA) equipado com duas bombas LC-20AD, amostrador automático SIL-20AC, coluna CTO-20AC, degaseificador DGU-20A5, sistema de controle CBM-20A e LC Solution, Version 1.24 SP1 (Shimadzu). O Shimadzu RF-10Axl detector de fluorescência (FD) acoplado ao LC System foi usado para detecção da área do pico da CPT. A análise foi realizada a $30^{\circ} \mathrm{C}$, em coluna de fase reversa (RP) MediterraneaTM Sea18 com $150 \mathrm{~mm} \times 4.0 \mathrm{~mm}, 5 \mu \mathrm{m}$, Teknokroma, Spain), acoplado à pré-coluna UltraguardTM (Guard column Sea18, $10 \mathrm{~mm} \times 3.2$ mm, Teknokroma, Spain). O método otimizado usado foi uma fase móvel de gradiente binário com tampão trietilamina $1 \%(\mathrm{v} / \mathrm{v})$ de $\mathrm{pH} 5.5$ como fase móvel A e a acetronitrila como fase móvel B com taxa de fluxo $1.2 \mathrm{~mL} / \mathrm{min}$ com $10 \mu \mathrm{L}$ de volume de injeção. O programa foi iniciado com gradiente de $75 \%$ de fase A e $25 \%$ de fase B e após 1 min o gradiente mudou continuamente até obter o gradiente de $40 \%$ A e $60 \%$ B que foi mantido por 9 min, então o gradiente foi novamente mudado para $75 \%$ de A e $25 \%$ B e permaneceu constante por 16 min. 
Os picos foram monitorados em excitação e emissão de comprimentos de onda de 360 e $440 \mathrm{~nm}$, respectivamente.

\subsubsection{Ensaio de Liberação}

Para estudar o perfil de liberação do fármaco in vitro a partir das micelas de QCM1, foram testadas duas condições diferentes, simulando os diferentes valores de $\mathrm{pH}$ encontrados ao longo do trato gastrointestinal após administração oral. Assim, o teste foi realizado utilizando fluido gástrico simulado sem enzima (FGSE, $\mathrm{HCl}$ 0,1 N, pH 1,2) e o fluido intestinal simulado sem enzima (FISE, PBS, pH 6,8). Os meios foram preparados com Tween $80^{\circledR}(1 \% \mathrm{v} / \mathrm{v})$ para assegurar sink conditions. Solução de $5 \mathrm{~mL}$ de micelas contendo fármaco foi introduzida em sacos de diálise (10 KDa, Thermo Scientific) que foi imerso em $40 \mathrm{~mL}$ de cada meio de liberação e em intervalos de tempo predeterminados $(0,25,0,5,1,2,4,8,12,24$ e $48 \mathrm{~h})$, foi removido $1 \mathrm{~mL}$ do meio de liberação e o mesmo volume foi reposto. Os ensaios foram realizados num agitador orbital a $37^{\circ} \mathrm{C}$ e $100 \mathrm{rpm}$ e determinou-se a quantidade de fármaco liberado por análise por HPLC. Cada experimento foi realizado em triplicata e os resultados foram apresentados como média e correspondente desvio padrão (média \pm DP).

\subsubsection{Análise Estatística}

Os experimentos foram realizados em triplicatas e os resultados são representados como média \pm desvio padrão (DP). Foi utilizada a ferramenta ANOVA bidirecional com comparações múltiplas / pós-hoc de Bonferroni para analisar os dados de citotoxicidade e de permeabilidade aparente. O programa utilizado foi o GraphPadPrism software Inc., EUA, e o nível de significância foi estabelecido com probabilidades de $* \mathrm{p}<0,05, * * \mathrm{p}<0,01 \mathrm{e} * * * \mathrm{p}<0,001$. 


\section{RESULTADOS E DISCUSSÃO}

Com objetivo de facilitar a leitura e a compreensão dos resultados e discussões apresentados nesse trabalho, os mesmos foram divididos em três partes, conforme descritos abaixo:

PARTE 1 - Caracterizações de quitosana e derivados $O$-acilado

Nesta seção são apresentados os resultados e discussões referentes à produção e caracterizações estruturais da quitosana DAIUS (QD), quitosana comercial (QC) e derivados $O$-acilado de quitosana. Os referidos polímeros foram caracterizados por espectroscopia no infravermelho (FTIR), espectroscopia de ressonância magnética nuclear de hidrogênio (RMN $\left.{ }^{1} \mathrm{H}\right)$ e carbono $\left(\mathrm{RMN}{ }^{13} \mathrm{C}\right)$, difração de raios- $\mathrm{X}$, termogravimetria, espectroscopia no ultravioleta visível (UV-vis), ângulo de contato e concentração micelar crítica.

PARTE 2 - Estudos de encapsulação e liberação do paclitaxel

Nesta seção são discutidos os resultados referentes aos estudos realizados com o fármaco modelo paclitaxel (PTX), sendo que as caracterizações foram realizadas com intuito de avaliar a capacidade dos derivados $O$-acilado solubilizar o PTX, investigar a eficiência de encapsulação e as propriedades in vitro usando células modelo de Caco-2 e HT29-MTX.

PARTE 3 - Estudos de encapsulação e liberação da camptotecina

Nesta seção são realizadas discussões referentes aos estudos realizados com o fármaco modelo camptotecina $(\mathrm{CPT})$ e as caracterizações realizadas foram as mesmas feitas para o paclitaxel conforme mencionado acima. 
A primeira parte do trabalho foi desenvolvido no laboratório de Físico-Química Orgânica do Instituto de Química de São Carlos - Universidade de São Paulo sob a orientação do Prof. Sérgio Paulo Campana Filho.

A segunda e a terceira parte foram realizadas nos laboratórios do Instituto de Investigação e Inovação em Saúde - Universidade do Porto- Portugal sob a orientação do Prof. Bruno Sarmento, durante o Doutorado - Sanduíche realizado no período de setembro de 2015 a agosto de 2016 . 


\subsection{Parte 1: Caracterização das quitosana e seu derivado $O$-acilado}

\subsubsection{Espectroscopia de Ressonância magnética nuclear de hidrogênio $\left(\mathbf{R M N}{ }^{1} \mathbf{H}\right)$}

As amostras de quitosana empregadas neste estudo, a saber QC e QD, apresentaram espectros de RMN ${ }^{1} \mathrm{H}$ muito semelhantes, sendo assim o espectro na Figura 9 é representativo para ambas as amostras de quitosana. Neste espectro foi observado os seguintes sinais característicos de quitosana: $a$ ) $\approx 2,2$ ppm, hidrogênios metílicos do grupo acetamida de unidades GlcNAc; $b$ ) $\approx 3,0-4,0$ ppm, hidrogênios ligados aos carbonos 2 - 6 de unidades GlcN e GlcNAc; $c$ ) $\approx 4,6 \mathrm{ppm}$ hidrogênio ligado ao carbono 1 de unidade GlcNAc e $d$ ) $\approx 4,9$ ppm, hidrogênio ligado ao carbono 1 de unidades GlcN. Segundo os cálculos de grau de acetilação $(\overline{G A})$, as amostras QC e QD apresentaram $\overline{G A}=5 \%$ e $\overline{G A}=15 \%$, respectivamente.

Figura 9: Espectro de $\mathrm{RMN}{ }^{1} \mathrm{H}(400 \mathrm{MHz})$ adquirido a $80^{\circ} \mathrm{C}$ a partir da solução da amostra QC em $\mathrm{DCl} / \mathrm{D}_{2} \mathrm{O} 1 \%(\mathrm{v} / \mathrm{v})$.

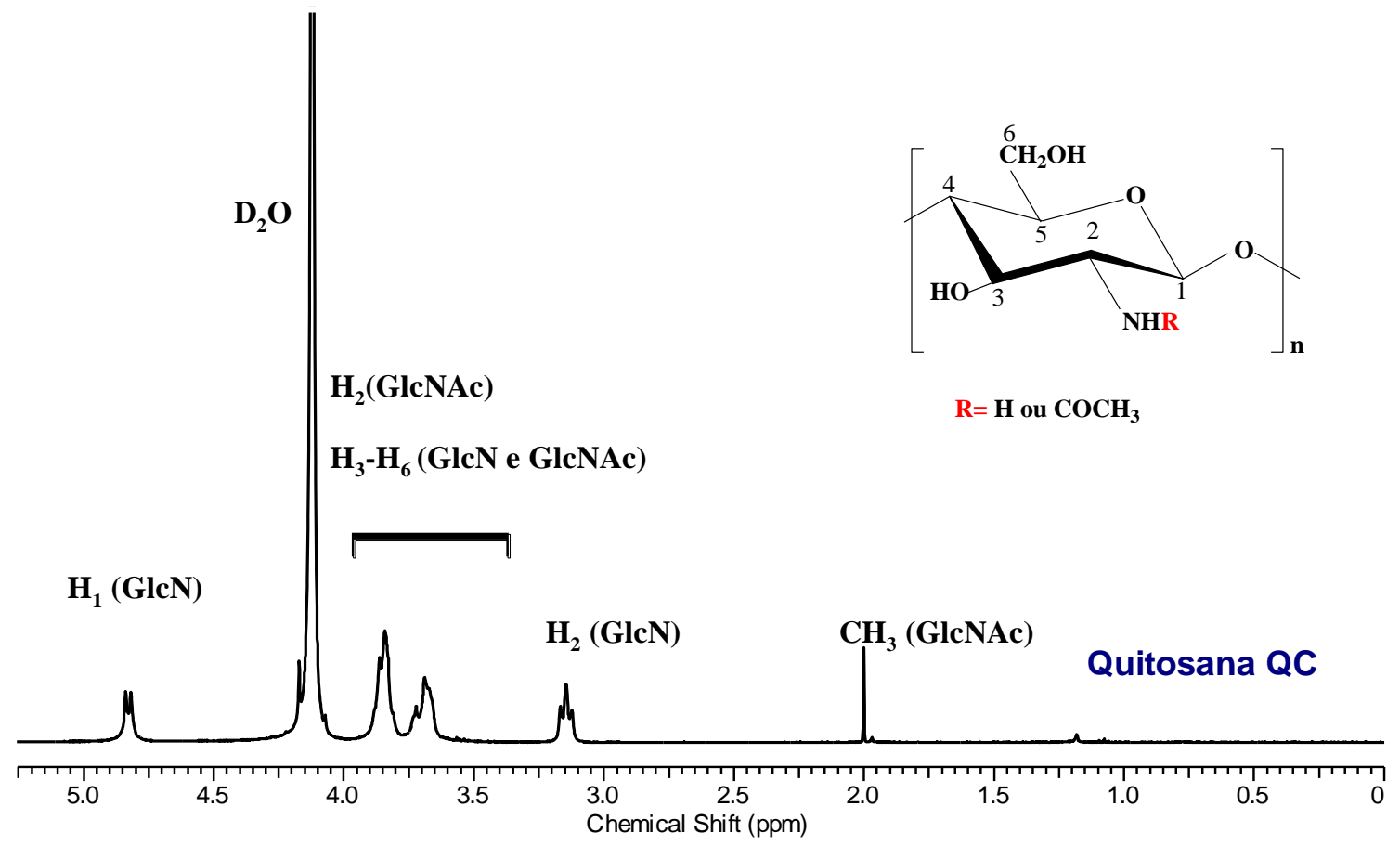


Os espectros das amostras do derivado 3,6-O, $O^{\prime}$ - dimiristoilquitosana se assemelham e, sendo assim, é apresentado apenas o espectro da amostra QCM2 (Figura 10), representativo do conjunto de amostras produzidas neste trabalho. Nesse espectro são identificados os seguintes sinais característicos do derivado QCM2: a) 0,9 ppm, hidrogênios referentes ao grupo metila $\left(\mathrm{CH}_{3}\right)$ do grupo miristoíla; $b$ ) 1,3 ppm, hidrogênios dos grupos metileno $\left(-\mathrm{CH}_{2}-\right)$ do grupo miristó́la; c) 1,7ppm, hidrogênios referentes ao metileno do carbono $\beta$ do grupo miristoíla; $d$ ) 2,3 ppm, hidrogênios referentes ao metileno do carbono $\alpha$ do grupo miristoíla; $e$ ) 3,2 ppm, hidrogênio ligado ao carbono 2 da unidade GlcN. Os sinais em 3,0 - 4,5 ppm são referentes aos hidrogênios dos carbonos 2 - 6 (HIRANO; YAMAGUCHI; KAMIYA, 2002; BADAWY et al., 2004, 2005; CHOI et al., 2007; HU et al., 2007). A partir da análise de RMN ${ }^{1} \mathrm{H}$, não foram observados sinais de $N$-substituição.

Figura 10: Espectro de $\mathrm{RMN}{ }^{1} \mathrm{H}(400 \mathrm{MHz})$ da amostra QCM2, solubilizada em $\mathrm{DCl} / \mathrm{D}_{2} \mathrm{O} 1 \%(\mathrm{v} / \mathrm{v}), 80^{\circ} \mathrm{C}$.

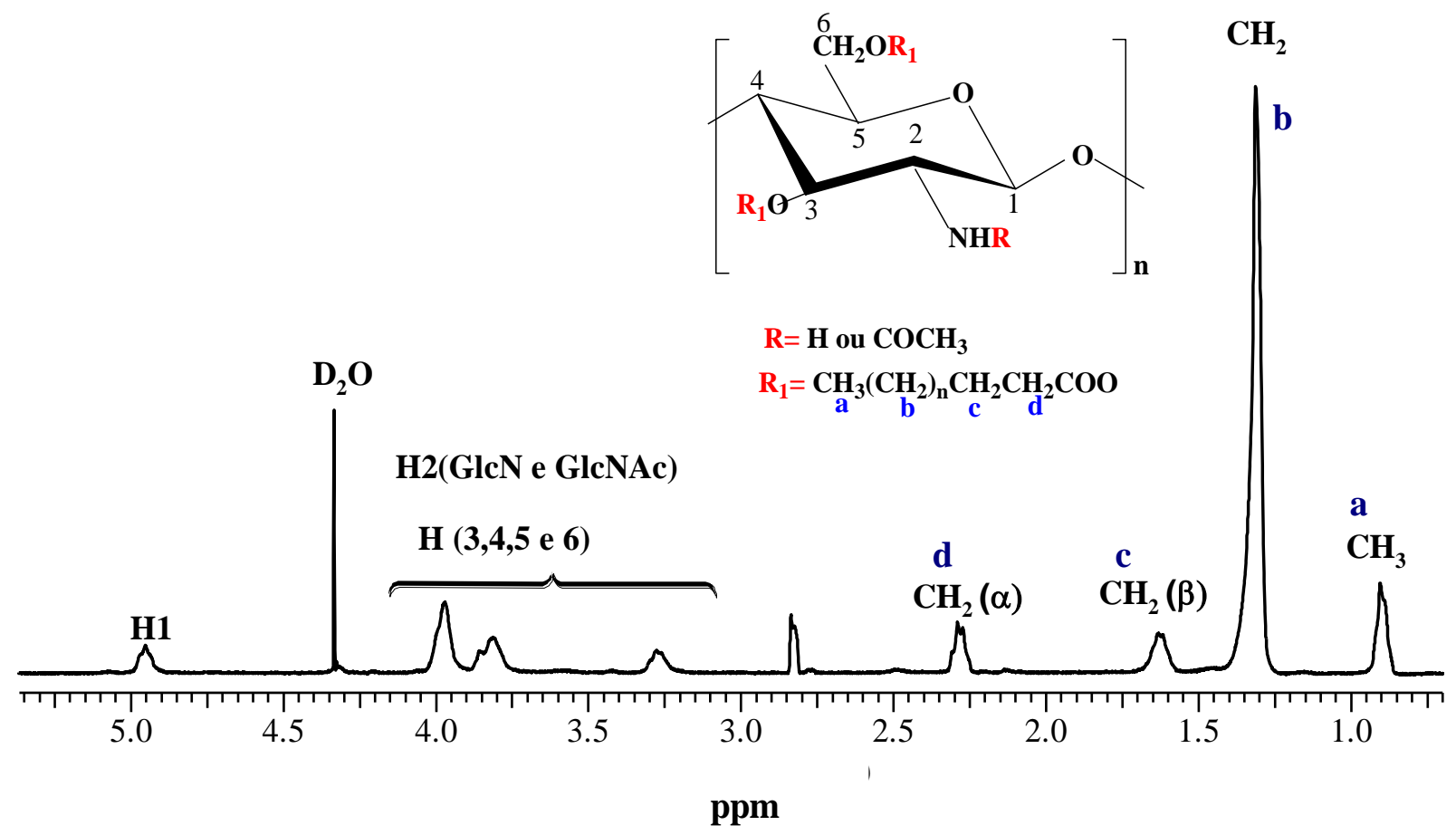


Os graus médios de substituição $(\overline{G S})$ das amostras dos derivados 3,6-O,O'dimiristoilquitosana (Tabela 2) foram calculados pela razão dos valores das integrais dos picos em $\approx 0,9 \mathrm{ppm}$, referente aos hidrogênios metílicos do substituinte $\left(\mathrm{CH}_{3}\right)$ e em $\approx 3,0-4,5 \mathrm{ppm}$ (referentes aos hidrogênios dos carbonos 2, 3, 4, 5 e 6 do anel glicopiranosídico) e também pela razão do valores das integrais do pico referente ao $\mathrm{CH}_{3}$ do substituinte $(\approx 0,9 \mathrm{ppm})$ e do hidrogênio do carbono $(\mathrm{C} 2)$ do anel glicopiranosídico $(\approx 3,2 \mathrm{ppm})$.

Tabela 2: Valores de grau de substituição $(\overline{\boldsymbol{G S}})$ dos derivados 3,6-O,O'- dimiristoilquitosana (QCMx e QDMx).

\begin{tabular}{ccc}
\hline Amostra & Razão Molar Q/CM & $\overline{\mathbf{G S}}(\%)^{*}$ \\
\hline QCM1 & $1: 0,075$ & 6,6 \\
QCM2 & $1: 0,1$ & 9,1 \\
QCM3 & $1: 0,2$ & 9,1 \\
QCM4 & $1: 0,5$ & 11 \\
\hline QDM1 & $1: 0,075$ & 7,3 \\
QDM2 & $1: 0.1$ & 7,8 \\
QDM3 & $1: 0,2$ & 7,8 \\
QDM4 & $1: 0,5$ & 13 \\
\hline
\end{tabular}

*Valores médios resultantes do emprego das equações 4 e 5.

Os resultados apresentados na Tabela 2 mostraram que à medida que a razão molar aumenta, há um aumento no grau de substituição, efeito observado nos derivados originados da quitosana QC e QD, no entanto, para a razão molar 0,2 não houve variação nos valores de $\overline{G S}$.

\subsubsection{Espectroscopia de Ressonância magnética nuclear de carbono $\left(\mathbf{R M N}{ }^{13} \mathbf{C}\right)$}

Os espectros de RMN de ${ }^{13} \mathrm{C}$ no estado sólido da quitosana e do derivado QCM1 são mostrados na Figura 11. Apesar do ajuste da função de Gaussian, o sinal de $\mathrm{C}=\mathrm{O}$ fraco e amplo em 180,6 ppm devido ao grupo acetamida leva a uma análise quantitativa não confiável de $\overline{D A}$. No entanto, o ajuste Gaussiano do sinal $\mathrm{CH}_{3}$, observado em 26 ppm, reduz fortemente o erro sistemático. Assim, o grau médio de acetilação de quitosana foi determinado como $\overline{D A} \approx$ 
6,5\%, em estreita concordância com o resultado obtido por $\mathrm{RMN}{ }^{1} \mathrm{H}$. Os desvios químicos dos sinais devidos aos carbonos do anel de glucopiranose da quitosana (Figura 11a) estão de acordo com a literatura, incluindo o dupleto característico de $\mathrm{C} 4$, observado a $\approx 82-88 \mathrm{ppm}$ (Heux et al., 2000). Os principais sinais devidos aos átomos de carbono da quitosana são observados com o mesmo desvio químico no espectro de RMN de ${ }^{13} \mathrm{C}$ de QCM1 e adicionalmente são observados os sinais de $\mathrm{C}=\mathrm{O}, \mathrm{CH}_{2}$ e $\mathrm{CH}_{3}$ pertencentes a porções de miristó́la, que são observados a 165 ppm, 20 - 35 ppm e a 15 ppm, respectivamente. Assim, devido à presença de numerosos grupos $-\mathrm{CH}_{2}$ - nas porções miristó́la de QCM1, observa-se um sinal intenso e acentuado a aproximadamente 30 ppm. Devido à sobreposição de sinais na região 15 - 45 ppm, a intensidade dos sinais dos grupos $\mathrm{CH}_{3} \mathrm{e}$ os grupos $-\mathrm{CH}_{2}$ - não podem ser utilizados para a determinação de $\overline{D S}$. Por conseguinte, foi determinado a partir da intensidade do sinal devido ao grupo carbonilo de QCM1 ( $\approx 165 \mathrm{ppm})$ tomando como referência o sinal devido a $\mathrm{C} 1(\approx$ $105,7 \mathrm{ppm}$ ), resultando em $\overline{D S} \approx 6,0 \%$, em acordo com os dados de $\mathrm{RMN}{ }^{1} \mathrm{H}$.

Figura 11: Espectro de RMN ${ }^{13} \mathrm{C}$ no estado sólido das amostras de quitosana (a) e QCM1 (b).

(a)

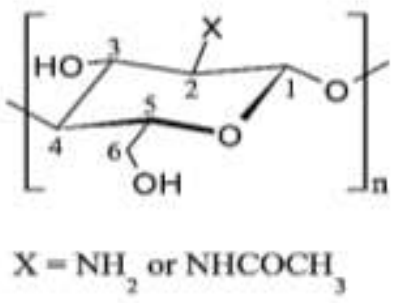

$$
\mathrm{C}=\mathrm{O}
$$
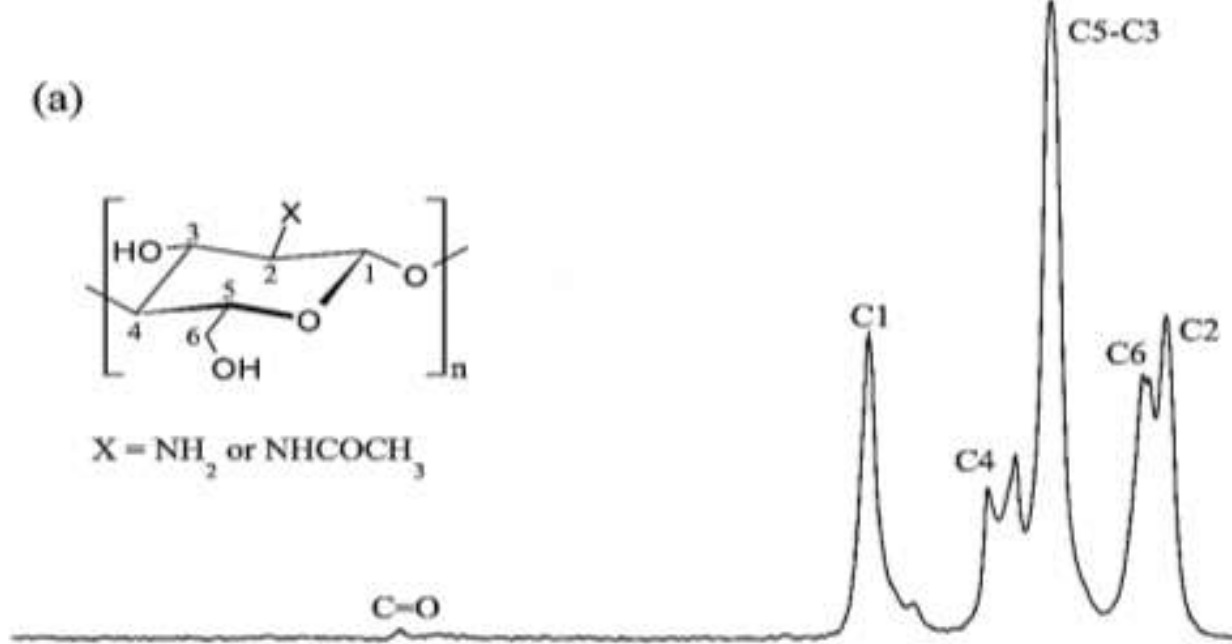
(b)

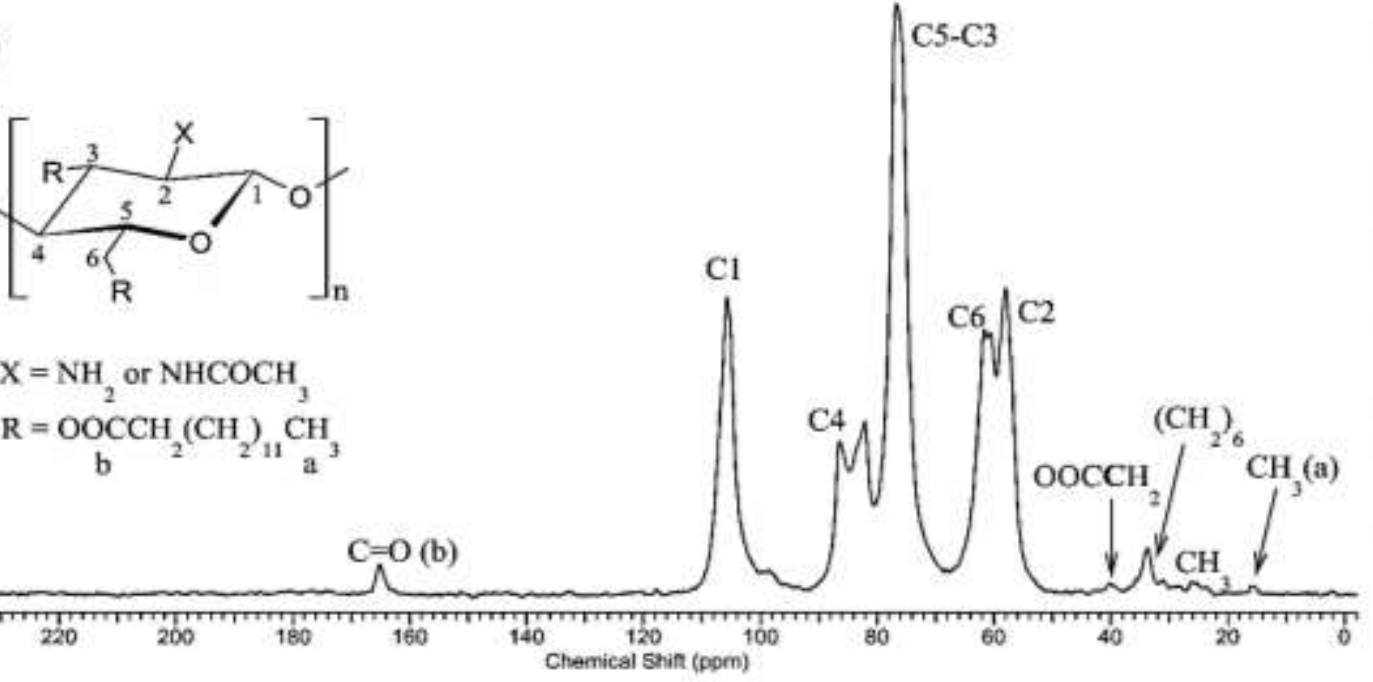

\subsubsection{Espectroscopia no infravermelho}

A partir das análises de espectroscopia no infravermelho, as amostras das quitosanas de partida, QC e QD, e as amostras do derivado 3,6-O, $O^{\prime}$ - dimiristoilquitosana foram identificadas por seus modos de vibração característicos, conforme apresentado na Tabela 4.

As amostras QC e QD apresentaram espectros semelhantes e, sendo assim, é apresentado apenas o espectro da amostra QC (Figura 12), que apresenta as seguintes bandas principais: 3500 - $3300 \mathrm{~cm}^{-1}$ deformações axiais de O-H e $N-\mathrm{H}, 2890-2720 \mathrm{~cm}^{-1}$ deformação axial de C-H, $1670-1650 \mathrm{~cm}^{-1}$ deformação axial C=O de amida I, $1600-1500 \mathrm{~cm}^{-1}$ deformação angular $N$-H de amida II, 1380 - $1370 \mathrm{~cm}^{-1}$ deformação angular de C-H, 1320 - $1300 \mathrm{~cm}^{-1}$ banda de deformação axial de C-N de amida III, , 1070-1060 cm-1 deformação axial simétrica de CO-C (DESBRIE et al., 2001; RINAUDO, 2006; ABDOU; NAGY; ELSABEE, 2008; DELEZUK et al., 2011).

Tabela 3: Principais bandas de absorção e números de onda $\left(\mathrm{cm}^{-1}\right)$ das amostras de quitosana QC e QD

\begin{tabular}{cccc}
\hline Banda & $\bar{V}\left(\mathbf{c m}^{-\mathbf{1}}\right)$ & Banda & $\bar{V}\left(\mathbf{c m}^{-\mathbf{1}}\right)$ \\
\hline C=O Amida I & $\approx 1670-1650$ & Amida II & $\approx 1550$ e 1560 \\
Amida III & $\approx 1320-1300$ & OH & $\approx 3500-3000$ \\
- C-O & $\approx 1079-1060$ & C-H & $\approx 1380-1370$ \\
\hline
\end{tabular}


Tabela 4: Principais bandas de absorção e números de onda $\left(\mathrm{cm}^{-1}\right)$ dos derivados 3,6-O,O'dimiristoilquitosana

\begin{tabular}{cccc}
\hline Banda & $\bar{V}\left(\mathbf{c m}^{-\mathbf{1}}\right)$ & Banda & $\overline{V\left(\mathbf{c m}^{-\mathbf{1}}\right)}$ \\
\hline $\mathrm{C}-\mathrm{H}$ & $\approx 2980-2920$ & $\mathrm{C}-\mathrm{H}$ & $\approx 2860$ \\
R-CO-OR & $\approx 1740$ & & \\
\hline
\end{tabular}

A Figura 12 também apresenta o espectro da amostra do derivado QCM2, representativo dos demais derivados, no qual são observadas, além das bandas características de quitosana, as seguintes bandas que confirmam o sucesso da reação de acilação: i) 2980 $2920 \mathrm{~cm}-1$ e $2860 \mathrm{~cm}^{-1}$ atribuídas à deformação axial de grupos C-H dos grupos acila e ii) 1740 $\mathrm{cm}^{-1}$ banda referente à deformação axial da carbonila de éster (TONG et al., 2005; BALAN; BUTNARU; VERESTIUC, 2013; CAI et al., 2015; CHIU et al., 2009; CHOI et al., 2007; JIANG et al., 2006a).

Figura 12: Espectros na região do infravermelho das amostras QC e QCM2.

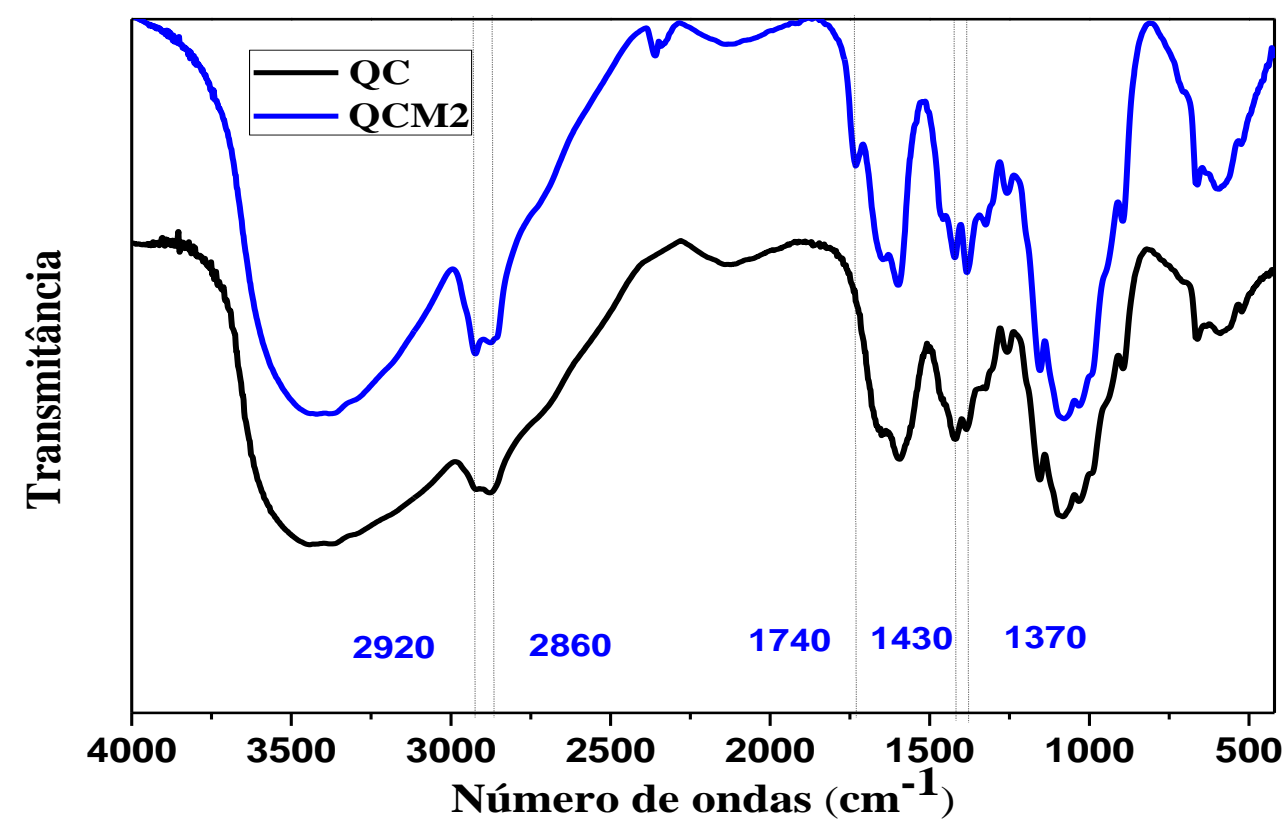

Os espectros mostrados na Figura 13, são referentes aos derivados 3,6- $O, O^{\prime}$ miristoilquitosana provenientes da quitosana QC, em todos os derivados foi possível observar a presença da banda em $1744 \mathrm{~cm}^{-1}$ referente à $O$-substituição, assim como os derivados 
produzidos a partir da quitosana QD (Figura 14). Entretanto, nos casos dos derivados QDM1 e QDM2, não foi nitidamente observada a banda referente à $O$-acilação em $\approx 1740 \mathrm{~cm}^{-1}$, o que pode ser atribuído à superposição com as bandas de deformação axial C=O de amida I (1670 $\left.1650 \mathrm{~cm}^{-1}\right)$ e de deformação angular $N$-H de amida II $\left(1600-1500 \mathrm{~cm}^{-1}\right)$, que são intensas devido à quitosana de partida ser mais acetilada $(\overline{G A}=15 \%)$. A $N$-substituição não foi evidenciada nos espectros de infravermelho dos derivados de quitosana, confirmando que a reação foi regiosseletiva, ocorrendo apenas $O$-substituição.

Figura 13: Espectros na região do infravermelho das amostras do derivado 3,6-O,O'- miristoilquitosana proveniente da quitosana $\mathrm{QC}$.

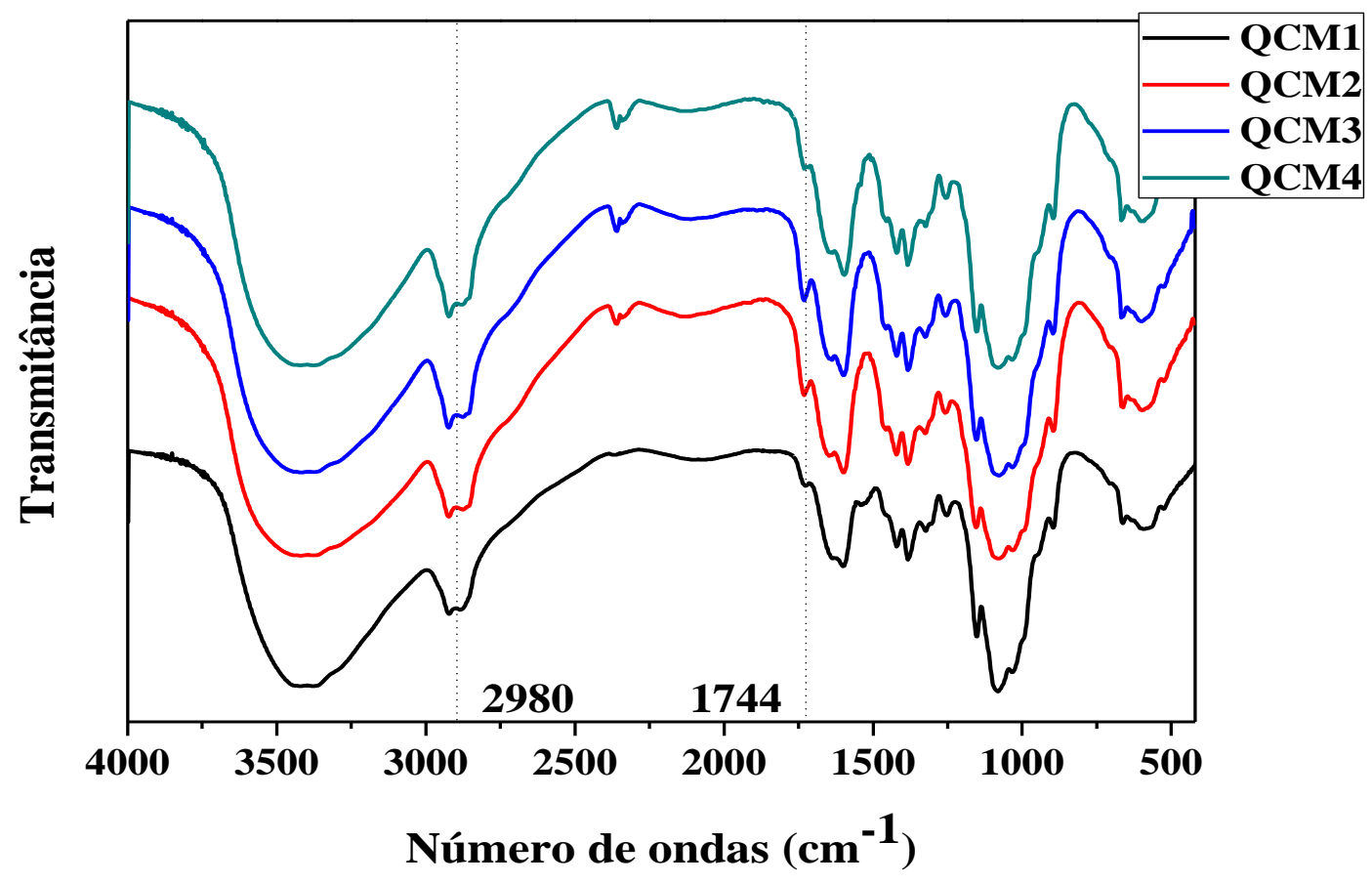


Figura 14: Espectros na região do infravermelho das amostras do derivado 3,6-O,O'- miristoilquitosana proveniente da quitosana QD.

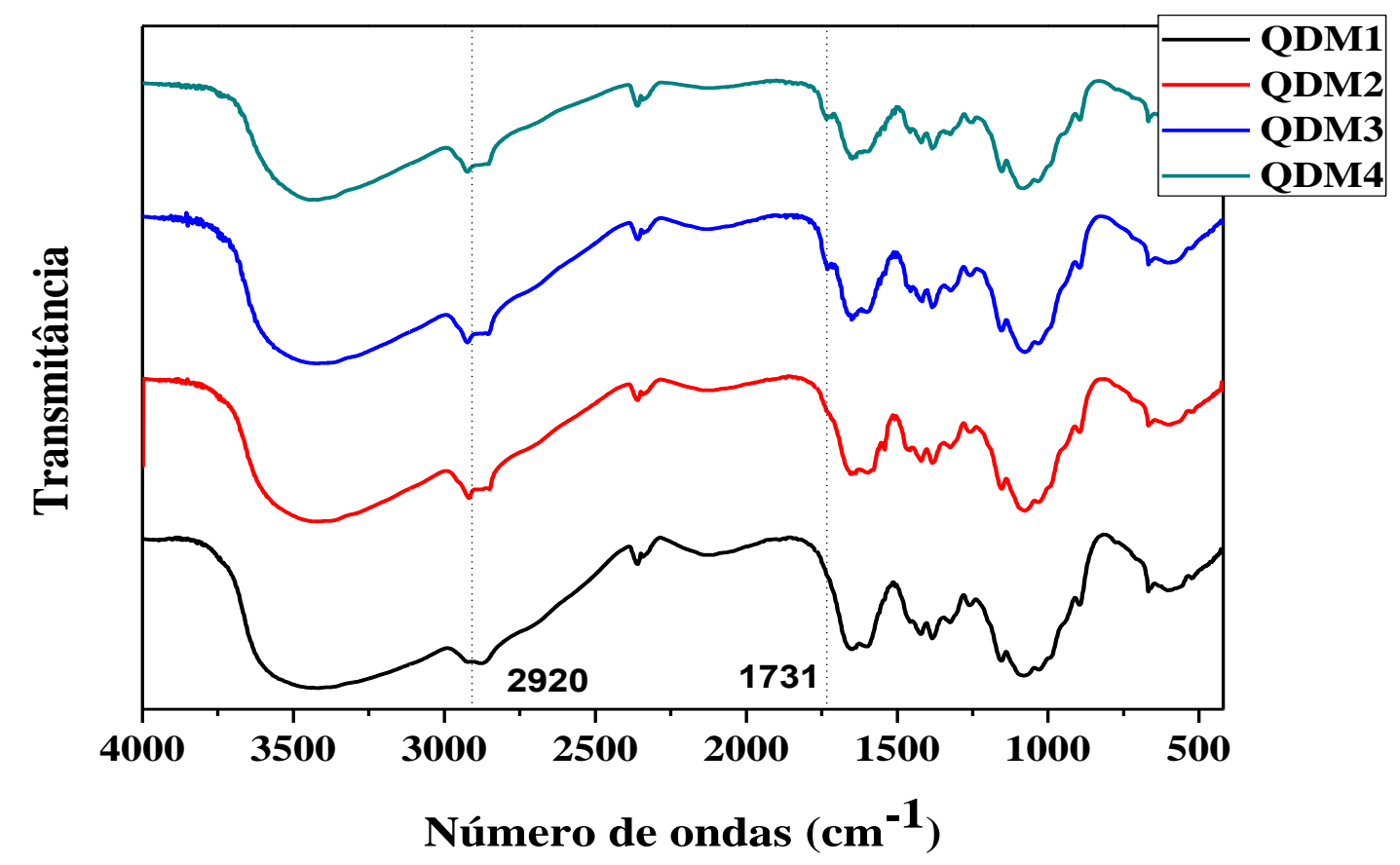

\subsubsection{Difração de raios-X}

A partir da técnica de difração de raios-X, foi possível observar a ocorrência dos diferentes arranjos e graus de ordenamento das quitosanas (QC e QD) e dos derivados 3,6O,O'- dimiristoilquitosana. Estudos realizados por Ogawa e colaboradores (OGAWA et al., 1984) afirmam que a quitosana apresenta diferentes formas, a saber hidratada, anidra e não cristalina, que são identificadas por seus diferentes padrões de difração. A polimorfa anidra, que pode ser obtida através do aquecimento da forma hidratada em água $\left(240^{\circ} \mathrm{C}\right)(\mathrm{OGAWA}$, 1991), ocorre a perda de moléculas de água e as interações hidrofóbicas são favorecidas. Após o tratamento de aquecimento e dissolução em solução de ácidos orgânicos é possível observar um sinal $2 \theta \approx 15^{\circ}$ característico da forma anidra (TABETA et al., 1987; OKUYAMA et al., 1999). Assim, como não são observados sinais em $2 \theta \approx 15^{\circ}$ nos difratogramas das amostras QC e QD (Figura 15), foi concluído que essas amostras não possuem contribuições da forma anidra. 
Figura 15: Difratogramas das amostras de quitosana a) QC e b) QD.

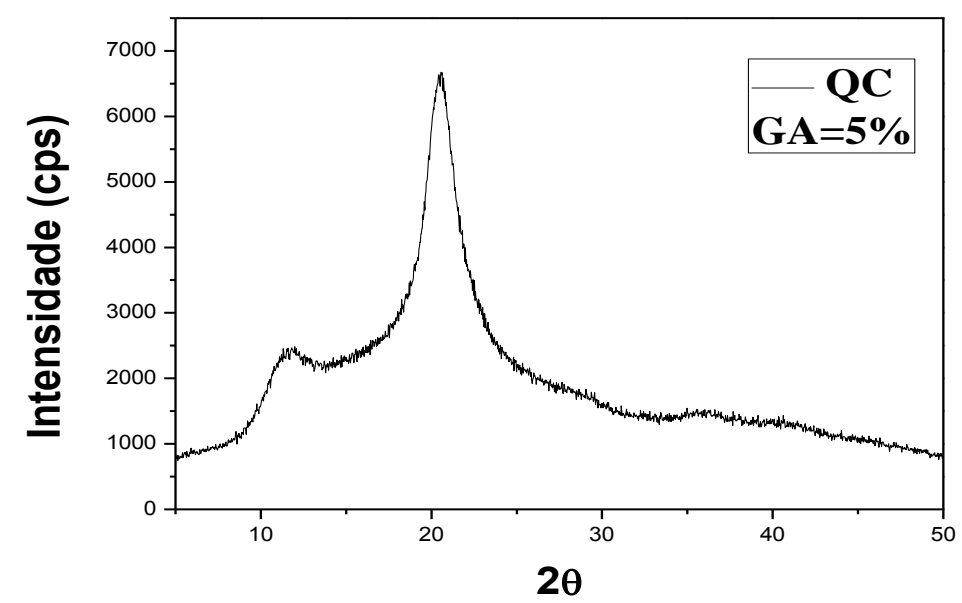

(a)

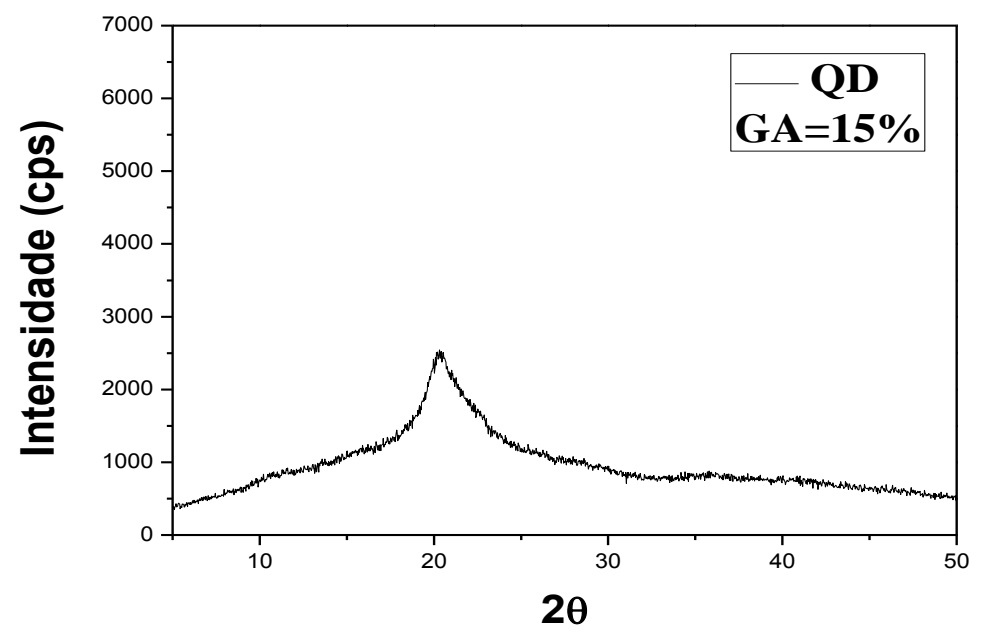

(b)

Por outro lado, a literatura registra que no difratograma da polimorfa hidratada de quitosana, os sinais característicos são observados em $2 \theta \approx 10^{\circ}$ e $\approx 20^{\circ}$ (CLARK; SMITH, 1996). Assim, analisando os difratogramas das amostras QC e QD (Figura 15), é constatado que ambas correspondem à estrutura hidratada de quitosana e também pode ser observado que as quitosanas QC e QD apresentam padrões de difração diferentes.

De fato, no difratograma da quitosana QC são observados dois picos cristalinos, intensos e bem definidos, em $2 \theta \approx 11^{\circ}$ e $2 \theta \approx 20$, entretanto o primeiro sinal não é observado 
no difratograma da quitosana QD, que também apresenta o segundo sinal menos e intenso e mais alargado quando comparado à quitosana QC. Tais diferenças podem ser justificadas nos seguintes termos: a) amostra QC passou pelo processo de purificação; b) as quitosanas QC e QD foram obtidas através de processos de desacetilação diferentes, QC por tratamento termoquímico e QD por irradiação de ultrassom de alta intensidade, c) as quitosanas QC e QD apresentam diferentes graus médios de acetilação $\overline{G A}=5 \%$ e $\overline{G A}=15 \%$, respectivamente. Relativo ao efeito da purificação, é conhecido que uma vez dissolvida em solução de ácido acético e reprecipitada, a quitosana adota um novo arranjo tridimensional de menor energia, e a "memória" da estrutura original é perdida (BATTISTI; CAMPANA-FILHO, 2008).

As diferenças nos arranjos das cadeias das amostras QC e QD no estado sólido também são atribuídas à ação da irradiação de ultrassom de alta intensidade durante a execução do processo DAIUS para conversão de beta-quitina na quitosana QD. De fato, quando o processo DAIUS é aplicado à suspensão de beta-quitina, ocorre o fenômeno conhecido como cavitação, que resulta na formação de bolhas cavitacionais, cujo colapso libera grande quantidade de energia e na formação de jatos de solventes a velocidades muito elevadas que fragmentam e limpam a superfície do material suspenso (CARDOSO; SIGNINI; CAMPANA-FILHO, 2001; DELEZUK et al., 2011).

Ao realizar a desacetilação, através do processo DAIUS, o fenômeno de cavitação contribui para a formação de um polímero que possui menor quantidade de domínios cristalinos (DELEZUK et al., 2011; PRICE, 1996; WANG; JIN; CHANG, 2009), enquanto que no processo convencional de desacetilação, através do qual a amostra QC foi obtida, o acesso aos sítios reativos é limitado, a desacetilação ocorre preferencialmente na superfície das partículas e, principalmente, nos domínios amorfos, mantendo assim a estrutura cristalina da quitina parcialmente íntegra.

Nos difratogramas das amostras QCMx (Figura 16) e QDMx (Figura 17), é observado um novo sinal em $2 \theta \approx 22^{\circ}$, que a intensidade do pico em $2 \theta=20^{\circ}$ diminui e que um sinal em $2 \theta \approx$ 
$11^{\circ}$, ausente no difratograma da amostra QD, é observado. O alargamento e a diminuição da intensidade do sinal em $2 \theta \approx 20^{\circ}$ são tomadas como evidências de diminuição da cristalinidade, como relatado na literatura (SUN et al., 2006).

Os difratogramas das amostras QCM2 e QCM3 (Figura 16), bem como aqueles das amostras QDM2 e QDM3 (Figura 17), apresentam muitas semelhanças, o que se justifica pelos respectivos valores de $\overline{G S}$, que são muito próximos. Nos difratogramas das amostras QCM4 e QDM4 são observados sinais mais definidos em $2 \theta \approx 11^{\circ} \mathrm{e} 2 \theta \approx 20^{\circ}$, além de um novo sinal em $2 \theta$ $\approx 22^{\circ}$, indicando que nesses casos o grau de ordenamento das cadeias poliméricas aumentou.

Figura 16: Difratogramas das amostras a) QCM1; b) QCM2; c) QCM3 e d) QCM4.

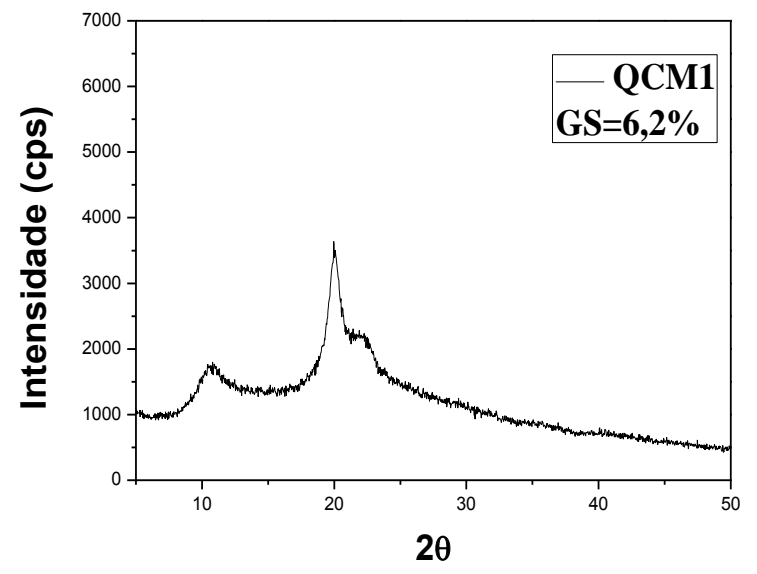

(a)

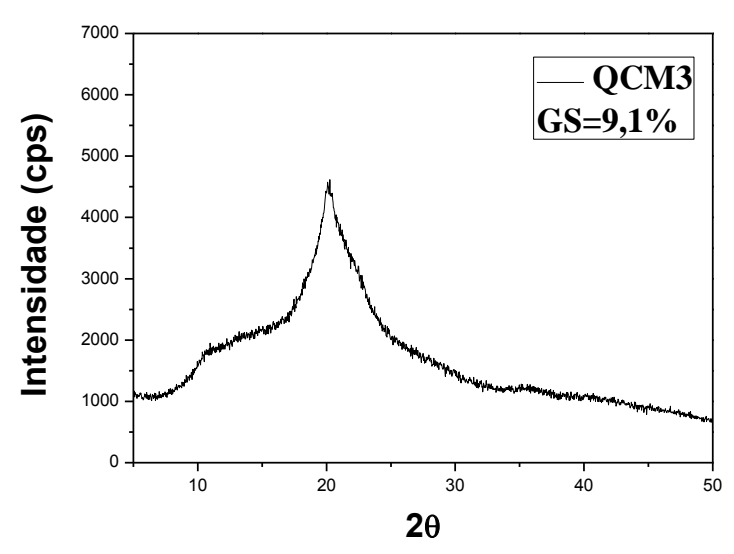

(c)

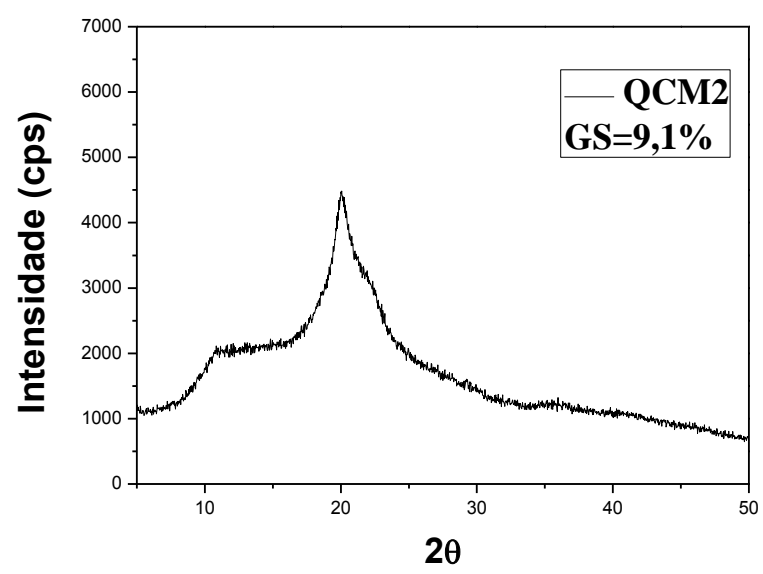

(b)

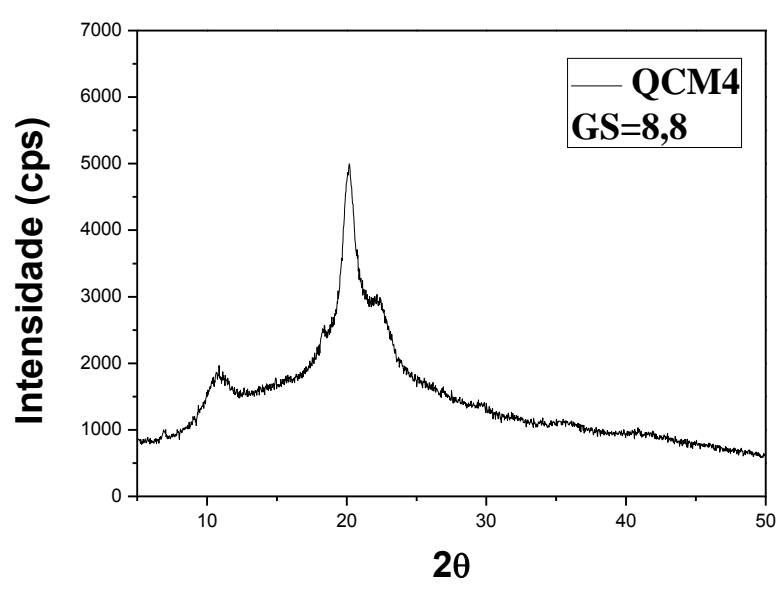

(d) 
Figura 17: Difratogramas das a mostras a) QD, QDM1 e QDM2; e b) QC, QCM3 e QCM4.

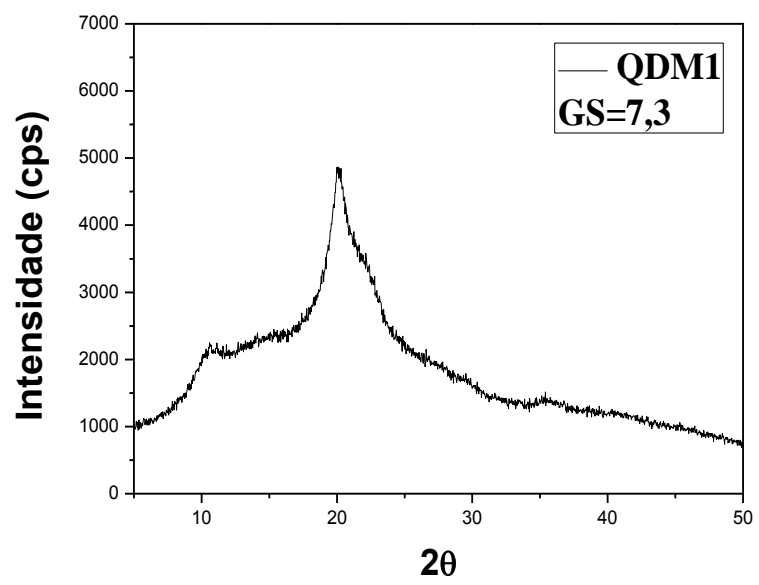

(a)

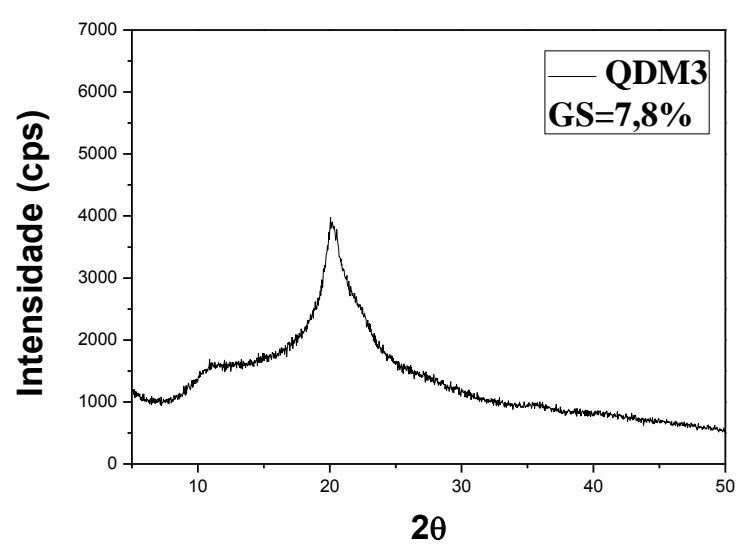

(c)

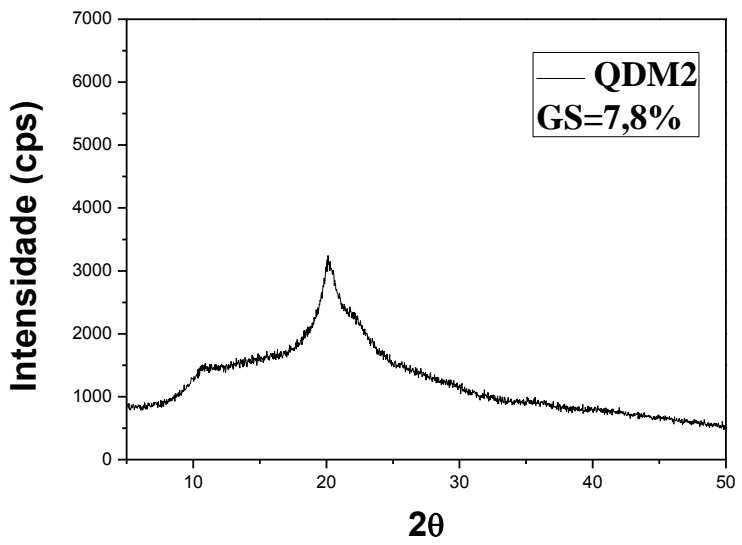

(b)

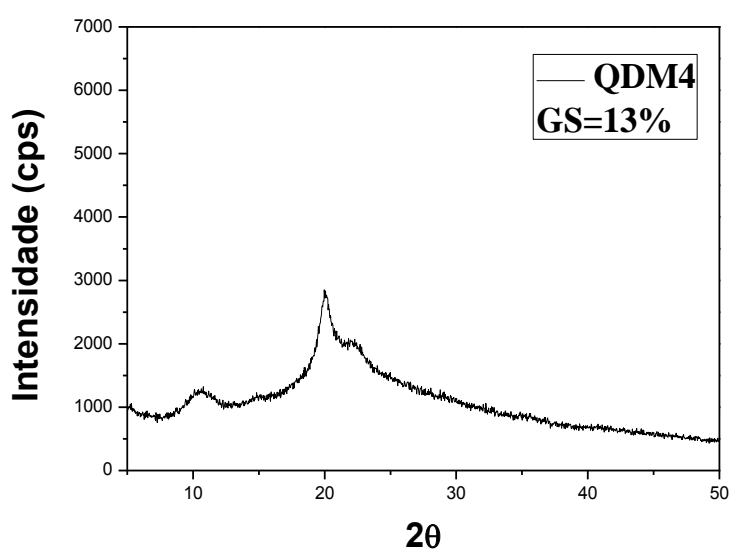

(d)

Os índices de cristalinidade (CrI) das amostras de quitosana e dos derivados QCMcx e QDMx foram calculados aplicando o método de Focher (BELTRAME; NAGGI; TORRI, 1990), corroborando a análise qualitativa dos difratogramas e revelando o efeito da reação de $O$-acilação sobre o arranjo das cadeias no estado sólido (Tabela 5). Assim, é observado que a diminuição da cristalinidade está relacionada ao aumento do grau de substituição dos derivados, o que pode ser atribuído ao desfavorecimento de estabelecimento de ligações hidrogênio, resultando em diminuição na cristalinidade (CHOI et al., 2007). Entretanto, nos casos das amostras mais substituídas (QCM4 e QDM4) é observado um aumento de cristalinidade, sugerindo a ocorrência de reorganização estrutural das cadeias, provavelmente devido ao 
estabelecimento de interações hidrofóbicas envolvendo as cadeias hidrocarbônicas do substituinte miristoíla (LE TIEN et al., 2003; CAI et al., 2015).

Tabela 5: Valores de índice de cristalinidade das amostras de quitosana Qc e QD e seus derivados com os respectivos valores de razão molar

\begin{tabular}{cccc}
\hline Amostra & $\begin{array}{c}\text { Razão } \\
\text { Molar Q/CM }\end{array}$ & $\overline{\mathbf{G S}}(\%)$ & $\mathbf{C r I}(\%)$ \\
\hline QC & - & - & 63,7 \\
QCM1 & $1: 0,075$ & 6,6 & 61,0 \\
QCM2 & $1: 0,1$ & 9,1 & 49,5 \\
QCM3 & $1: 0,2$ & 9,1 & 50,1 \\
QCM4 & $1: 0,5$ & 11 & 63,5 \\
\hline & & & \\
\hline QD & - & - & 52,7 \\
QDM1 & $1: 0,075$ & 7,3 & 51,0 \\
QDM2 & $1: 0.1$ & 7,8 & 47,6 \\
QDM3 & $1: 0,2$ & 7,8 & 53,2 \\
QDM4 & $1: 0,5$ & 13 & 57,5 \\
\hline
\end{tabular}

\subsubsection{Termogravimetria}

A partir das curvas de TG/DTG foi possível identificar três eventos distintos, sendo que o primeiro está associado ao processo de desidratação, o segundo é referente ao estágio de decomposição térmica e o terceiro é o resultante da decomposição oxidativa dos subprodutos das etapas anteriores (HOLME et al., 2001). As curvas TG/DTG das amostras de quitosana QC e QD, obtidas em atmosfera de ar sintético, são apresentadas na Figura 18.

Os teores de umidade das amostras de quitosana QC e QD foram determinados a partir do cálculo de perda de massa em relação à massa inicial, no intervalo de $25^{\circ} \mathrm{C}-110^{\circ} \mathrm{C}$. Os teores de umidade retida e a capacidade do polímero de absorver água estão relacionados à cristalinidade e à hidrofilicidade das amostras, sendo que as mais cristalinas retêm menos água que as amorfas, pois as regiões cristalinas limitam o acesso da água ou sua absorção. 
Figura 18- Curvas TG/DTG das amostras a) QC e b) QD, sob atmosfera dinâmica de ar sintético (vazão de gás $20 \mathrm{~mL} / \mathrm{min}$ ), massa da amostra $8 \mathrm{mg}$, suporte de amostra de platina.

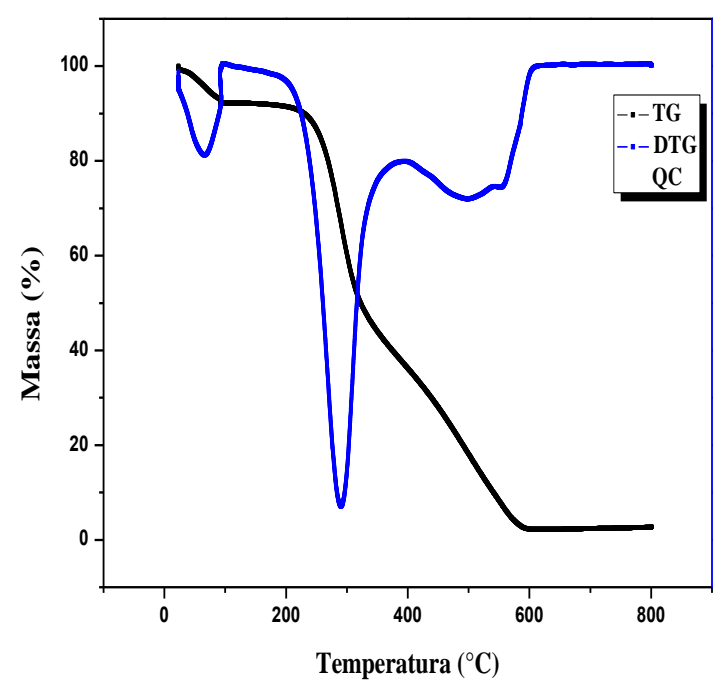

(a)

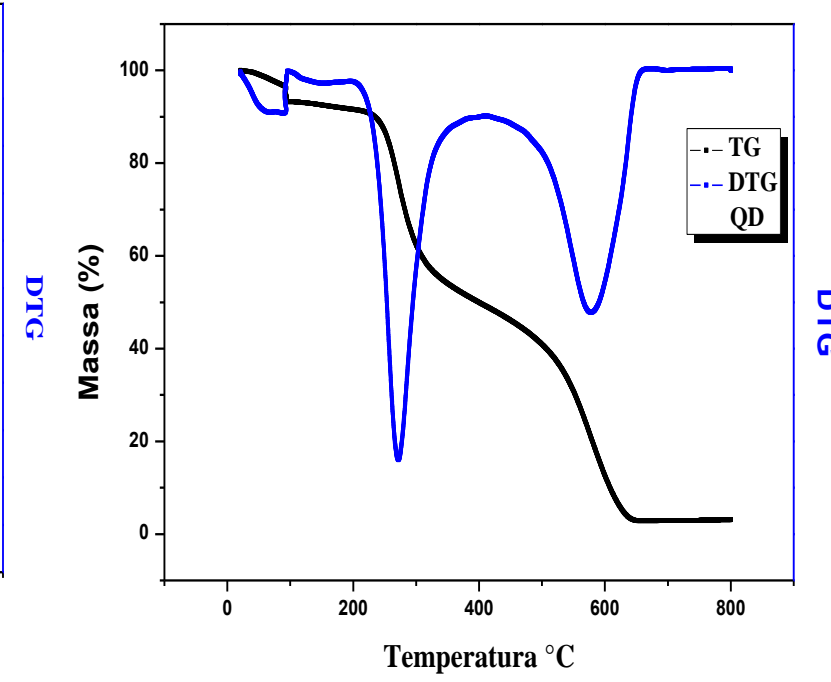

(b)

Os valores de perda de massa das quitosanas QC e QD durante o primeiro evento térmico $\left(25^{\circ} \mathrm{C}-110^{\circ} \mathrm{C}\right)$ não foram significativamente diferentes (Tabela 6), mostrando que tais amostras possuem capacidades semelhantes de absorver água.

Tabela 6: Valores de temperatura de desidratação relacionada ao primeiro evento das amostras de quitosana comercial (QC) e quitosana Daius (QD)

\begin{tabular}{rrccc}
\hline Amostra & $\overline{\boldsymbol{G A}}(\%)$ & $\begin{array}{c}\text { Intervalo de } \\
\text { temperatura }\left({ }^{\circ} \mathbf{C}\right)\end{array}$ & Tpico DTG $\left({ }^{\circ} \mathbf{C}\right)$ & Perda de massa (\%) \\
\hline QC & 5 & $25-110$ & 66 & 7 \\
QD & 15 & $25-110$ & 65 & 7 \\
\hline
\end{tabular}

A estabilidade térmica dos polímeros está ligada à flexibilidade das cadeias, pois à medida que a temperatura aumenta, as moléculas adquirem energia suficiente para romper as ligações intermoleculares, ou seja, quanto mais flexíveis forem as cadeias do polímero, maior sua mobilidade translacional, facilitando o deslizamento relativo das cadeias. O limite para degradação térmica situase no ponto em que as vibrações dos segmentos das cadeias adquirem tal amplitude que rompem as ligações interatômicas. Assim, as cadeias rígidas resistirão a essas vibrações mais fortes, sendo necessárias temperaturas mais altas para que ocorra a degradação térmica (ACKCELRUD, 2007). 
A análise dos dados relativos ao segundo evento térmico revela que a perda de massa no intervalo de $110-395{ }^{\circ} \mathrm{C}$ é maior no caso da amostra QC (Tabela 7). As estabilidades térmicas das amostras são avaliadas pelos valores de $\mathrm{T}_{\text {onset, }}$ temperatura que marca o início do processo de degradação, e, assim, é constatado que a amostra QC é termicamente a mais estável. Geralmente a diferença na perda de massa e a estabilidade térmica de diferentes quitosanas estão relacionadas à quantidade de unidades GlcNAc presentes nas cadeias (CORAZZARI et al., 2015), porém, nesse caso as diferenças de perdas de massa e de $\mathrm{T}_{\text {onset }}$ também podem estar relacionadas com a elevada massa molar da amostra QD.

Tabela 7: Valores de temperatura de decomposição relacionada ao segundo evento das amostras de quitosana comercial (QC) e quitosana Daius (QD)

\begin{tabular}{cccccc}
\hline Amostra & GS (\%) & $\begin{array}{c}\text { Intervalo de } \\
\text { temperatura }\left({ }^{\circ} \mathbf{C}\right)\end{array}$ & $\begin{array}{c}\text { Perda de } \\
\text { massa }(\%)\end{array}$ & Tonset $\left({ }^{\circ} \mathbf{C}\right)$ & $\begin{array}{c}\text { Tpico DTG } \\
\left({ }^{\circ} \mathbf{C}\right)\end{array}$ \\
\hline QC & 5 & $110-395$ & 51 & 251 & 290 \\
QD & 15 & $110-395$ & 45 & 247 & 272 \\
\hline
\end{tabular}

Nos casos das amostras dos derivados 3,6-O, $O^{\prime}$ - miristoilquitosana também foi observado que os teores de umidade não foram significativamente diferentes $(7 \%-9 \%)$, indicando semelhança entre os derivados QCMx e QDMx e em relação às quitosanas de partida (Tabela 8).

Tabela 8- Valores de temperatura de desidratação térmica curva DTG e perda de massa curva TG das amostras aciladas

\begin{tabular}{ccccc}
\hline Amostra & GS (\%) & $\begin{array}{c}\text { Intervalo de } \\
\text { temperatura }\left({ }^{\circ} \mathbf{C}\right)\end{array}$ & Tpico DTG $\left({ }^{\circ} \mathbf{C}\right)$ & $\begin{array}{c}\text { Perda de massa } \\
(\%)\end{array}$ \\
\hline QC & - & $25-110$ & 66 & 7 \\
QCM1 & 6,2 & $25-110$ & 55 & 7 \\
QCM2 & 9,1 & $25-110$ & 67 & 8 \\
QCM3 & 9,1 & $25-110$ & 62 & 8 \\
QCM4 & 8,6 & $25-110$ & 68 & 8 \\
\hline QD & - & $25-110$ & 65 & 7 \\
QDM1 & 7,3 & $25-110$ & 65 & 8 \\
QDM2 & 7,8 & $25-110$ & 63 & 9 \\
QDM3 & 7,8 & $25-110$ & 52 & 8 \\
QDM4 & 13 & $25-110$ & 49 & 9 \\
\hline
\end{tabular}


O segundo evento observado nas curvas TG dos derivados QCMx e QDMx ocorre no intervalo $110-395{ }^{\circ} \mathrm{C}$. A partir desses dados foi possível notar que para os derivados QCMx e QDMx, a presença dos substituintes miristoíla resultou em polímeros termicamente menos estáveis quando comprados com as quitosanas de partida, o que é constatado pelos valores de $\mathrm{T}_{\text {onset }}$ (Tabela 9). Quando os valores de $\mathrm{T}_{\text {onset }}$ dos derivados QCMx e QDMx são comparados com os das quitosanas de partida (Tabela 7) é possível concluir que as quitosanas de partida são termicamente mais estáveis, o que pode ser justificado pela presença dos grupamentos miristoíla nas cadeias dos derivados, que prejudica o estabelecimento de ligações hidrogênio (MA et al., 2009; ELKHOLY et al., 2014).

Tabela 9: Valores de temperatura de decomposição relacionada ao segundo evento térmico das amostras dos derivados derivados 3,6-O, $O^{\prime}$ - miristoilquitosana(QCMx e QCDx)

\begin{tabular}{ccccc}
\hline Amostra & $\overline{\boldsymbol{G S}}(\boldsymbol{\%})$ & $\begin{array}{c}\text { Intervalo de } \\
\text { temperatura }\left({ }^{\circ} \mathbf{C}\right)\end{array}$ & $\begin{array}{c}\text { Perda de massa } \\
(\boldsymbol{\%})\end{array}$ & Tonset $\left({ }^{\circ} \mathbf{C}\right)$ \\
\hline QC & - & $110-395$ & 51 & \\
QCM1 & 5,2 & $110-395$ & 57 & 251 \\
QCM2 & 8,2 & $110-395$ & 54 & 230 \\
QCM3 & 8,9 & $110-395$ & 58 & 230 \\
QCM4 & 9,7 & $110-395$ & 60 & 224 \\
\hline QD & - & $110-395$ & 45 & 247 \\
QDM1 & 6,6 & $110-395$ & 46 & 266 \\
QDM2 & 8,2 & $110-395$ & 53 & 231 \\
QDM3 & 8,6 & $110-395$ & 56 & 235 \\
QDM4 & 10,5 & $110-395$ & 51 & \\
\hline
\end{tabular}

Os dados relativos ao segundo evento térmico revelam que os derivados QCMx e QDMx apresentaram valores de perda de massa maiores (Tabela 9) que as quitosanas de origem (Tabela 8). A partir das curvas TG/DTG (Figura 19) é possível observar que à medida que o grau de substituição dos derivados aumenta, as respectivas curvas DTG passam a apresentar indicações da ocorrência de dois eventos no intervalo de temperatura $110-395{ }^{\circ} \mathrm{C}$. Assim, esse comportamento está bem evidenciado nos casos QCM3 e QCM4 porém não é observado nos casos das outras amostras do derivado $O, O^{\prime}$-dimiristoilquitosana (Figura 20), independentemente da quitosana de partida. 
Figura 19: Curvas TG/DTG dos derivados da quitosana QC a) QCM1; b) QCM2; c) QCM3 e d) QCM4, sob atmosfera dinâmica de ar sintético (vazão de gás $20 \mathrm{~mL} / \mathrm{min}$ ), massa da amostra $8 \mathrm{mg}$, suporte de amostra de platina.

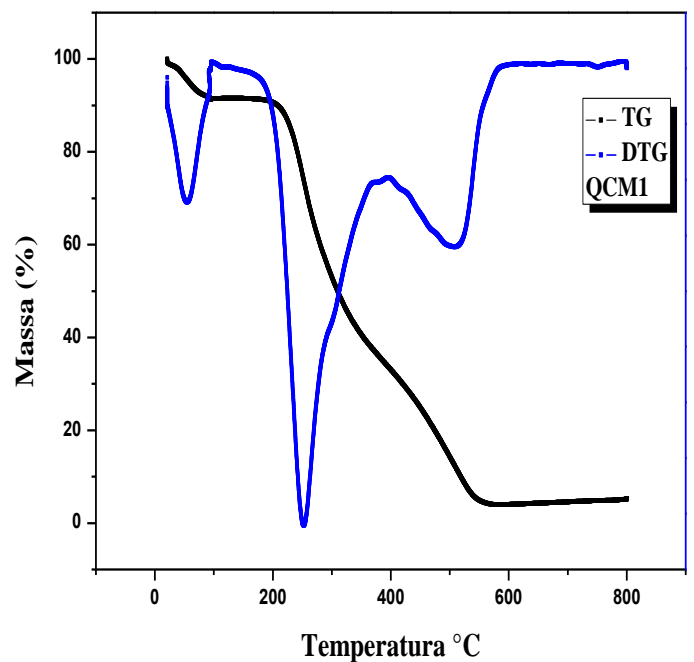

(a)

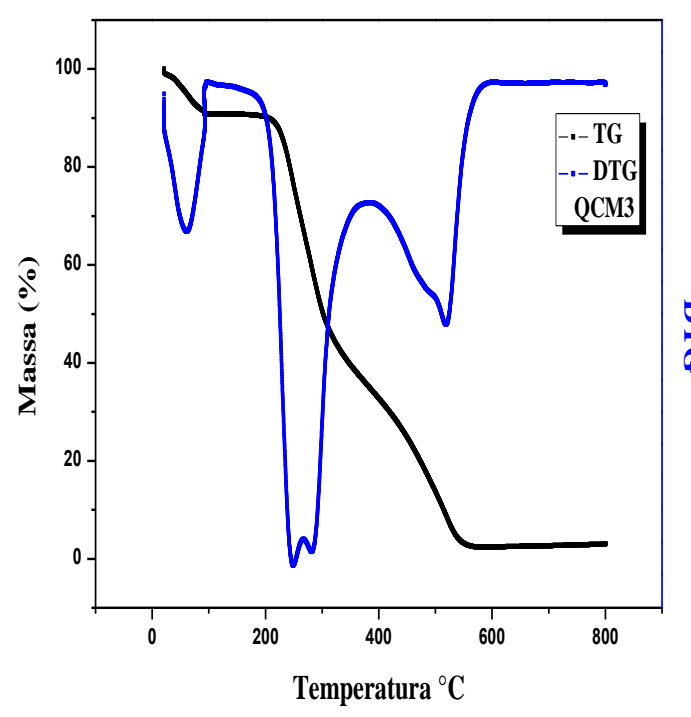

(c)

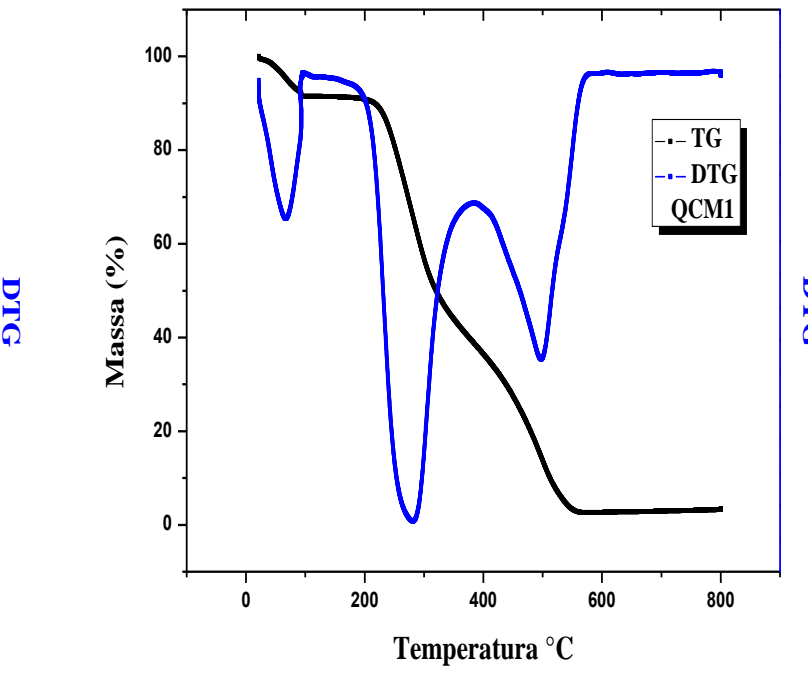

(b)

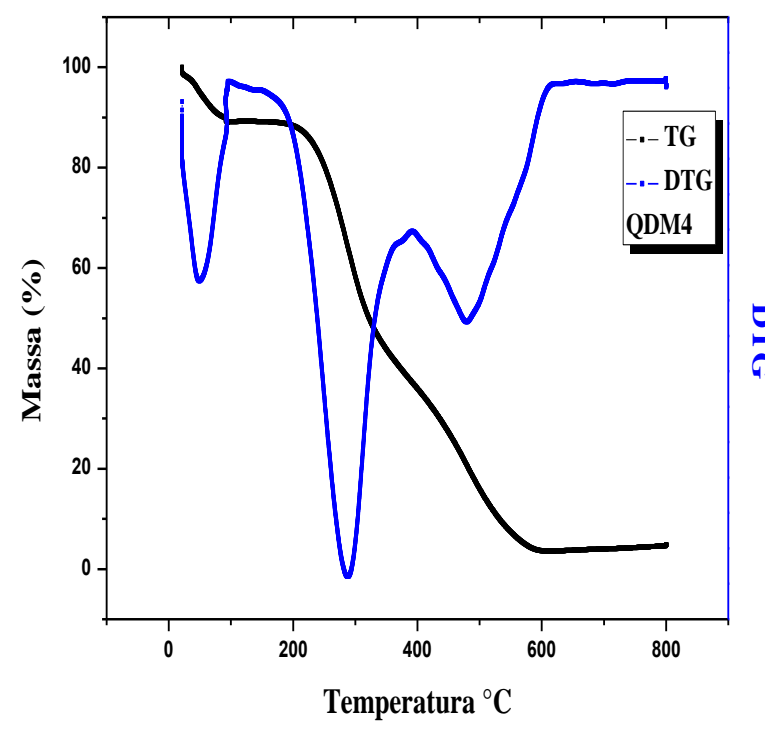

(d) 
Figura 20: Curvas TG/DTG dos derivados da quitosana QD a) QDM1; b) QDM2; c) QDM3 e d) QDM4, sob atmosfera dinâmica de ar sintético (vazão de gás $20 \mathrm{~mL} / \mathrm{min}$ ), massa da amostra $8 \mathrm{mg}$, suporte de amostra de platina.

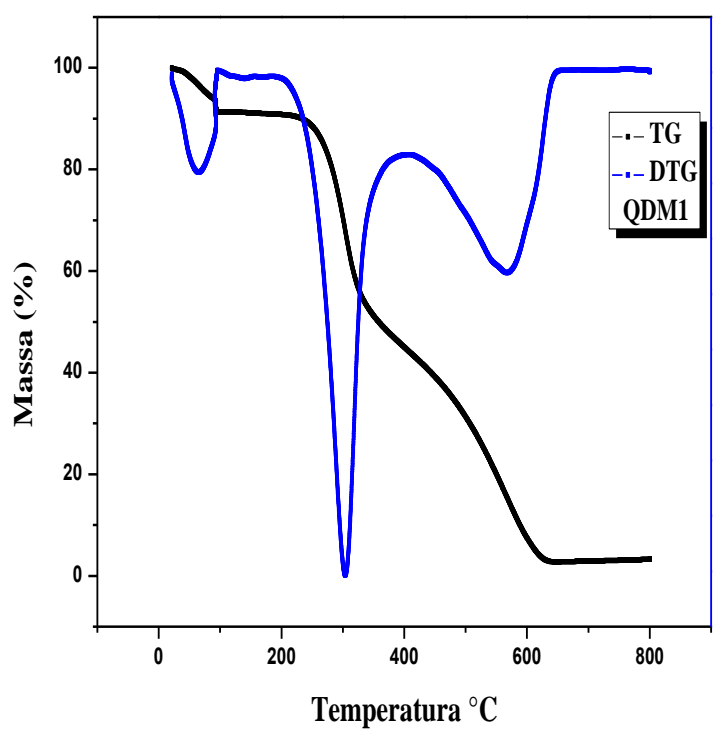

(a)

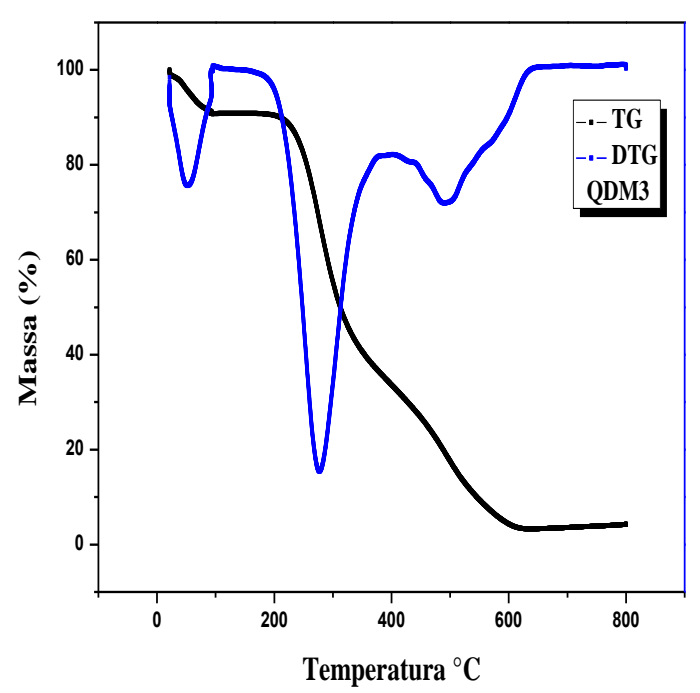

(c)

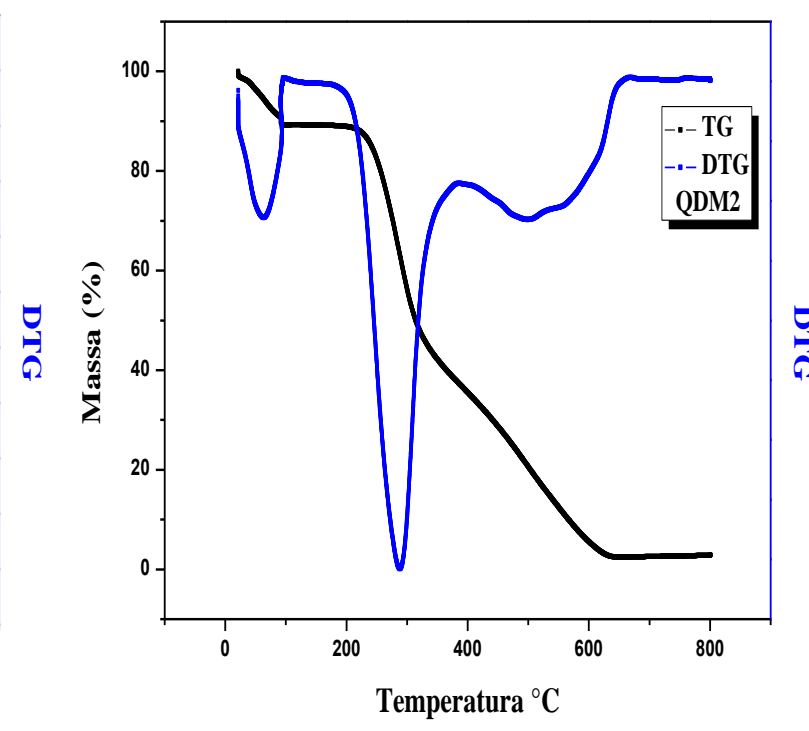

(b)

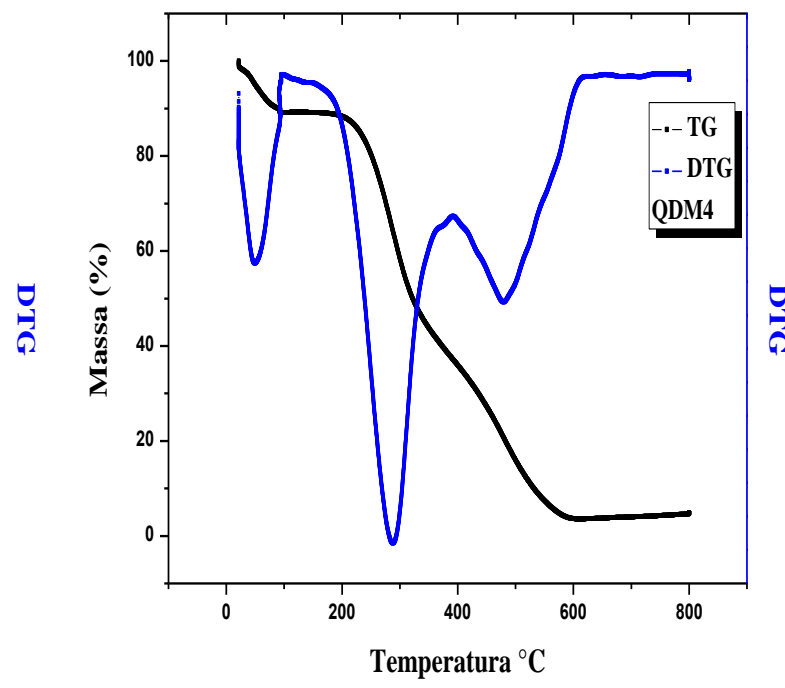

(d)

\subsubsection{Solubilidade}

A determinação da solubilidade em água das quitosanas e das amostras QCMx e QDMx em função do pH foi baseada na turbidez de suas soluções, através das análises de UV-visível.

Foi observado que as solubilidades das amostras QCM1 e QDM1 são representativas do 
conjunto de amostras de derivados acilados, e que todas as amostras se apresentaram solúveis e insolúveis nas mesmas faixas de $\mathrm{pH}$ (Figura 21).

Figura 21: Gráfico do $\mathrm{pH}$ versus transmitância (comprimento de onda de $600 \mathrm{~cm}^{-1}$ ) das soluções de quitosana e dos derivados 3,6-O, $O^{\prime}$ - miristoilquitosana.

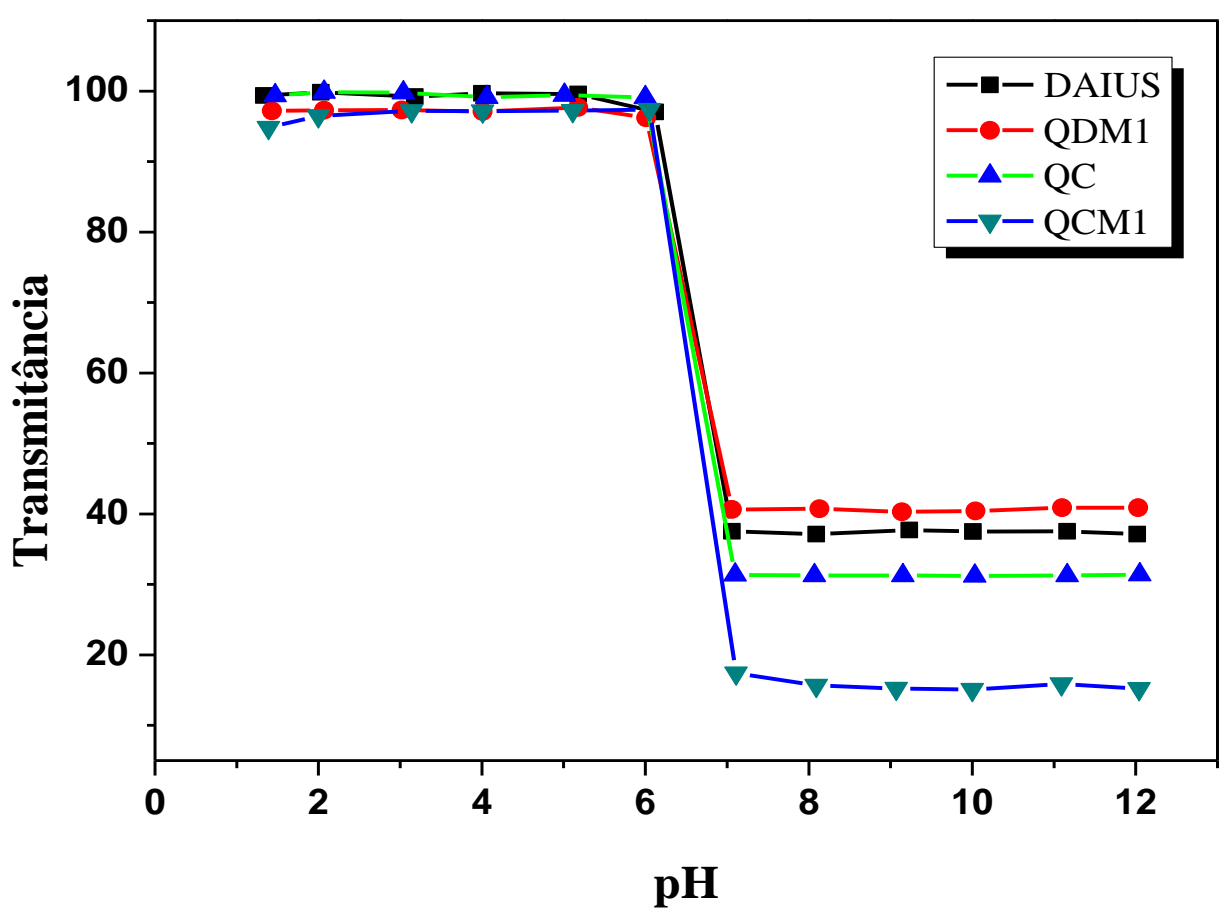

Conforme apresentado na Figura 21, foi observado que todas amostras foram solúveis até $\mathrm{pH}=6$, a solubilidade na região ácida deve ser atribuída à protonação dos grupos amino $\left(-\mathrm{NH}_{2} /-\mathrm{NH}_{3}{ }^{+}\right)$, enquanto que a partir do $\mathrm{pH}=7$ houve uma diminuição dos valores de transmitância como consequência da desprotonação dos sítios amônio, o que leva à diminuição da solubilidade e à presença de material particulado na suspensão. $\mathrm{O}$ valor referência utilizado para diferenciar as faixas de $\mathrm{pH}$ em que as amostras foram solúveis foi para transmitância $<80 \%$.

\section{Caracterizaç̃o dos derivados escolhidos para aplicação}

Mediante os resultados discutidos acima, as próximas análises foram realizadas apenas para as amostras de interesse para continuidade dos estudos de micelização e encapsulação de fármacos hidrofóbicos, aplicados no tratamento de câncer. Os derivados selecionados foram os originados da quitosana comercial, por se tratar de uma quitosana com menor massa molar 
média viscosimétrica $(\overline{M v}=87 \mathrm{kDa})$, em virtude da influência da massa molar sobre a concentração micelar crítica (CMC). O aumento da massa molar para polímeros que mantém constante a quantidade de segmentos hidrofóbicos e hidrofílicos conduz a diminuição na CMC, e por consequência dessa diminuição, as propriedades físicas das micelas poliméricas, tais como morfologia, tamanho e estabilidade, são comprometidas (CROY; KWON, 2006). Portanto, os derivados QCM1 e QCM4 foram escolhidos dentre os derivados obtidos da quitosana comercial, sendo que estes foram selecionados a fim de avaliar a influência dos $\overline{G S}$ sobre as propriedades das micelas.

\subsubsection{Molhabilidade}

As medidas de ângulo de contato empregados em água como sonda foram realizadas a fim de investigar o comportamento de molhabilidade da quitosana e dos derivados QCM1 e QCM4 e assim avaliar o efeito hidrofóbico causado pela presença dos grupos miristoíla e então comparar com a quitosana de partida.

Conforme observado na Figura 22 a quitosana exibiu um valor de ângulo de contato de $18^{\circ}$, resultado característico de sua alta hidrofilicidade, fato que pode ser atribuído ao caráter hidrofílico da quitosana devido a presença dos grupos amino e hidroxila.(CHEN et al., 2013). Por outro lado, os valores de ângulos de contato dos derivados QCM1 e QCM4 foram de $60^{\circ} \mathrm{e}$ $107^{\circ}$, revelando um aumento de hidrofobicidade das amostras quando comparado a quitosana de partida, confirmando que a presença dos grupos miristó́la são os principais responsáveis pelo caráter hidrofóbico dos derivados. De fato, os resultados obtidos também revelam que quanto maior o teor de substituintes miristoíla, maior os valores de ângulo de contato e, portanto, maior a hidrofobicidade das amostras. 
Figura 22: Imagens de ângulo de contato em água faz amostras de (A) quitosana, (B) QCM1 e (C) QCM4.

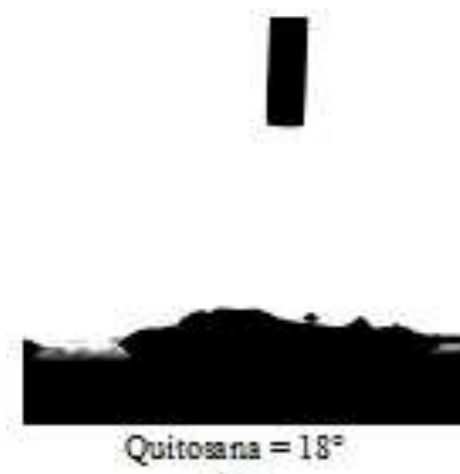

(A)

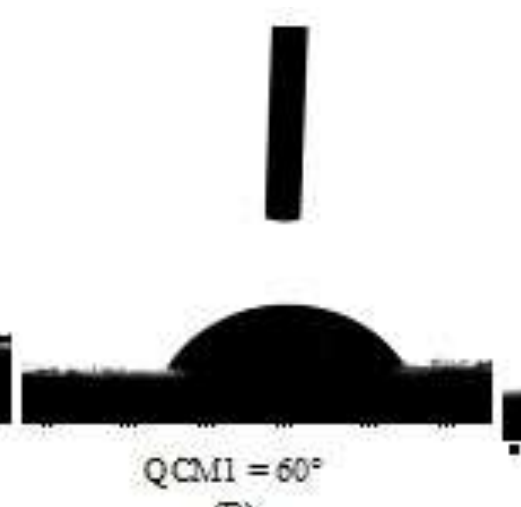

(B)

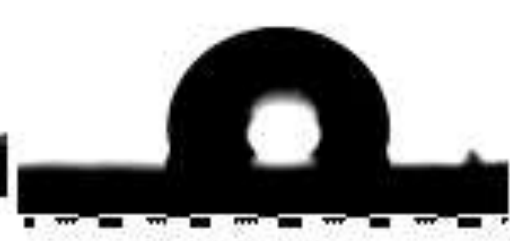

$\mathrm{QCM} 4=107^{\circ}$

(C)

\subsubsection{Concentração micelar crítica (CMC)}

Micelas poliméricas comportam-se de forma semelhante aos surfactantes e estas têm-se mostrado adequadas para liberação de fármacos. Além disso, também são caracterizadas pela sua natureza química distinta, constituída por segmentos hidrofóbicos e hidrofílicos. Como as propriedades dos segmentos são visivelmente diferentes, em solução aquosa os segmentos hidrofóbicos são fracamente solúveis, enquanto que os hidrofílicos são altamente solúveis. O resultado dessa diferença de solubilidade dos segmentos é a principal causa da micelização, processo capaz de formar estruturas nanométricas conhecidas como micelas (CROY; KWON, 2006).

As micelas são formadas pelo resultado de forças atrativas que levam à associação de moléculas e forças repulsivas que impedem o crescimento ilimitado das micelas para uma fase macroscópica distinta (PRICE, 1983; ASTAFIEVA; ZHONG; EISENBERG, 1993). A ocorrência de micelização e a determinação da concentração micelar crítica podem ser estudadas por técnicas como dispersão dinâmica da luz, tensão superficial e espectroscopia de fluorescência, porém, também pode ser investigada por análise condutimétrica, técnica simples, rápida e de baixo custo, que apresenta resultados reprodutíveis e comparáveis aos adquiridos usando as outras técnicas. Sendo assim, as soluções aquosas das amostras QCM1 e QCM4 foram preparadas e avaliadas por condutividade, a fim de identificar a ocorrência de agregação macromolecular. 
Assim, os valores de CMC das amostras QCM1 e QCM4 foram determinados a partir das curvas de condutividade específica $\left(\mu \mathrm{S} \mathrm{cm}^{-1}\right)$ versus $\log [\mathrm{Cp}]$, onde $\mathrm{Cp}$ é a concentração de polímero $\left(\mathrm{mg} \mathrm{mL}^{-1}\right)$, na intersecção entre as retas correspondentes aos ramos da curva em concentrações poliméricas baixas $\left(\mathrm{Cp} \leq 10^{-3} \mathrm{mg} \mathrm{mL}^{-1}\right)$ e elevadas $\left(\mathrm{Cp} \geq 10^{-2} \mathrm{mg} \mathrm{mL}^{-1}\right)$. As curvas de condutividade específica versus $\log [\mathrm{Cp}]$ correspondentes às amostras QCM1e QMC4 (Figura 23), mostramos dois ramos lineares, conforme mencionado a cima. No ramo, i.e. em baixas concentrações poliméricas, o aumento da condutividade da solução com o aumento da concentração de polímero se deve ao aumento da concentração das cadeias positivamente carregadas, devido à presença dos grupos amônio distribuídos ao longo das cadeias do polímero, à medida que a concentração do polímero é aumentada. Na segunda parte da curva de condutividade específica versus $\log [\mathrm{Cp}]$, o meio é saturado com micelas e a adição de mais cadeias carregadas contribui para aumento da condutividade da solução e como as micelas já estão formadas, essas não são capazes de agregar novas cadeias de polímero.

Portando, de acordo com as curvas apresentadas na Figura 23 os valores de CMC das

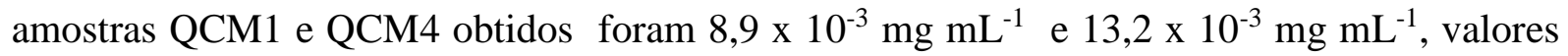
inferiores aos de tensoativos de baixa massa molecular, tal como dodecilsulfato de sódio (CMC = 2,3 $\mathrm{mg} \mathrm{mL}^{-1}$ ), ou seja mais estáveis que alguns tipos de surfactantes (LEE et al., 1998). 
Figura 23: Curva da condutividade especifica versus a função logarítma da concentração das amostras DCM1 e DCM4 no intervalo de $1 \mathrm{mg} / \mathrm{mL}$ a $1.10^{-6} \mathrm{mg} / \mathrm{mL}$.

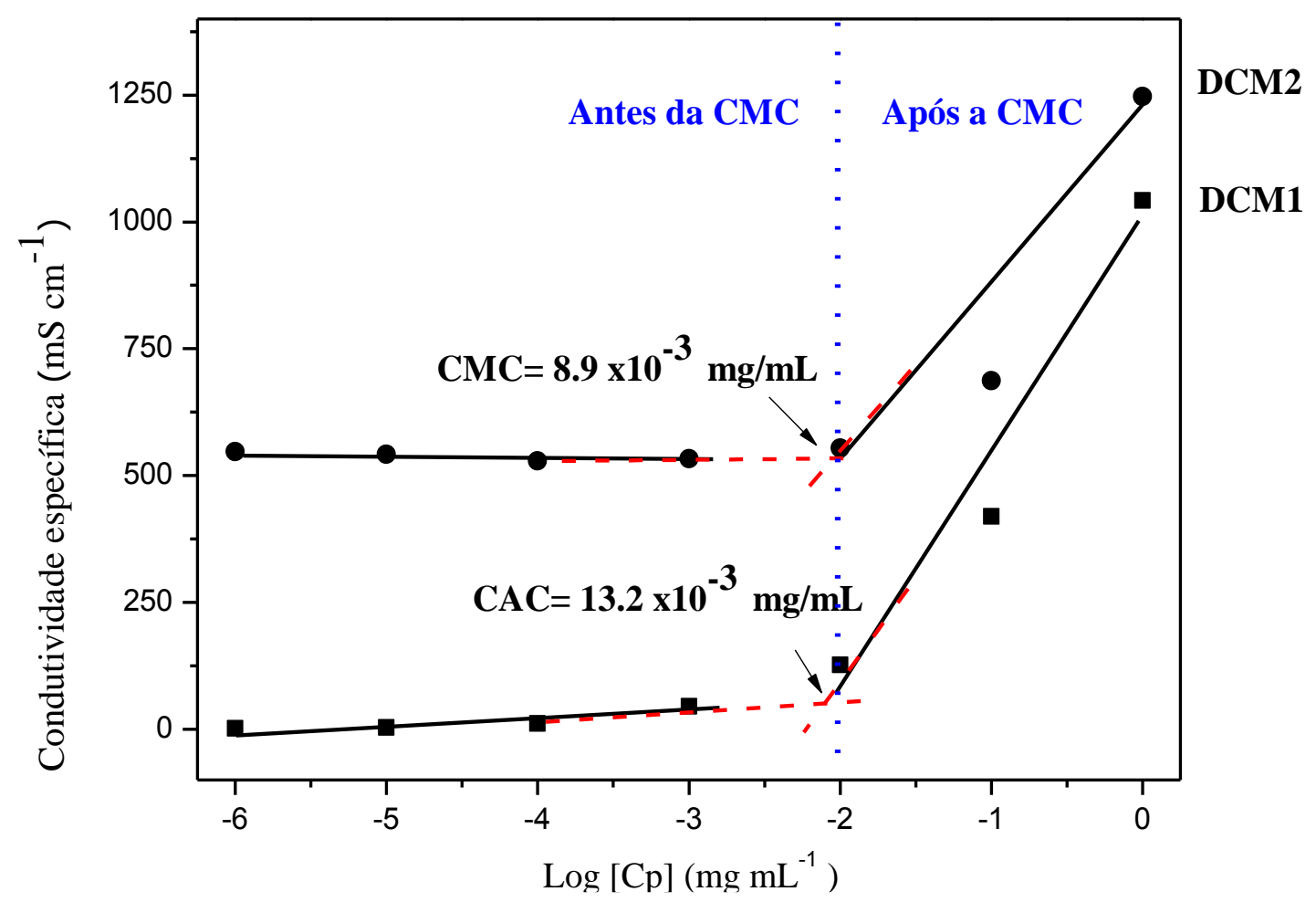

Sistemas micelares são formados quando a concentração do polímero anfifílico é superior a um valor crítico, conhecido como concentração crítica de agregação, e a partir desse valor é possível avaliar a estabilidade das micelas (HUO et al., 2011). A capacidade das micelas suportarem a diluição é descrita em termos da sua estabilidade termodinâmica, sendo que micelas com valores de CMC baixos podem se manter em uma solução mais diluída e, assim sendo, termodinamicamente mais estáveis (CROY; KWON, 2006), comportamento observado nas micelas dos derivados QCM1 e QCM4 quando comparados a surfactantes.

\subsubsection{Conclusão}

A síntese e caracterização dos derivados 3,6-O, $O^{\prime}$ - miristoilquitosana obtidos via $O$ acilação a partir de quitosanas comercial e DAIUS utilizando cloreto de miristó́la foi realizada com êxito. As caracterizações confirmam a obtenção do derivado desejado com a inserção do grupo acila nos grupos $\mathrm{OH}$ da quitosana. Os espectros de FTIR evidenciaram a ocorrência da 
reação de através da presença da banda observada em $1740 \mathrm{~cm}^{-1}$. Reações de $N$-acilação não foram observadas. Os espectros de $\mathrm{RMN}{ }^{1} \mathrm{H}$ mostraram a ocorrência da acilação a partir dos sinais do grupo miristoíla em 0,9 ppm referente aos hidrogênios do grupo metila $\left(\mathrm{CH}_{3}\right), 1,3$ ppm aos hidrogênios dos grupos metileno $\left(-\mathrm{CH}_{2}-\right), 1,7$ ppm hidrogênios do metileno do carbono $\beta$ e 2,3 ppm aos hidrogênios referentes ao metileno do carbono $\alpha$. Não foram identificados sinais de $N$-substituição. A partir dos difratogramas e das análises termogravimétricas dos derivados foi possível notar que esses apresentaram índices de cristalinidade menores e menor estabilidade térmica quando comparados às quitosanas de partida. A partir do teste de solubilidade, foi possível observar que a quitosana e os derivados apresentam-se solúveis em $\mathrm{pH} \leq 6,5$. Os resultados de ângulo de contato confirmaram a presença de grupos hidrofílicos na quitosana e grupos hidrofóbicos nos derivados e estes resultados também foram confirmados pelas medidas de CMC, que permitiram avaliar a formação das micelas a partir dos derivados, que só apresentam essa capacidade de micelizar devido a presença dos grupos hidrofóbicos e hidrofílicos. Com os resultados obtidos foi possível finalizar a etapa de produção dos derivados anfifílicos de quitosana, no qual foram produzidos e caracterizados com intuito de aplicar na encapsulação e liberação de fármacos antitumorais. 


\subsection{Parte 2: Estudos de encapsulação e liberação de paclitaxel (PTX)}

\subsubsection{Eficiência de Encapsulação}

A capacidade de encapsulação de paclitaxel (PTX) pelos sistemas micelares à base dos derivados QCM foram avaliadas pelo método de HPLC. A quantificação foi realizada através do método indireto, ou seja, a partir do sobrenadante, fase em que se encontra o PTX não encapsulado. Esse método foi usado devido à dificuldade de destruir as micelas e assim quantificar por método direto a carga de fármaco efetivamente encapsulado. A curva analítica foi elaborada com a finalidade de verificar a viabilidade de quantificar PTX através do método proposto.

Por meio da análise dos resultados apresentados na Figura 24, foi observado uma correlação linear $\left(r^{2}=0,9996\right)$ entre a área do pico no HPLC com absorbância em $227 \mathrm{~nm}$ e as concentrações de PTX no intervalo de 0,5 a $100 \mu \mathrm{g} / \mathrm{mL}$, no tempo de retenção de 7,9 minutos. A partir dos dados apresentados foi possível concluir que o método mostrou linear em toda faixa de concentração estudada.

Os valores de eficiência de encapsulação (EE) foram calculados a partir da equação da reta obtida a partir curva analítica e os resultados são apresentados na Tabela 10.

A capacidade de encapsulação dos dois sistemas micelares à base de QCM foram de $100 \%$, revelando que não houve nenhuma influência do $\overline{G S}$ sobre a capacidade de encapsulação de PTX. Adicionalmente, foi observado que todos os sistemas permaneceram estáveis, não havendo formação de partículas maiores e/ou precipitação de partículas. 
Figura 24: Curva analítica da área dos picos dos cromatogramas em função da concentração de PTX.

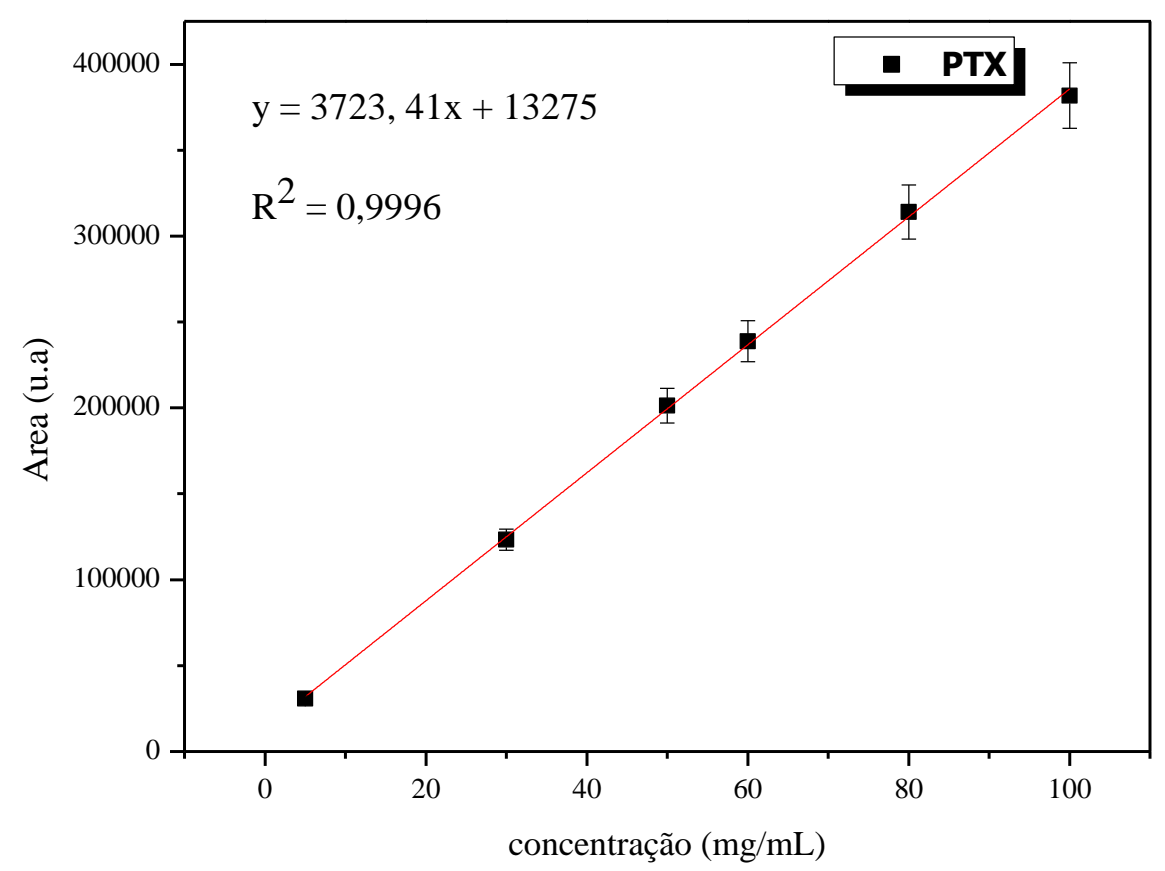

\subsubsection{Tamanho e morfologia}

No que diz respeito à estabilidade e às propriedades biológicas de sistemas nanoestruturados, as características físico-químicas, tais como diâmetro médio, índice de polidispersão (PDI) e o potencial zeta são parâmetros de extrema importância. Com relação à influência desses parâmetros, as dimensões nanométricas dos sistemas micelares têm influência direta sobre a capacidade de penetrarem através das barreiras fisiológicas, sendo que a distribuição média dos tamanhos das micelas é um dos fatores responsáveis pela estabilidade das formulações enquanto o potencial zeta é importante tanto para a estabilidade quanto para o reconhecimento do sistema imunológico e distribuição das nanopartículas após administração (MCCARRON; WOOLFSON; KEATING, 1999; TAVARES, 2013).

Diante disso, as micelas vazias e carregadas com PTX foram caracterizadas de acordo com o diâmetro médio, o índice de polidispersão e o potencial zeta (Tabela 10). 
Tabela 10: Dados das caracterizações das micelas à base de QCM relativamente a diâmetro médio, índice de polidispersividade, potencial zeta e eficiência de encapsulação

\begin{tabular}{|c|c|c|c|c|c|c|c|c|}
\hline \multirow{3}{*}{$\begin{array}{r}\text { PTX } \\
(\%)\end{array}$} & \multicolumn{8}{|c|}{ Micelas - PTX } \\
\hline & \multicolumn{4}{|c|}{ Amostra QCM1 } & \multicolumn{4}{|c|}{ Amostra QMC4 } \\
\hline & Diâmetro $(\mathbf{n m})^{1 \#}$ & $\mathbf{P D I}^{2 \#}$ & Zeta $(\mathrm{mV})^{3}$ & $\mathrm{EE}(\%)^{4}$ & Diâmetro $(\mathbf{n m})^{1 \#}$ & PDI $^{2 \#}$ & $\operatorname{Zeta}(\mathrm{mV})^{3}$ & $\mathrm{EE}(\%)^{4}$ \\
\hline 2 & $482 \pm 91$ & $0.5 \pm 0.1$ & $35 \pm 5$ & $100^{*}$ & $373 \pm 25$ & $0.2 \pm 0.02$ & $44 . \pm 0.8$ & $100 \pm 13$ \\
\hline 1 & $332 \pm 42$ & $0.5 \pm 0.05$ & $36 \pm 3$ & $100^{*}$ & $493 \pm 78$ & $0.3 \pm 0.01$ & $42 \pm 1$ & $96 \pm 8$ \\
\hline 0.5 & $347 \pm 20$ & $0.4 \pm 0.08$ & $36 \pm 1$ & $100 *$ & $342 \pm 81$ & $0.5 \pm 0.03$ & $36 \pm 3$ & $100 \pm 1$ \\
\hline 0.1 & $290 \pm 7$ & $0.5 \pm 0.1$ & $36 \pm 3$ & $100 *$ & $287 \pm 36$ & $0.5 \pm 0.1$ & $36 \pm 3$ & $100 \pm 1$ \\
\hline 0 & $356 \pm 21$ & $0.5 \pm 0.03$ & $32 \pm 4$ & - & $462 \pm 10$ & $0.5 \pm 0.04$ & $34 \pm 2$ & - \\
\hline
\end{tabular}

Diâmetro $^{1}$, polidispersividade ${ }^{2}$ e potencial zeta ${ }^{3}$ foram determinados por espalhamento de luz dinâmico (DLS). A porcentagem de PTX- eficiência de encapsulação ${ }^{4}$ * Abaixo do limite de detecção por HPLC. Os valores foram relatados como média \pm DP $(n=3)$. \# Todas as formulações apresentaram perfil monomodal. 


\subsubsection{Diâmetro médio}

O diâmetro médio das micelas QCM1 variaou de 287 nm a 490 nm (Tabela 10), sendo que as micelas do derivado QCM4 não carregadas com PTX exibiram valores maiores que as micelas de QCM1 não carregadas, provavelmente devido aos valores de $\overline{G S}$ maiores no caso do derivado QCM4, o que possivelmente resultou na expansão do volume das micelas para alojar os grupos hidrofóbicos no seu interior.

Os diâmetros médios das micelas com baixo conteúdo de PTX $(0,1 \%$ e $0,5 \%)$ foram semelhantes, independentemente de serem compostas por QCM1 ou QCM4, mas o aumento da carga de PTX (até 2\%) resultou em uma contração de volume no caso das micelas de QCM4, enquanto que as micelas de QCM1 exibiram uma expansão de volume em comparação com as micelas vazias correspondentes. Esse comportamento pode ser atribuído aos diferentes valores de grau de substituição das amostras QCM1 e QCM4, sendo que para o primeiro caso o baixo conteúdo de frações hidrofóbicas no interior das micelas desfavorece as interações polímero/fármaco, resultando em uma expansão de volume, enquanto essas interações são favorecidas no último caso devido ao maior teor de substituintes miristoíla nas cadeias de QCM4 e, consequentemente, observa-se uma contração de volume.

Segundo Sarmento e coautores, nanopartículas com tamanhos médios inferiores a $1000 \mathrm{~nm}$ são indicadas para administração oral, pois melhoram a absorção e, dependendo de suas características físico-químicas, esses sistemas podem atravessar barreiras biológicas, serem fagocitadas e internalizadas (SARMENTO et al., 2007). Portanto, a partir dos resultados de diâmetro médio pode-se afirmar que tais micelas são promissoras para administração de fármacos hidrofóbicos via administração oral. 


\subsubsection{2. Índice de polidispersividade}

O índice de polidispersividade (PDI) refere-se à medida da amplitude de distribuição de tamanho de partículas, o qual pode variar de 0 a 1 . A partir dos dados de PDI, é possível verificar se o sistema é monodisperso, e de acordo com a literatura formulações com valores $\mathrm{PDI} \leq 0,3$ apresentam tal característica (RAO; GECKELER, 2011; HICKEY et al., 2015).

No que diz respeito aos resultados de PDI das micelas, foi possível observar que os valores variaram de 0,21 a 0,52, indicando que os sistema não apresentaram uma distribuição monodispersa, apesar de apresentarem distribuição monomodal (Figura 25), fato que pode ser justificado pela distribuição não-uniforme dos grupos acila adicionados às cadeias de quitosana, por se tratar de um derivado proveniente de uma reação heterogênea, que leva à distribuição em bloco dos grupos substituintes. Contudo, os valores obtidos estão de acordo com os resultados obtidos na literatura para derivados de quitosana (ZHANG et al., 2003; ZHANG; QINENG; ZHANG, 2004; YUAN et al., 2010; ALMEIDA et al., 2017).

Figura 25: Gráfico de distribuição de tamanho por intensidade de espalhamento de luz da QCM1 com $2 \%$ de PTX, representativo para todas as demais amostras.

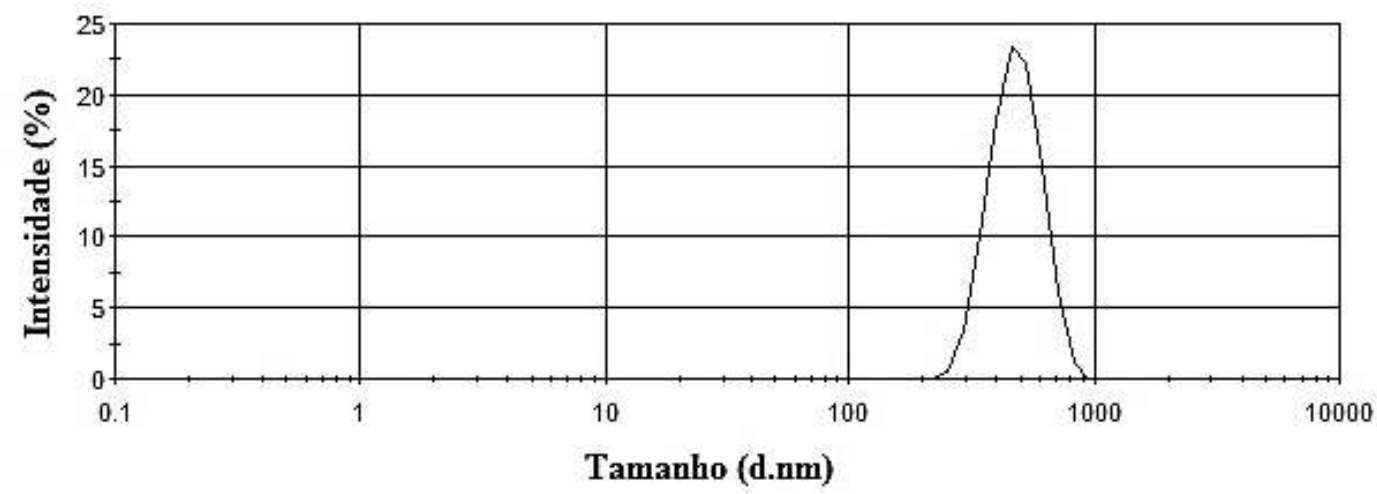

\subsubsection{Potencial zeta}

A medida do potencial zeta de superfícies de partículas e micelas suspensas em um determinado meio permite avaliar a estabilidade, à medida que as forças eletrostáticas 
repulsivas atuem entre as espécies igualmente carregadas e contribuem para a estabilização destes sistemas (HUO et al., 2011).

De acordo com os dados apresentados na Tabela 10, as micelas carregadas e vazias apresentaram valores de potencial zeta positivos e elevados $(>+30 \mathrm{mV})$, independentemente de serem compostas por QCM1 ou QCM4, o que pode ser atribuído ao elevado teor de grupos amônio, pertencentes aos segmentos das cadeias principais do polímero, que se encontram na superfície das micelas. Tal valor é similar aos valores encontrados por Almeida e colaboradores, que relataram a produção de micelas de quitosana enxertada com policaprolactona carregadas com PTX, as quais também apresentaram os grupos amino da quitosana expostos na superfície das micelas (ALMEIDA et al., 2017).

Os valores de potencial zeta das micelas QCM1 vazias e carregadas foram ligeiramente diferentes, enquanto que no caso das micelas de QCM4 observou-se um aumento do potencial zeta com aumento da carga de PTX, principalmente para as cargas mais elevadas de PTX $(1,0 \%$ e 2,0\%). Tal comportamento pode ser atribuído ao fato de a formação das micelas ocorrerem por associação das porções hidrofóbicas da cadeia do polímero para constituir o núcleo de micelas, enquanto as porções hidrofílicas do polímero positivamente carregadas são expostas ao meio aquoso, $i$. e. estes últimos estão predominantemente localizados na superfície das micelas. Contudo, os derivados QCM1 e QCM4 não são copolímeros em bloco, uma vez que a $O$-acilação da quitosana foi realizada em solução de ácido metanossulfônico, favorecendo fortemente a distribuição aleatória de substituintes ao longo das cadeias do polímero, as caracterizações estruturais confirmaram a ocorrência predominante de $O$-substituição. Por consequência, as superfícies das micelas provavelmente também contêm porções hidrofóbicas, assim como uma certa fração de grupos hidrofílicos pode estar localizada nos núcleos das micelas. Portanto, provavelmente devido ao seu baixo teor de substituintes hidrofóbicos, os segmentos hidrofílicos das cadeias QCM1 são predominantemente expostos na superfície das micelas, 
independentemente da carga PTX, e o potencial zeta varia num intervalo estreito. Por outro lado, provavelmente devido ao maior teor de substituintes miristoíla nas cadeias de QCM4, os segmentos hidrofóbicos também estão localizados na superfície das micelas, nos casos das micelas vazias e carregadas com baixas cargas de PTX os valores de potencial zeta são similares.

No entanto, nas micelas QCM4, com carga mais elevada de PTX (1\% e 2\%,) os valores de potencial zeta foram significativamente maiores em comparação com as micelas vazias e as micelas de QMC1, revelando que as micelas mais carregadas tiveram suas porções hidrofílicas mais expostas nas suas superfícies. De fato, tal exposição mais elevada dos segmentos hidrofílicos nas superfícies de micelas de QCM1 com carga de PTX elevada foi acompanhada por uma diminuição significativa do diâmetro médio de micelas em comparação com micelas vazias (Tabela 10), o que foi atribuído às interações mais favoráveis polímero/PTX devido ao maior teor de substituintes miristoíla.

Diante dos resultados obtidos de potencial zeta é possível confirmar que os sistemas micelares preparados a partir dos derivados foram estáveis. Nesse cenário, cabe ressaltar que sistemas formados por nanopartículas são estabilizados por valores maiores que $+30 \mathrm{mV}$, indicando maior estabilidade física (PREZOTTI, 2017).

Adicionalmente, sistemas nanoestruturados com carga superficial positiva são facilmente transportadas através do muco, pela interação eletrostática com as cargas negativas presentes na mucina, e por consequência, essa interação auxilia na absorção das partículas através do muco e aumenta a internalização pelas células epiteliais, que também são carregadas negativamente (ROGER et al., 2010; TAVARES, 2013). Portanto, os resultados obtidos de potencial zeta mais uma vez reforçam que é promissor o uso do derivado para desenvolvimento de sistemas para encapsulação de fármacos para aplicação via administração oral. 


\subsubsection{Microscopia Eletrônica de Transmissão (MET)}

A análise de microscopia eletrônica de transmissão foi realizada com intuito de corroborar com os resultados obtidos por DLS. As imagens da amostra QCM1 correspondem às Figura 26 a e b, sendo as Figuras 20 c e d referentes a amostra QCM4. De acordo com as imagens de MET foi possível observar que as micelas apresentaram formas esféricas e tamanhos de aproximadamente 380 a 400nm, enquanto que a partir da técnica de DLS as mesmas apresentaram tamanhos de aproximadamente $481 \mathrm{~nm}$, lembrando que a técnica de DLS obtém uma média ponderada de valores de tamanho.

Figura 26: Imagens de MET da amostra QCM1 (a e b) e QMC4* (c e d) carregadas com 2\%, com escala correspondente a (a e c) $100 \mathrm{~nm}$ e (b e d) $200 \mathrm{~nm}$, respectivamente.

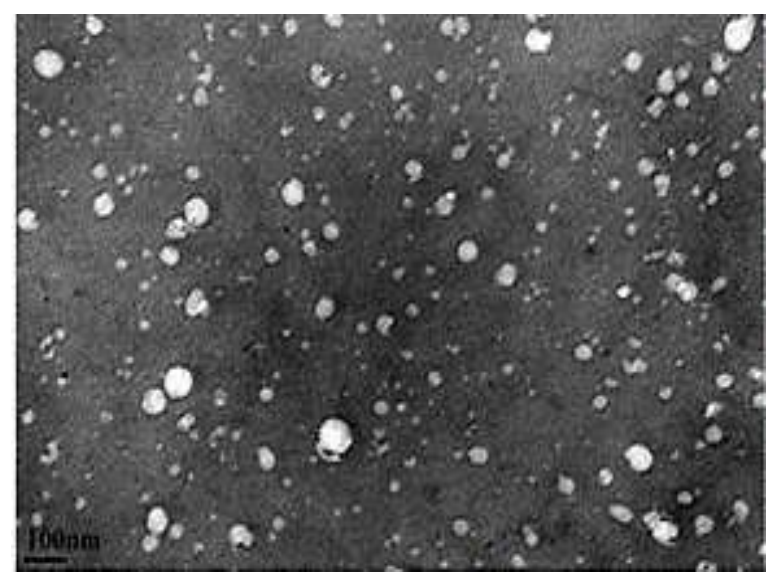

(a)

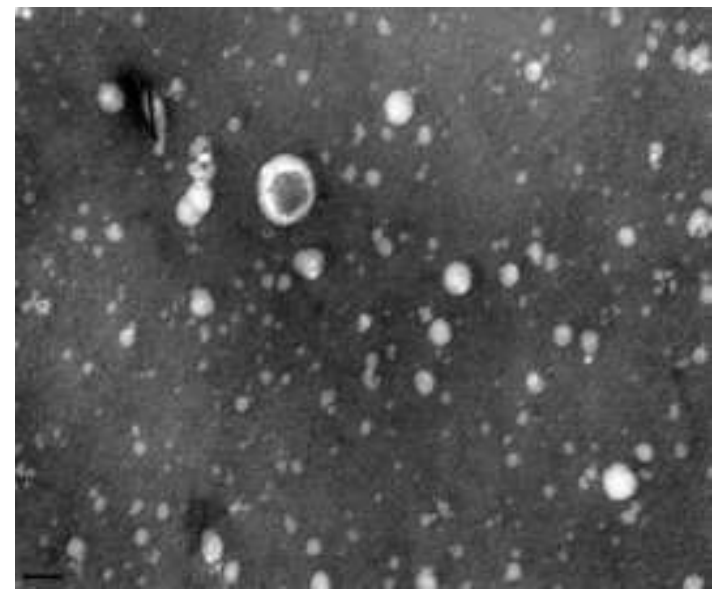

(c)

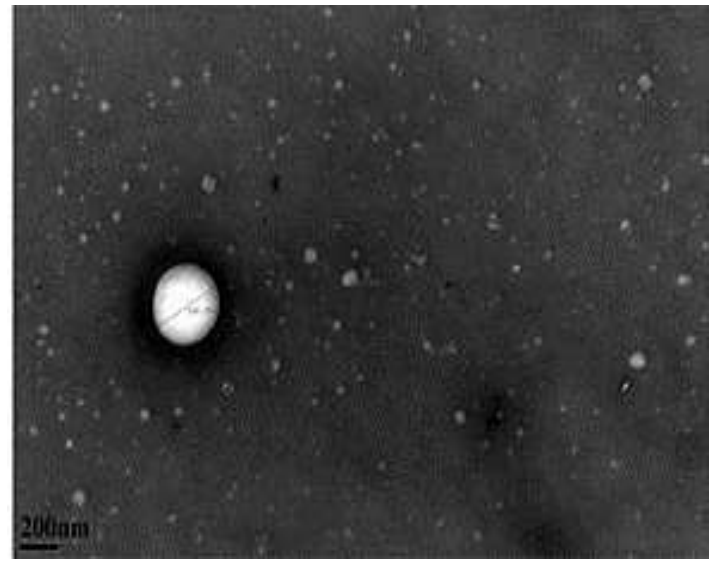

(b)

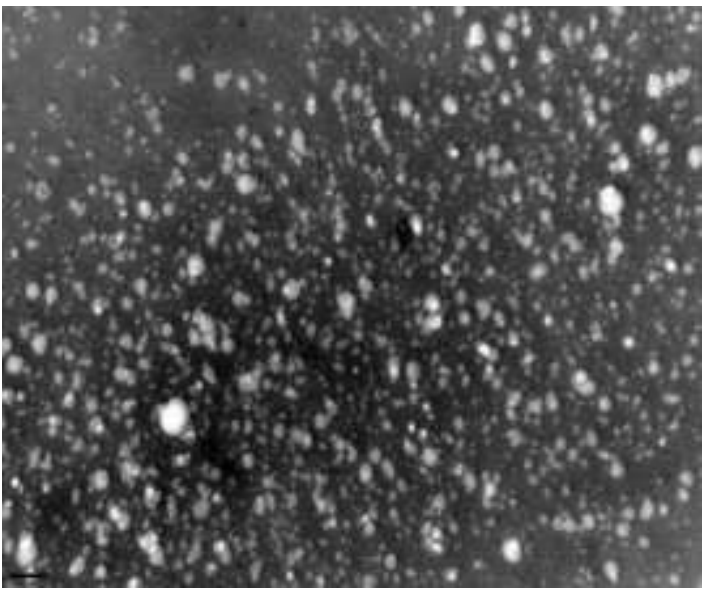

(d) 


\subsubsection{Avaliação da citotoxicidade}

Os ensaios de citotoxicidade são amplamente utilizados em estudos de toxicologia in vitro e dentre os ensaios mais comuns estão os ensaios de LDH (ensaio de proteína) e MTT (sal de tetrazólio), que são utilizados para detecção de citotoxicidade ou viabilidade celular após a exposição a substâncias possivelmente tóxicas (FOTAKIS; TIMBRELL, 2006).

No entanto, desde os ensaios realizados por Monsmann em 1983, os ensaios de citotoxicidade via MTT receberam destaque, devido à facilidade de manipulação, rápida detecção dos resultados e capacidade de ser aplicado em diferentes linhagens celulares (MOSMANN, 1983). O reagente MTT ([brometo de 3- [4,5-dimetiltiazol-2-il] -2,5-difeniltetrazólio]), é um sal de tetrazólio solúvel em água, capaz de ser convertido em formazan a partir da clivagem realizada pelas mitocôndrias. Nos ensaios de citotoxicidade o formazan (sal roxo insolúvel em água) se acumula sobre as células sadias, devido à sua impermeabilidade nas membranas celulares, sendo então facilmente detectável a partir de análises de espectroscopia na região do visível (BELLAMY, 1992).

Mediante ao exposto, a avaliação da citotoxicidade das micelas vazias, carregadas e do fármaco livre foram realizadas via ensaio de MTT e os resultados foram interpretados segundo a ISO 10993-5 (ISO/EN10993-5, 2009), a qual estabelece que determinada substância deve ser considerada tóxica se resultar em viabilidade celular inferior a $70 \%$.

De acordo com os resultados já apresentados acima, o derivado escolhido para desenvolver os ensaios biológicos foi o QCM1, uma vez que as micelas de QCM1 apresentaram proporção polímero/fármaco de 100/2 (m/m), que dentre as micelas de QCM1 foi a que encapsulou maior quantidade de PTX $(100 \mu \mathrm{g})$. A escolha desta formulação teve como objetivo principal encapsular e solubilizar o fármaco hidrofóbico, mas a escolha também foi baseada no 
baixo grau de substituição do derivado QCM1, para assim evitar a exposição dos segmentos hidrofóbicos na superfície das micelas.

Com intuito de avaliar a segurança intestinal e a biocompatibilidade do polímero QCM1, foram empregadas micelas vazias (QCM1), micelas carregadas com PTX (QCM1-PTX) e o fármaco livre (PTX) para realizar os ensaios in vitro com células intestinais Caco-2 e HT29-MTX. As amostras foram incubadas durante 24 horas e a viabilidade celular foi avaliada.

A viabilidade celular nos diferentes modelos de células tratadas com QCM1, QCM1PTX e PTX nas concentrações de 0,01 a $100 \mu \mathrm{g} / \mathrm{mL}$ são ilustradas na Figura 27 para linha celular Caco-2 e na Figura 28 para HT29-MTX. Foi observado que para maior concentração das amostras $(100 \mu \mathrm{g} / \mathrm{mL})$, as células intestinais do modelo Caco-2 apresentaram viabilidade significativamente maior na presença das micelas QCM1-PTX em comparação com aquelas incubadas na presença de PTX livre. Claramente, os resultados mostraram que as micelas QCM1 e QCM1-PTX apresentaram menor toxicidade (viabilidade celular $\geq 70 \%$ ) em comparação com a PTX livre (viabilidade celular $\leq 50 \%$ ), o que foi consistente com resultados da literatura usando diferentes derivados de quitosana para encapsulação de PTX (MO et al., 2011; PAN et al., 2013; ALMEIDA et al., 2017). Consequentemente, foi concluído que a encapsulação de PTX em micelas QCM1 reduziu a toxicidade do fármaco. 
Figura 27: Viabilidade celular de QCM1, QCM1- PTX e PTX livre, contra a linha celular Caco-2 nas concentrações de 0,001-100 $\mu \mathrm{g} / \mathrm{mL}$ após incubação durante $24 \mathrm{~h}$. Os valores foram relatados como média $\pm \mathrm{DP}$ $(\mathrm{n}=3)$. $(* *)$ e $(* * *)$ denota uma diferença significativa $(\mathrm{p}<0,01$ e $\mathrm{p}<0,001)$.

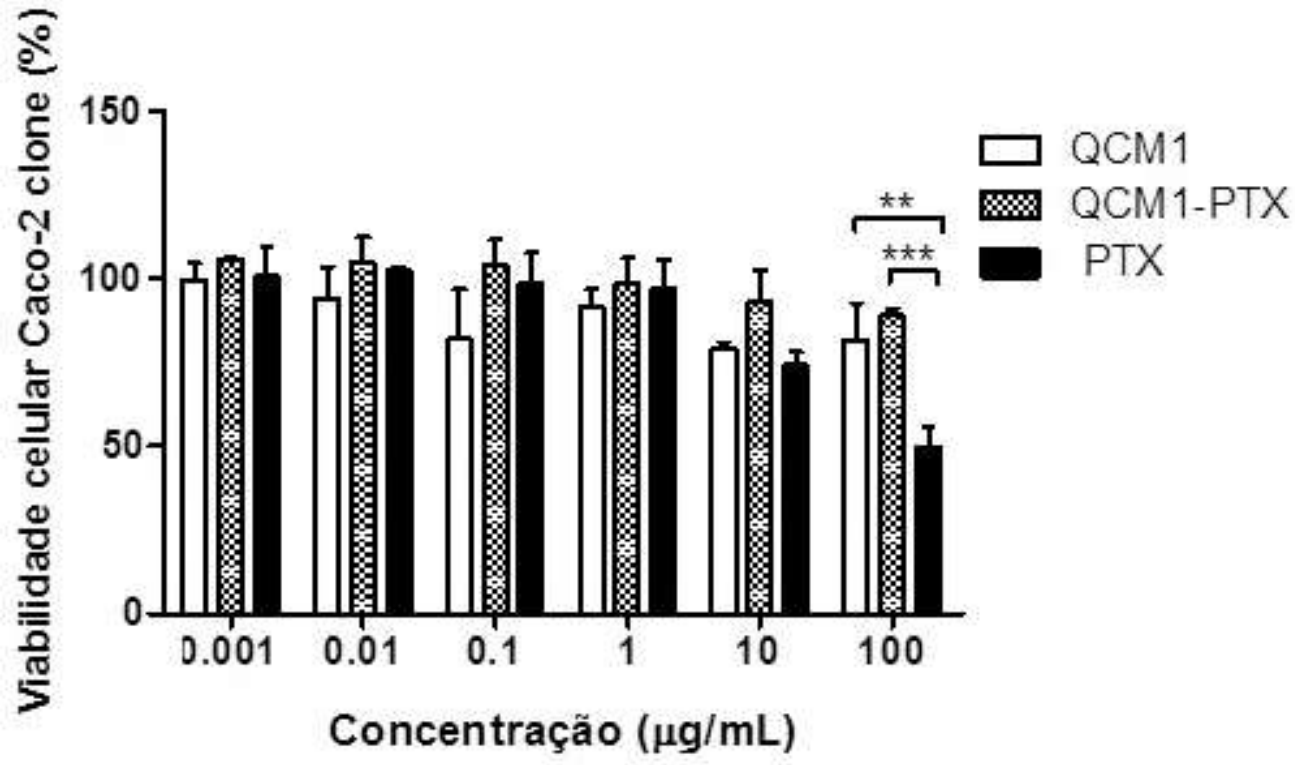

Figura 28: A viabilidade celular de QCM1, QCM1- PTX e PTX livre, contra a linha celular HT29MTX nas concentrações de 0,001-100 $\mu \mathrm{g} / \mathrm{mL}$ após incubação durante 24 horas. Os valores foram relatados como média \pm DP $(\mathrm{n}=3)$. $(* *)$ e $(* * *)$ denota uma diferença significativa.

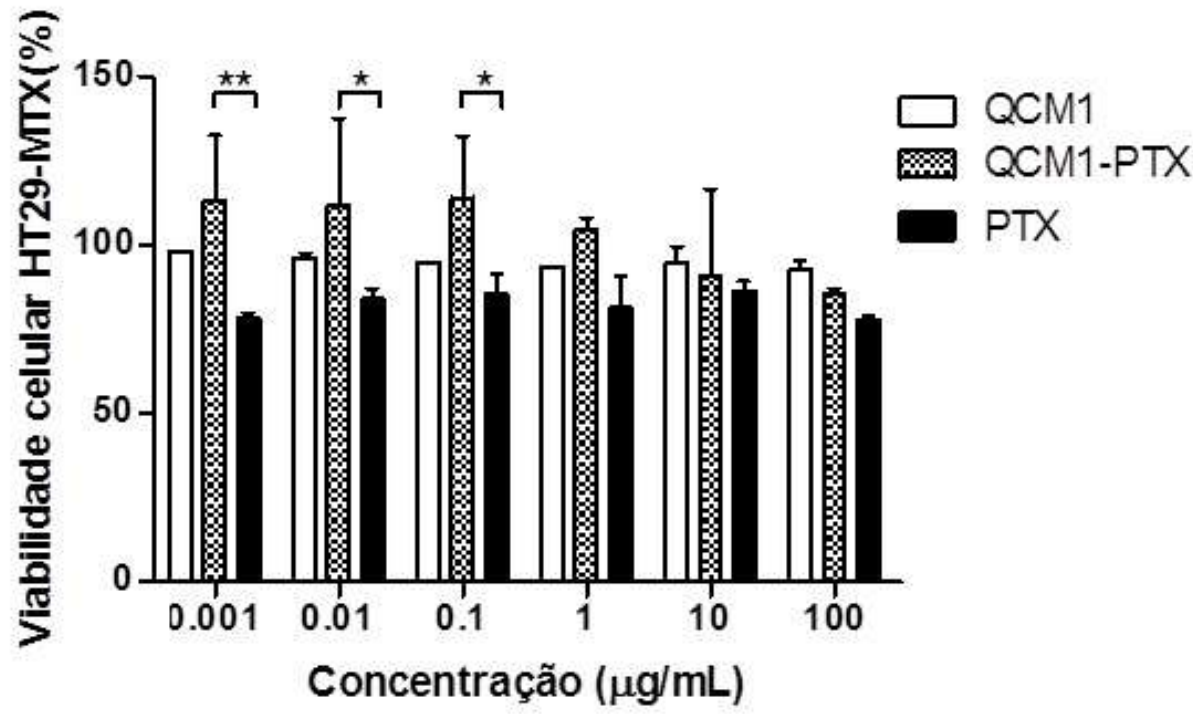

As células HT29-MTX apresentaram alta viabilidade na presença de micelas QCM1e QCM1-PTX, apresentando esta última menor toxicidade em comparação com o PTX livre (Figura 28) comprovando que a encapsulação é vantajosa. 
De fato, estes resultados podem ser tomados como prova de conceito, no sentido em que a encapsulação de PTX em micelas QCM1 é segura para administração oral. No entanto, é importante destacar que este ensaio não foi realizado para avaliar a eficácia antitumoral do PTX, mas para avaliar a segurança dos materiais na presença de células intestinais. Assim, foi concluído que para ambas as linhas celulares, i. e. as células Caco-2 e HT29-MTX, sistemas micelares à base de QCM1 não apresentaram toxicidade, sendo seguros para serem utilizados na liberação de PTX.

\subsubsection{Avaliação da permeabilidade in vitro em monocultura de células Caco-2 e co-cultura (Caco-2/HT29-MTX)}

Modelos celulares a partir de células Caco-2 são estudados desde 1980, e o objetivo destes estudos tem sido avaliar as funções intestinais que essas células exercem. A capacidade de diferenciação espontânea em cultivos in vitro e as características morfológicas e bioquímicas encontradas no intestino delgado humano, são bem representados a partir do modelo de cultura celular do tipo Caco-2. (INGELS et al., 2004; LIND et al., 2007).

Nesse tipo de ensaio, quando as células Caco-2 são mantidas em condições adequadas de cultivo, elas são capazes de crescer e formar uma monocamada de células cilíndricas polarizadas, apresentando microvilosidades na borda apical do transwell, junções oclusivas entre as células adjacentes, enzimas hidrolisantes e sistemas de transporte mediados por portadores de açúcares, aminoácidos e diversos fármacos (INGELS et al., 2002; FOSSATI et al., 2008).

Os estudos de permeabilidade com essa linhagem celular tem sido constantemente usados para avaliar o efeito de diferentes sistemas frente as junções epiteliais, por meio de medidas de resistência elétrica transepitelial (TEER) (ANTUNES et al., 2013). No entanto, apesar das células Caco-2 serem comumente usadas, esse modelo apresenta ausência de propriedades importantes, necessitando então de um refinamento adicional (PONTIER et al., 2001). Sendo assim, conforme os resultados apresentados a seguir, foram aplicados 2 modelos celulares diferentes, um contendo 
apenas células Caco-2 (modelo de monocultura) e modelo de co-cultura (Caco-2/ HT29-MTX). O segundo modelo foi escolhido devido à sua capacidade de melhor mimetizar o intestino, apresentando células absorventes (Caco-2) (Figura 30 a) e células produtoras de muco (HT29MTX) (Figura 30 b) (ANTUNES et al., 2013; ARAÚJO; SARMENTO, 2013).

Para realização do ensaio de permeabilidade, inserts foram usados como suportes para formação das monocamadas celulares, tanto para os modelos de monocultura quanto para os de cocultura, conforme é representado na Figura 29, onde as células foram cultivadas por 21 dias.

Figura 29: Esquema representativo do crescimento de monocamadas dos modelos celulares usados nos estudos de permeabilidade.

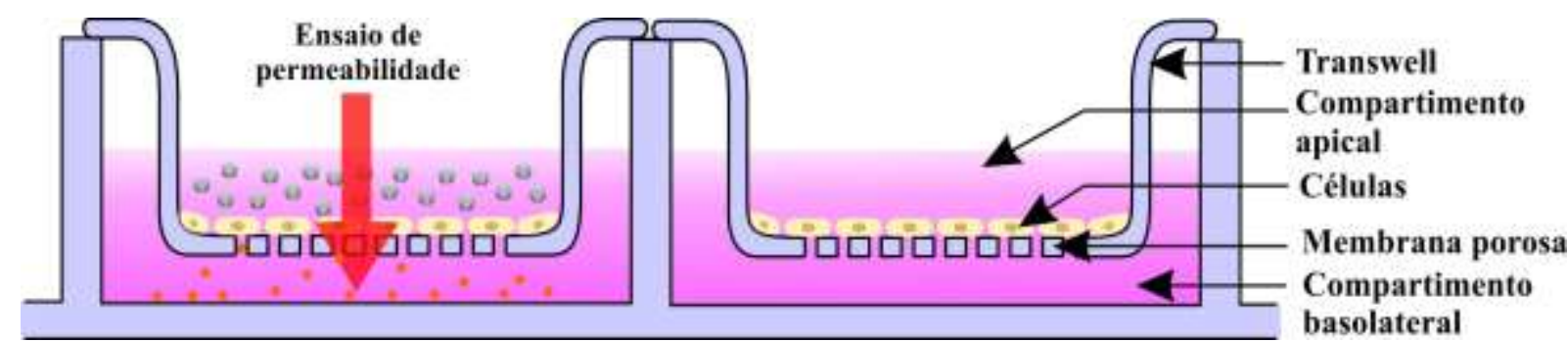

Fonte: Autoria própria.

O cultivo das diferentes linhagens em frascos T75 são apresentadas nas Figura 30 a e b, sendo que estas imagens são referentes às células Caco-2 e HT29-MTX. As imagens apresentadas nas Figura 30 b e c mostram o desenvolvimento da monocamada das células Caco-2 para o modelo de monocultura no início (3 dias) e no fim do cultivo (21 dias), o mesmo é apresentado nas Figura 30 d e e, porém, para o modelo de co-cultura com células Caco-2 /HT29-MTX. As Figura 30 g e h mostram o insert apenas com meio de cultura, sendo que este refere-se ao branco insert sem células).

Figura 30: Imagens de acompanhamento do crescimento e formação das monocamadas celulares: (a) células Caco2 crescendo em frasco T75; (b) células HT29-MTX em frasco T75; (c) terceiro dia do crescimento da monocamada do modelo de monocultura (Caco-2); (d) vigésimo primeiro dia de crescimento da monocamada da monocultura; 
(e) quarto dia de crescimento do modelo de co-cultura (Caco-2/HT29-MTX); (f) vigésimo primeiro dia de crescimento da monocamada da co-cultura; (g) branco no segundo dia e (h) branco no vigésimo primeiro dia.

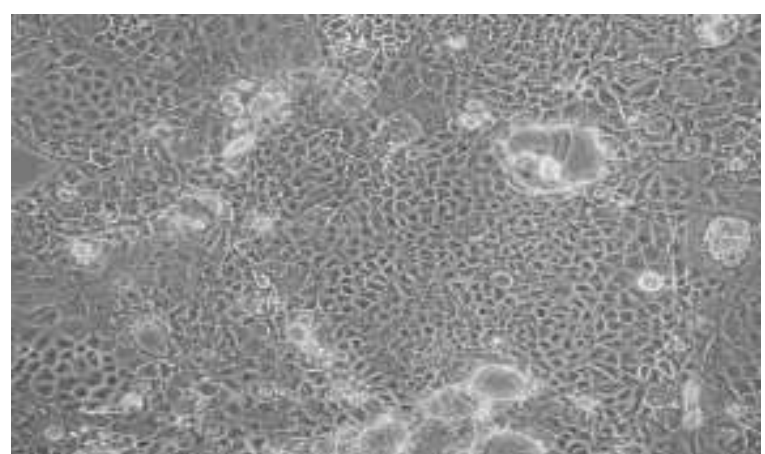

Caco-2 (a)

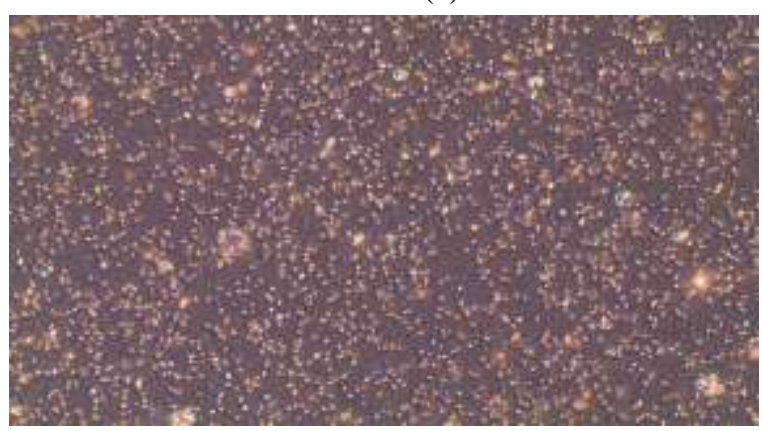

Caco $2-3^{\circ}$ dia (c)

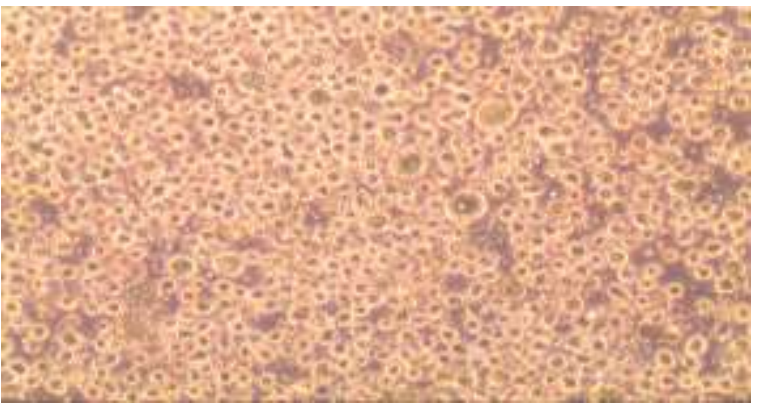

Caco-2 /HT29-MTX - $4^{\circ}$ dia (e)

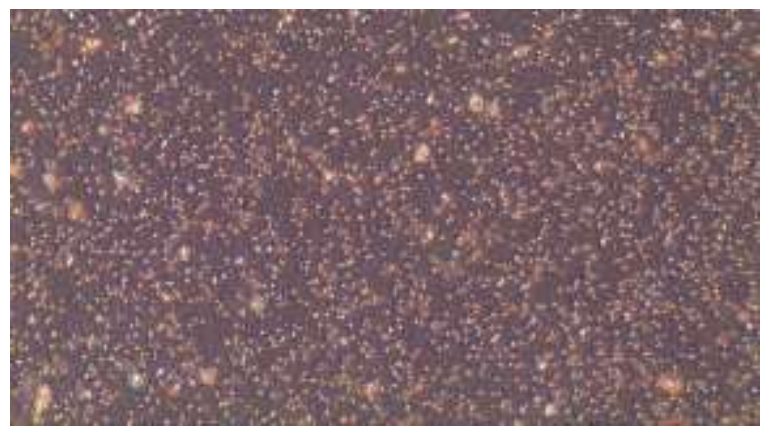

Branco $-2^{\circ}$ dia $(\mathrm{g})$

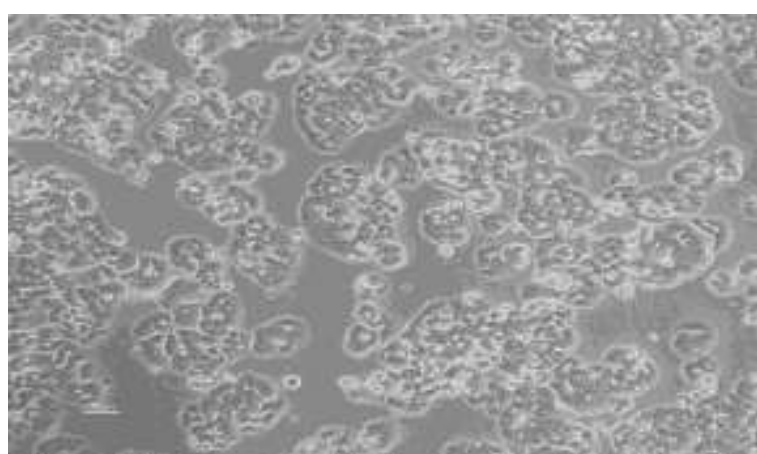

HT29-MTX (b)

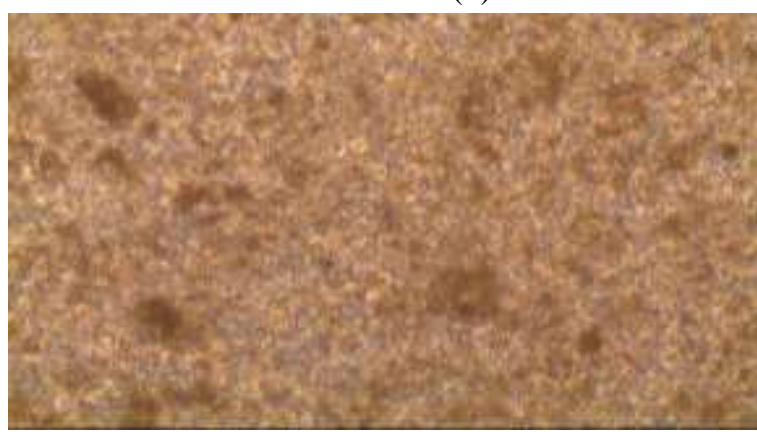

Caco $-2-21^{\circ}$ dia $(d)$

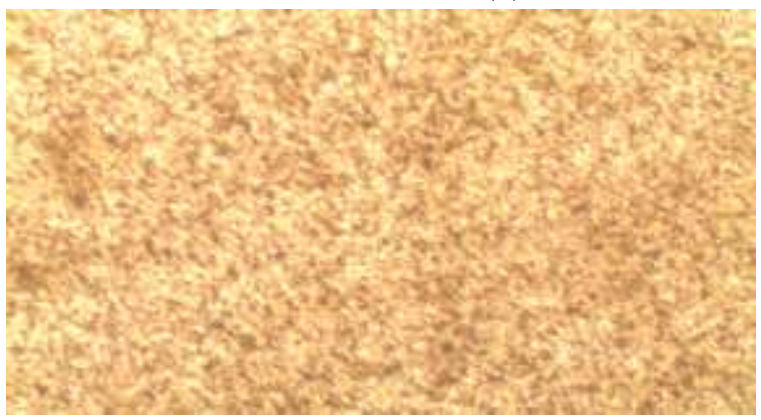

Caco-2 /HT29-MTX - $21^{\circ}$ dia (f)

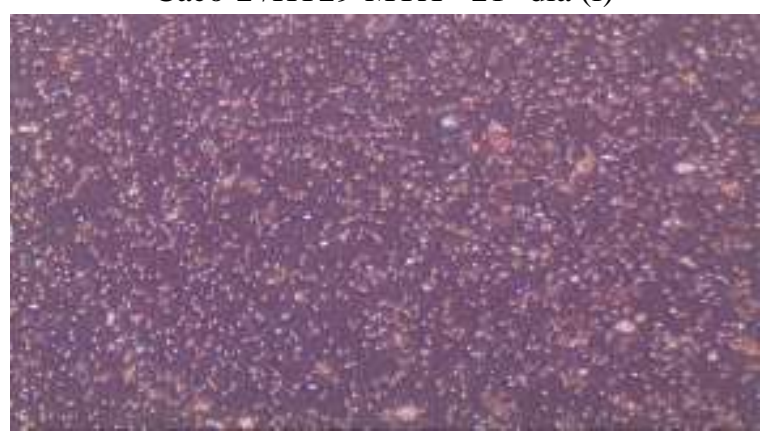

Branco $-21^{\circ}$ dia $(\mathrm{h})$

Durante os 21 dias de formação da monocamada em cada insert, a resistência elétrica transepitelial (TEER) foi medida em diferentes dias. Por se tratar de modelos que se assemelham 
ao epitélio intestinal humano, esse tipo de medida pode ser realizada devido a diferentes forças existentes entre os diferentes tipos de células, e a tensão pode ser medida através do TEER.

A medida do TER foi realizada em diferentes dias e os valores são apresentados nas Figura 31 para o modelo de monocultura e Figura 32 para a co-cultura, onde mostram a integridade epitelial das monocamadas, que aumentam à medida que a monocamada cresce ao longo dos dias. De acordo com a literatura, os valores de TEER são aceitáveis no intervalo 150 - $1600 \Omega . \mathrm{cm}^{2}$, o que indica que a monocamada pode ser utilizada nos experimentos de permeabilidade (X; ARBOR, 1996; PONTIER et al., 2001; SHAH et al., 2006). Conforme observado na Figura 31, o TEER do modelo de monocultura apresentou valores de aproximadamente $1000 \Omega . \mathrm{cm}^{2}$ e na Figura 32 foi observado valores de $200 \Omega . \mathrm{cm}^{2}$ após 21 dias, mostrando que os resultados estão de acordo com os valores indicados na literatura.

Figura 31: Gráfico dos valores de TEER em função do tempo, medido durante os 21 dias de formação da monocamada para o modelo de monocultura (células Caco-2).

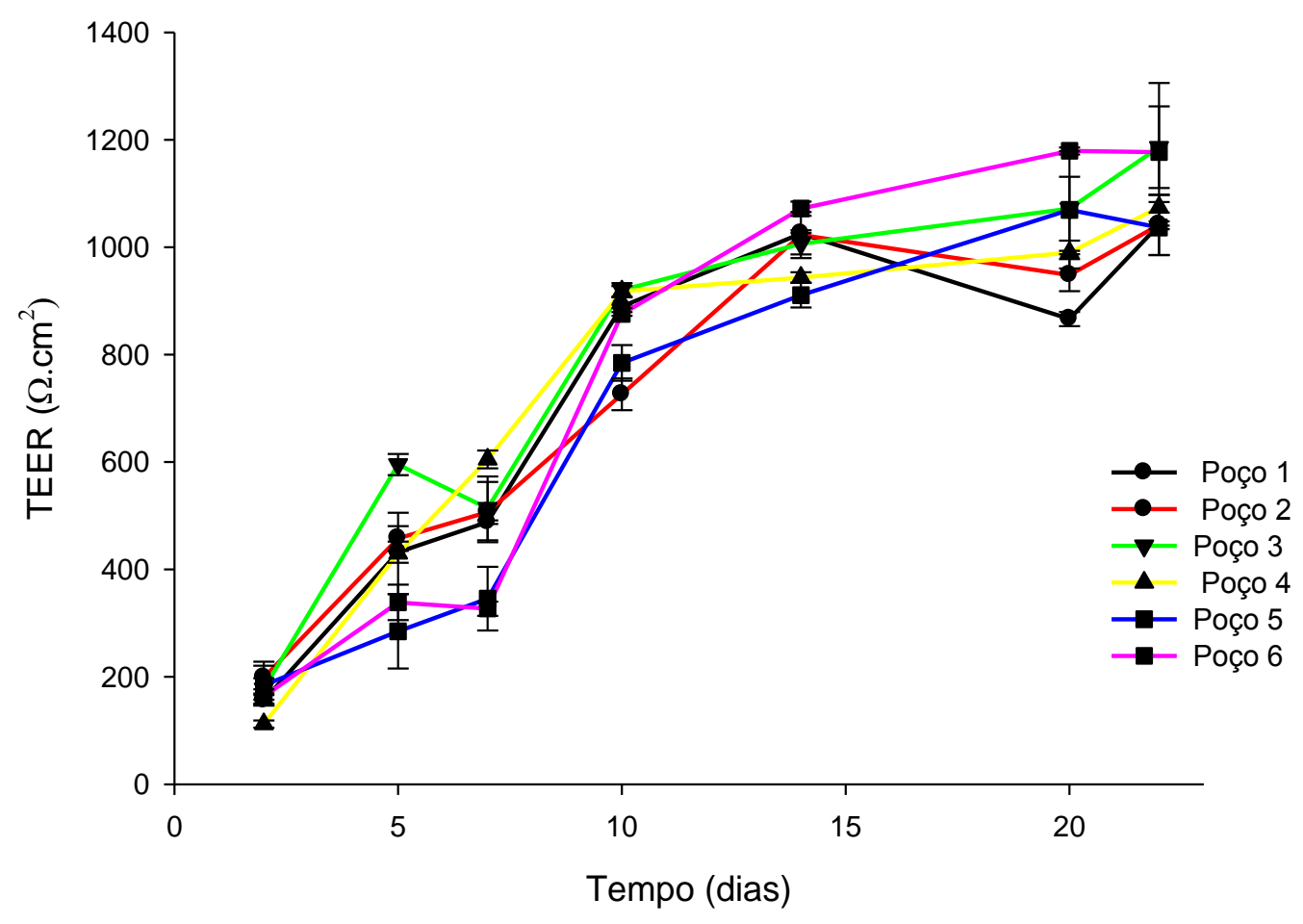


Figura 32: Gráfico dos valores de TEER em função do tempo, medido durante os 21 dias de formação da monocamada para o modelo de co-cultura (células Caco-2 / HT29-MTX).

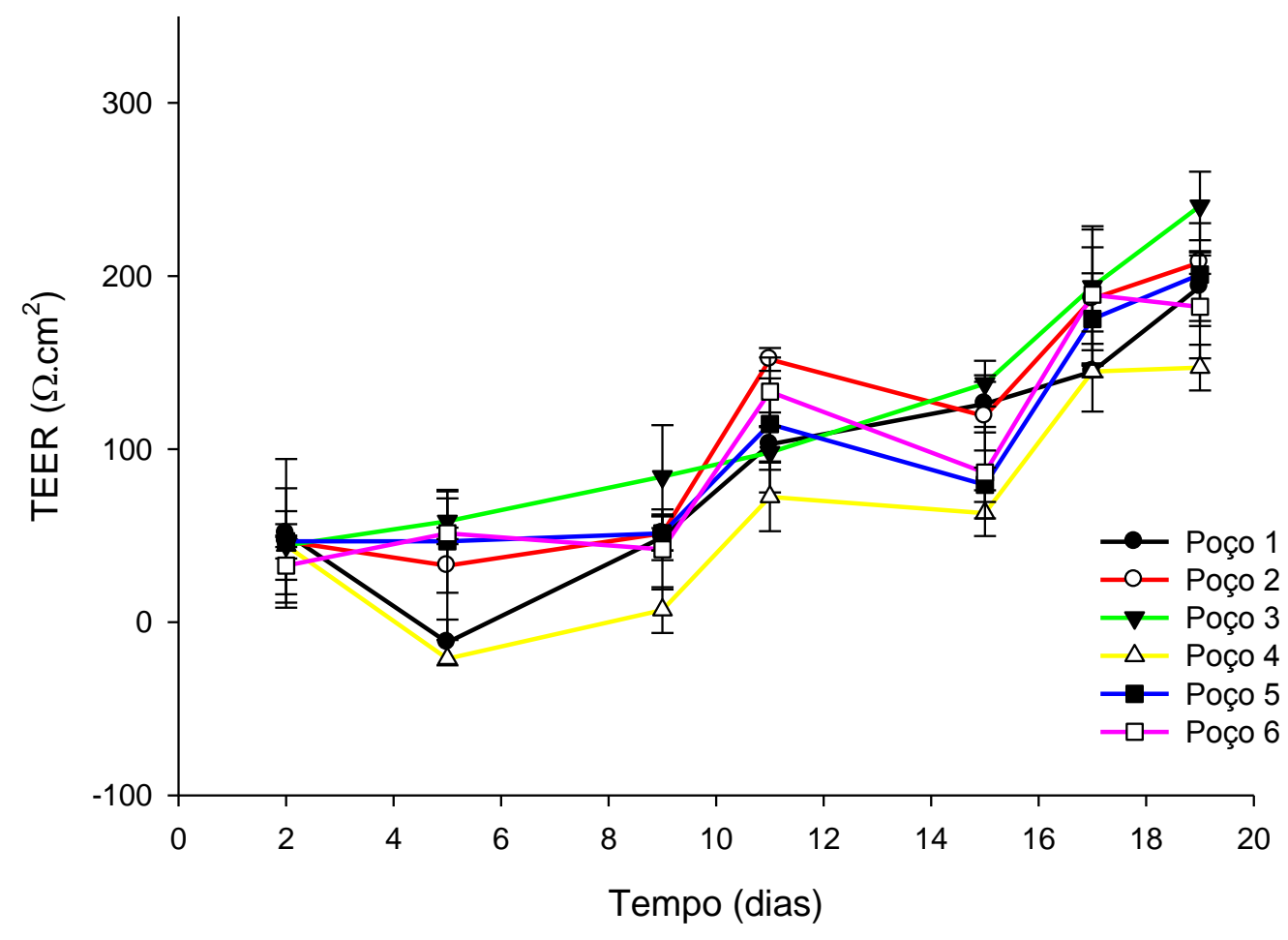

Segundo os resultados obtidos, também foi possível observar que o modelo de co-cultura apresentou valores de TEER inferiores aos da monocultura, sendo que esse comportamento é explicado devido à presença das células HT29-MTX (secretoras de muco), que modulam a geometria das junções do estreito epitelial, fazendo que tenham uma abertura maior comparada ao modelo de monocultura (WIKMAN et al., 1993; HILGENDORF et al., 2000; CHEN; ELISIA; KITTS, 2010; CALATAYUD et al., 2012; ROCHA; VÉLEZ; DEVESA, 2012).

Ao fim dos 21 dias o ensaio de permeabilidade foi realizado com o objetivo de avaliar o efeito do derivado 3,6-O, $O^{\prime}$-dimyristoil quitosana sobre a permeabilidade de PTX in vitro.

A quantidade acumulativa de PTX permeado foi traçada como uma função do tempo conforme mostrado na Figura 33. Para ambos os modelos, nos primeiros 90 minutos o PTX que permeou através das monocamadas de células apresentou perfil semelhante. Após 90 min, o modelo Caco-2 mostrou um aumento na permeabilidade do fármaco, atingindo uma massa cumulativa de 
PTX de $0,50 \mu \mathrm{g}$ e no final do teste, permeou-se $1,0 \mu \mathrm{g}$ de PTX através da monocamada. Para o modelo de co-cultura, a quantidade de PTX permeada após 90 min foi de $0,44 \mu \mathrm{g}$ e no final do teste $0,49 \mu \mathrm{g}$ permearam a monocamada.

Comparando a permeabilidade do PTX, verificou-se que era 2 vezes maior quando carregado por QCM1 em comparação com fármaco livre, o que está de acordo com os resultados obtidos por. Mo et al (2011), que obtiveram valores de permeabilidade aparente para o PTX encapsulado em micelas de quitosana de 8,55 $\pm 0,90 \times 10^{-6} \mathrm{~cm} \mathrm{~s}^{-1}$, resultando em uma permeabilidade 2 vezes melhor em comparação com PTX livre (MO et al., 2011).

De acordo com os dados obtidos, os valores de TEER refletiram a integridade da monocamada, e a diminuição nos valores de TEER foi consequência da abertura das junções estreitas de células. Conforme apresentado na Figura 33, para ambos os modelos não foram observadas alterações significativas dos valores de TEER durante os testes de permeabilidade, o que está de acordo com os resultados esperados para o ensaio de permeabilidade.

Com base nos resultados de permeabilidade de PTX, sugere-se que estas micelas de derivados de quitosana apresentam propriedades mucoadesivas importantes que podem melhorar a interação da PTX com as células, colocando o fármaco anticancerígeno em contato com as células cancerígenas, o que pode ser eficaz para tratamento de câncer. 
Figura 33: Perfil de permeabilidade cumulativa in vitro de micelas carregadas com PTX através dos modelos de monocultura Caco-2 e co-cultura Caco-2 / HT29-MTX. Todos os experimentos foram conduzidos do compartimento apical ao basolateral em HBSS a $37^{\circ} \mathrm{C}$. As barras de erro representam a média \pm DP $(\boldsymbol{n}=3)$.
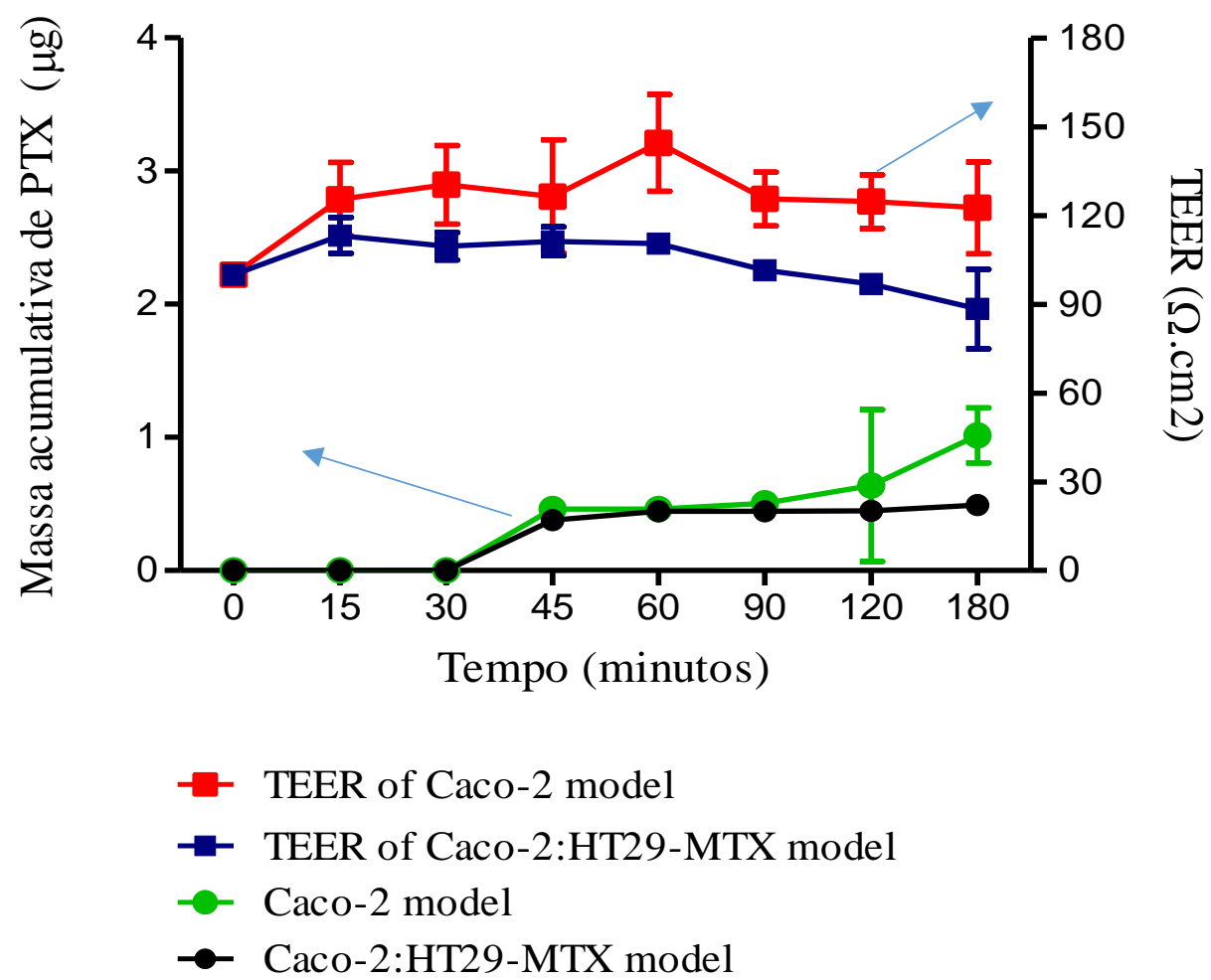

\subsubsection{Liberação in vitro do fármaco}

Para avaliação do perfil de liberação do fármaco a partir das micelas do derivado QCM1, a formulação (QCM1-PTX) foi submetida a diferentes meios de dissolução, sendo esses capazes de simular os fluídos biológicos com valores de pH iguais a 1,2 e 6,8, referentes ao fluido gástrico simulado sem enzimas (FGSE) e fluido intestinal simulado sem enzimas (FISE), respectivamente. Nesse ensaio o método utilizado foi o de diálise, sendo que alíquotas foram coletadas em diferentes intervalos de tempo por um período de $48 \mathrm{~h}$.

Os resultados obtidos no ensaio de liberação são apresentados na Figura 34, e a partir destes foi possível observar perfis de liberação semelhantes para ambos os sistemas de simulação de fluidos biológicos, resultando na liberação de 9\% e 13\% de PTX em FGSE e em FISE, respectivamente. 
Figura 34: O perfil de liberação de PTX após incubação em fluido gástrico simulado (FGSE) pH=1,2 e fluido intestinal simulado (FISE) $\mathrm{pH}=6,8$, todos sem a presença de enzimas, mantidos sob condições de lavagem a $37^{\circ} \mathrm{C}$. Dados expressos como média SD, $\boldsymbol{n}=3$.

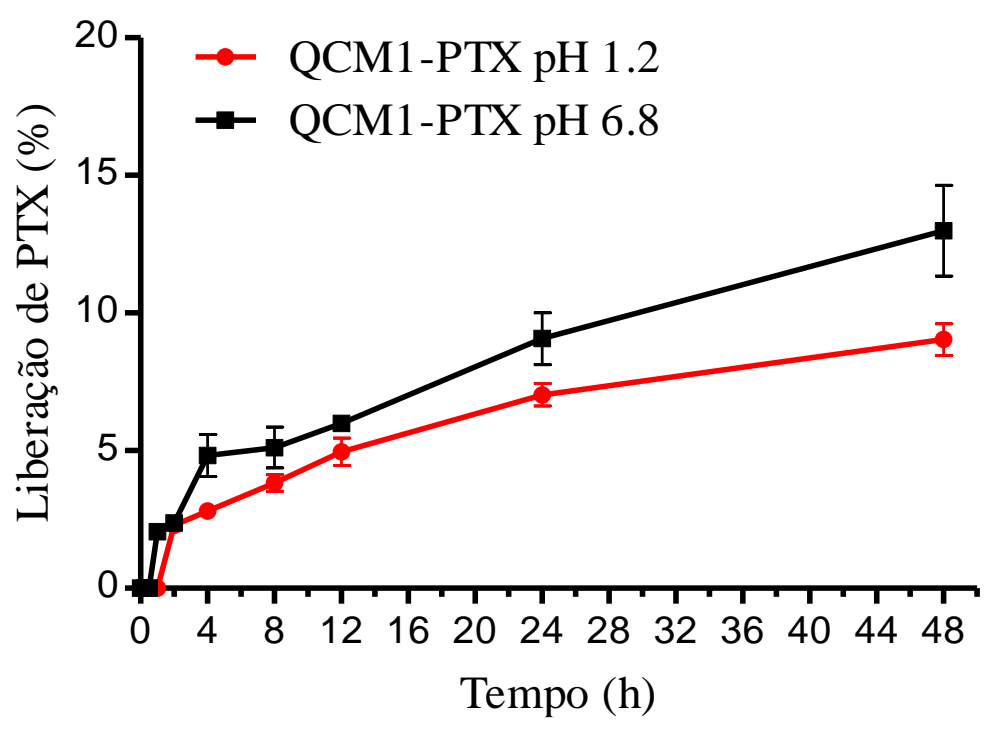

Segundo os resultados obtidos na literatura, o método de encapsulação tem consequências sobre a distribuição do princípio ativo na matriz carreadora, sendo então um fator determinante sobre o perfil de liberação. Encapsulações em que a adição do fármaco ocorre após a formação das partículas, o fármaco é encontrado adsorvido à superfície, obtendo um perfil de liberação rápido, que é controlado pelos mecanismos de dessorção e difusão do fármaco. Por outro lado, quando o contrário ocorre, o fármaco é adicionado durante um processo de polimerização e/ou micelização, o mesmo permanece encapsulado no interior do sistema, resultando em liberação do tipo sustentada. Portanto, nesse caso a liberação do fármaco se dá através da degradação do carreador ou por meio de difusão através da parede polimérica (CHAUVIERRE et al., 2007; PARK et al., 2010; BERNKOP-SCHNÜRCH; DÜNNHAUPT, 2012; TAVARES, 2013).

Adicionalmente, segundo dados da literatura, sistemas de administração oral à base de quitosana para absorção intestinal tem sido amplamente usados, devido a capacidade que apresentam de proteger os agentes terapêuticos das condições hostis do trato gastrointestinal, sendo assim capazes de aprisionar e liberar os agentes especificamente no cólon, e só então 
liberar através da degradação das ligações glicosídicas da quitosana pela microflora presente no cólon (TOZAKI et al., 1997; HEJAZI; AMIJI, 2003; PARK et al., 2010).

Devido ao ensaio de liberação ser realizado em fluídos biológicos simulados sem a presença das enzimas contidas no estômago e intestino, e ao fato das micelas serem resistentes as diferenças de $\mathrm{pH}$ aplicadas, a baixa porcentagem de liberação pode ser justificada, sendo que o fármaco só seria completamente liberado na presença de enzimas capazes de degradar o polímero. Por fim, levando em consideração os resultados obtidos e as características do polímero usado na encapsulação do PTX, pode-se concluir que para esse sistema micelar o perfil de liberação foi do tipo sustentada.

\subsubsection{Conclusão}

Os resultados obtidos mostraram que foi possível obter micelas formadas a partir dos derivados 3,6-O,O'- dimiristoilquitosana. Ambas as amostras, QCM1 e QCM4, apresentaram comportamento de auto-associação e permitiram o eficiente encapsulamento de paclitaxel (PTX). As micelas exibiram dimensões nanométricas no intervalo de $280 \mathrm{~nm}-500 \mathrm{~nm}$ com potencial zeta positivo $(>+30 \mathrm{mV})$. Os ensaios de citotoxicidade das amostras QCM1 e QCM1-PTX e PTX mostram que o sistema micelar desenvolvido não apresenta toxicidade em relação às células do sistema colón retal Caco-2 e HT29-MTX, na gama de concentração testada, uma vez que ambas as linhas de células apresentaram alta viabilidade em comparação àquelas expostas ao PTX não encapsulado. Os resultados de permeabilidade refletem que as micelas de QCM1 são potencialmente interessantes para administração oral de fármacos pouco solúveis em água, assim como o ensaio de liberação mostrou que o PTX pode ser liberado, ainda que a liberação completa só venha se dar na presença de enzimas que são capazes de degradar o polímero, no entanto, sua liberação mostrou que pode ser sustentada para além de $48 \mathrm{~h}$. Estes resultados sugerem que micelas à base do derivado QCM1 são potenciais promissores transportadores de PTX ou outros fármacos hidrofóbicos. 


\subsection{Parte 3: Estudos de encapsulação e liberação de camptotecina (CPT)}

Nessa etapa do trabalho o polímero selecionado para os estudos de eficiência de encapsulação e liberação da camptotecina foi o derivado QCM1. A escolha deste derivado foi realizada a partir dos excelentes resultados obtidos na encapsulação de PTX, que pouco se diferenciou pelo uso do derivado de menor e o de maior grau de substituição. Em vista das semelhanças dos estudos realizados com PTX e com CPT, e devido ao fato que os detalhes experimentais e teóricos já terem sido descritos no capítulo anterior, alguns dados e resultados serão abordados de forma mais direta neste capítulo.

\subsubsection{Eficiência de Encapsulação}

Para obtenção dos valores de eficiência de encapsulação a partir da análise de espectroscopia de ultravioleta, foi realizada a validação da metodologia com intuito de demostrar que o procedimento analítico empregado para quantificar o fármaco é apropriado e permite quantificar de forma seletiva a camptotecina (CPT).

Assim como no caso das micelas carregadas com PTX, a quantificação da CPT encapsulada foi realizada através do método indireto, sendo que o fármaco não encapsulado se encontra no sobrenadante, fase separada a partir da centrifugação com uso de filtros Amicon.

\subsubsection{Validação segundo a ANVISA}

Conforme a Resolução 899/9, a validação de um método deve ser realizada através da determinação dos parâmetros de especificidade, linearidade, precisão, exatidão e limite de detecção e quantificação (BRASIL, 2003).

Adicionalmente, sabe-se que métodos espectrofotométricos permitem a determinação quantitativa de fármacos através da absorção nas regiões ultravioleta, visível e infravermelho. 
Portando, tais técnicas são amplamente empregadas em análises quantitativas, por apresentarem fácil execução, boa sensibilidade, exatidão, seletividade moderada e custo reduzido (PREZOTTI, 2017). Levando em consideração o que foi descrito acima, a técnica de espectroscopia de UV foi utilizada no estudo de validação do método de quantificação do fármaco CPT.

\subsubsection{Máxima absorção de CPT}

Para iniciar a validação da técnica, uma varredura espectral da amostra de CPT foi realizada, afim de obter o pico de máxima absorção da amostra. A partir da curva de absorção do fármaco foi determinado o comprimento de onda máxima de CPT na região do ultravioleta, conforme é apresentado na Figura 35, onde foi observado um pico de máxima absorção em 370 nm.

Figura 35: Gráfico do espectro de absorção na região do UV para o CPT solúvel em DMSO.

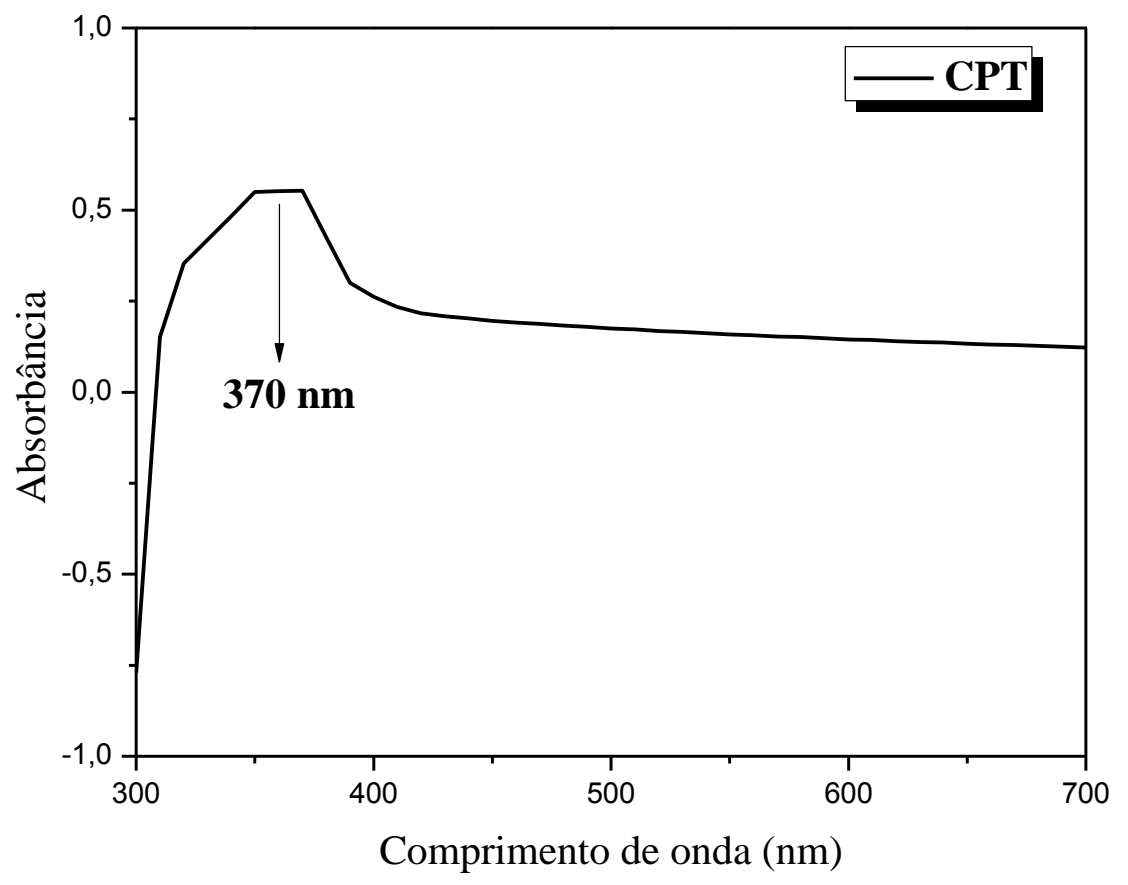




\subsubsection{Especificidade/ seletividade}

A capacidade do método distinguir a substância analisada de todas as outras presentes na amostra é conhecida como especificidade (CAUSON, 1997). Na avaliação da especificidade / seletividade através de um método não cromatográfico como no caso da espectroscopia de UV, o método só pode ser empregado na quantificação do fármaco quando a análise se enquadra com resultados de seletividade aceitáveis.

Sendo assim o perfil espectral do polímero usado na formulação das micelas foi avaliado conforme é apresentado na Figura 36, e de acordo com os dados obtidos foi observada a ausência de picos de absorção em $370 \mathrm{~nm}$, pico de máxima absorção de CPT, assim confirmando que o método usado apresentou seletividade e especificidade frente ao fármaco estudado.

Figura 36: Gráfico do espectro de absorção na região do UV para o polímero QCM1 solúvel em ácido acético $0,1 \mathrm{M}$ e espectro do fármaco CPT em menor escala.

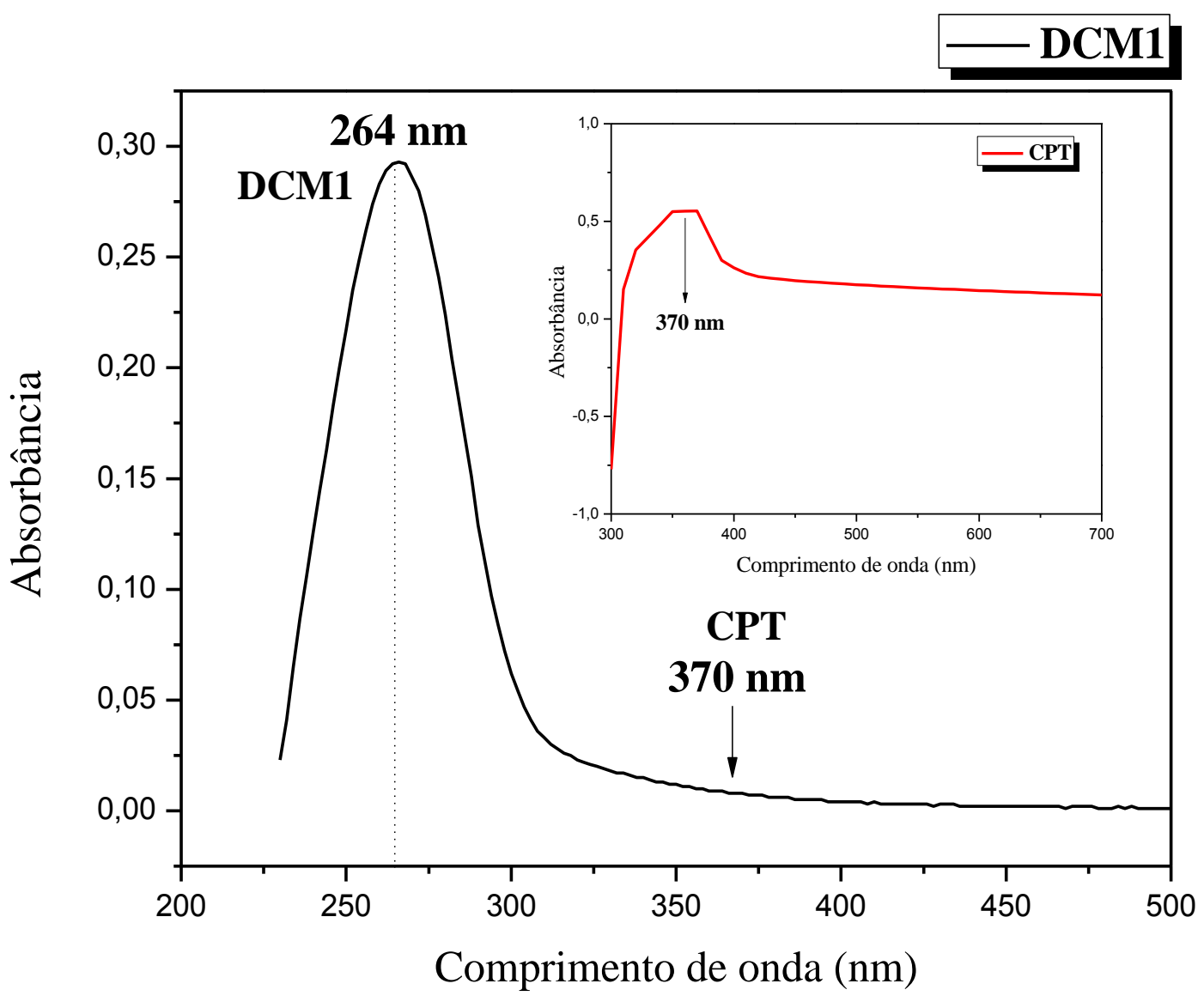




\subsubsection{Linearidade}

Avaliação da linearidade e intervalo é apresentada através do gráfico da curva analítica, que é a relação entre a resposta do equipamento e a concentração conhecida do analito, onde a resposta avaliada foi a absorbância. A Figura 37 apresenta a curva analítica do CPT no intervalo linear de 5 a $100 \mu \mathrm{g} \mathrm{mL}^{-1}$, onde também são apresentados os dados obtidos a partir da regressão linear para a curva analítica.

Por meio dos resultados obtidos a linearidade do método proposto para o intervalo de 5 a $100 \mu \mathrm{g} \mathrm{mL}^{-1}$ confirmou que análise está em conformidade com o indicado pela legislação (BRASIL, 2003)., resultando em elevado valor de coeficiente de correlação linear $\left(r^{2}=0,998\right)$.

Figura 37: Curva analítica da absorbância em função da concentração de CPT, obtida por espectrofotometria na região do UV, com comprimento de onda máxima absorção em $370 \mathrm{~nm}$.

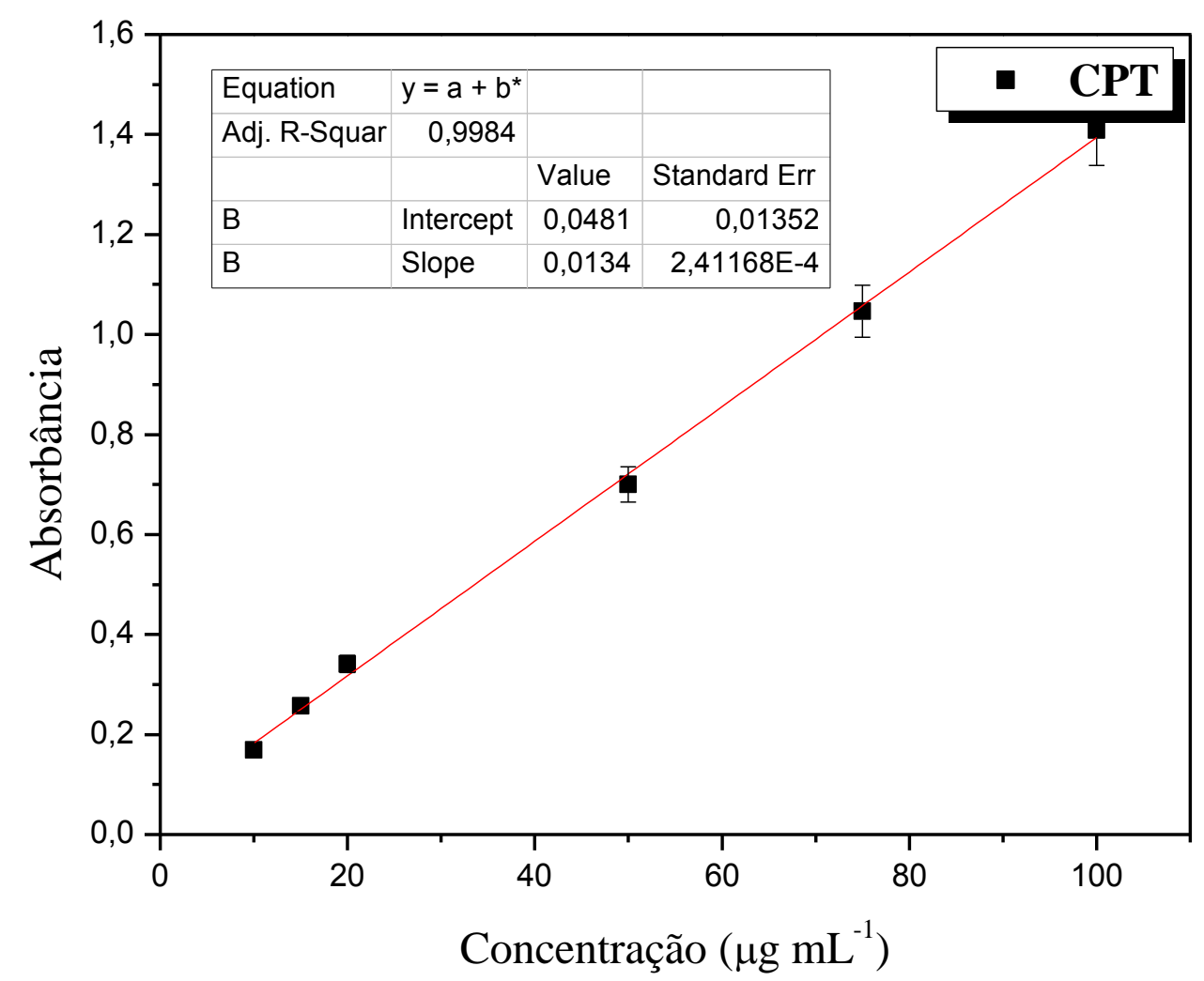




\subsubsection{Precisão}

A precisão de um método refere-se ao grau de concordância dos resultados obtidos quando uma metodologia analítica é aplicada repetidamente, sendo que a precisão é analisada intra-dia e inter-dias. Na precisão intra-dia a repetição do método é realizada pelo mesmo analista, no mesmo equipamento e com os mesmos reagentes, em um curto intervalo de tempo. Já a precisão inter-dias é obtida através da alteração das condições, tais como, mudança de analista, ou reagente e a utilização do método durante semanas ou meses (CAUSON, 1997).

Os resultados de precisão intra-dia são apresentados na Tabela 11 e os inter-dias na Tabela 12. Com base nos resultados obtidos, pode-se observar que os valores de coeficiente de variação $(\mathrm{CV})$, para tal método, se enquadram e não extrapolam o valor máximo (5\%) exigido pela legislação (BRASIL, 2003). Portanto, os valores obtidos confirmam que o método usado apresenta reprodutibilidade e repetibilidade.

Tabela 11: Precisão intra-dia calculado a partir de três concentrações diferentes em um mesmo dia

\begin{tabular}{cccc}
\hline \multicolumn{4}{c}{ Precisão intra-dia } \\
\hline $\begin{array}{c}\text { Concentração teórica } \\
\left(\boldsymbol{\mu g} \mathbf{~ m L}^{-1}\right)\end{array}$ & $\begin{array}{c}\text { Absorbância } \\
\text { média }\end{array}$ & $\begin{array}{c}\text { Desvio } \\
\text { Padrão }\end{array}$ & CV (\%) \\
\hline 15 & 0,2156 & 0,0109 & 5,016 \\
25 & 0,3502 & 0,0096 & 2,7553 \\
50 & 0,3861 & 0,0014 & 0,3661 \\
\hline
\end{tabular}

Tabela 12: Precisão inter-dias calculado a partir de três concentrações diferentes

Precisão inter-dias

\begin{tabular}{cccc}
\hline $\begin{array}{c}\text { Concentração teórica } \\
\left(\boldsymbol{\mu g} \mathbf{~ m L}^{-1}\right)\end{array}$ & $\begin{array}{c}\text { Absorbância } \\
\text { média }\end{array}$ & $\begin{array}{c}\text { Desvio } \\
\text { Padrão }\end{array}$ & $\mathbf{C V}(\boldsymbol{\%})$ \\
\hline 15 & 0,2302 & 0,0109 & 4,76 \\
25 & 0,3510 & 0,0081 & 2,31 \\
50 & 0,6187 & 0,0153 & 4,09 \\
\hline
\end{tabular}




\subsubsection{Exatidão}

A exatidão de uma medida na validação de um método está relacionada ao erro sistemático, sendo expressa como a concordância entre o valor determinado e o real, sendo então a relação entre a concentração média determinada experimentalmente e a concentração teórica (CAUSON, 1997).

Segundo a legislação são aceitas as variações na faixa de $80-120 \%$, no entanto os valores mais próximos de 100\%, condizem a um método mais exato (BRASIL, 2003). Desta forma, podese concluir através dos resultados apresentados na Tabela 13, que a metodologia empregada atende aos requisitos de acordo com a legislação, sendo então adequada para quantificação de CPT.

Tabela 13: Valores de exatidão calculados para as diferentes concentrações de CPT

\begin{tabular}{ccc}
\hline \multicolumn{3}{c}{ Exatidão } \\
\hline $\begin{array}{c}\text { Concentração } \\
\text { teórica }\left(\boldsymbol{\mu g} \mathbf{~ m L}^{-1}\right)\end{array}$ & $\begin{array}{c}\text { Concentração média } \\
\text { experimental }\left(\boldsymbol{\mu g} \mathbf{~ m L}^{-1}\right)\end{array}$ & Exatidão $(\%)$ \\
\hline 15 & 15,83 & 106 \\
25 & 26,62 & 106 \\
50 & 51,08 & 102 \\
\hline
\end{tabular}

\subsubsection{Limites de detecção (LD) e quantificação (LQ)}

Segundo a legislação 899/03, é definido que o limite de detecção é a menor quantidade de analito encontrado em uma amostra capaz de ser detectável, no entanto não necessariamente quantificado. Em compensação, o limite mínimo de quantificação deve representar a menor concentração que pode ser determinada com exatidão e precisão.

Dessa forma os valores de LD e LQ obtidos são apresentados na Tabela 13 e mostram que a metodologia empregada é capaz de detectar e quantificar com precisão e exatidão baixas concentrações $\left(\mathrm{LD}=0,236 \mathrm{e} \mathrm{LQ}=0,789 \mathrm{~mol} \mathrm{~L}^{-1}\right)$ de CPT. 
Após finalizar o processo de validação do método de quantificação de CPT através da técnica de espectroscopia de UV, a eficiência de encapsulação do fármaco foi realizada. Os valores de eficiência de encapsulação (EE\%) de CPT das micelas de QCM1 em função da concentração de CPT são apresentados na Tabela 14. Estes dados mostram que EE\% diminuiu com o aumento da concentração de CPT, sendo a eficiência máxima de encapsulação alcançada quando a menor carga de CPT foi empregada. Tal resultado sugere que a capacidade das micelas QMC1 para carregar CPT pode depender do $\overline{D S}$ do derivado de quitosana, e a eficiência de encapsulação é limitada pelo conteúdo de substituintes miristoíla ao longo das cadeias poliméricas. Assim, levando em consideração o baixo teor de grupos miristoíla nas cadeias QCM1, a carga reduzida de CPT é observada para altas cargas de fármaco e pode ser atribuída à baixa densidade de segmentos hidrofóbicos de polímero no núcleo das micelas de QCM1.

Tabela 14: Valores de diâmetro, índice de polidispersidade (PDI), potencial zeta e eficiência de encapsulação das micelas QCM1

\begin{tabular}{cccccc}
\hline & & \multicolumn{4}{c}{ Parâmetros } \\
\cline { 3 - 6 } Amostra & CPT (\%) & $\begin{array}{c}\text { Diâmetro médio } \\
(\mathbf{n m})\end{array}$ & PDI $^{\mathbf{a}}$ & $\begin{array}{c}\text { Potencial zeta } \\
\mathbf{a}(\mathbf{m V})\end{array}$ & $\mathbf{E E ~ ( \% )}$ \\
\hline QCM & 0 & $357 \pm 21$ & $0,5 \pm 0,03$ & $32 \pm 4$ & - \\
QCM1-CPT1 & 1 & $282 \pm 17$ & $0,5 \pm 0,04$ & $43 \pm 2$ & $100^{*}$ \\
QCM1-CPT2 & 2 & $289 \pm 38$ & $0,4 \pm 0,04$ & $46 \pm 0,2$ & $70 \pm 1$ \\
QCM1-CPT3 & 3 & $336 \pm 16$ & $0,4 \pm 0,2$ & $50 \pm 4$ & $42 \pm 1$ \\
\hline
\end{tabular}

a) Diâmetro, índice de polidispersividade e potencial zeta foram determinadas por espelhamento dinâmico de luz (DLS), b) Eficiência de encapsulação. * Abaixo do limite de detecção por HPLC. Os valores foram relatados como média \pm DP $(n=3)$. \# Todas as formulações apresentaram perfil monomodal.

\subsubsection{Tamanho e morfologia}

\subsubsection{Diâmetro médio, índice de polidispersividade e potencial zeta}

Os dados experimentais referentes ao diâmetro médio, índice de polidispersidade (PDI) e potencial zeta das micelas QCM1 vazias e carregadas com CPT (Tabela 14), revelam que a 
encapsulação de CPT teve pouca influência sobre o diâmetro médio das micelas, sendo observado que o diâmetro variou no intervalo $281 \mathrm{~nm}-357 \mathrm{~nm}$.

Adicionalmente, independentemente da presença e da concentração de CPT, os diagramas de distribuição de tamanho das micelas foram do tipo monomodal (Figura 38), sendo a curva apresentada representativa para todas as amostras, sendo que estas apresentaram $\mathrm{PDI} \leq 0,525$.

Figura 38: Curva de distribuição de tamanho por intensidade de espalhamento de luz da QCM1-CPT2, representativo para todas as demais amostras.

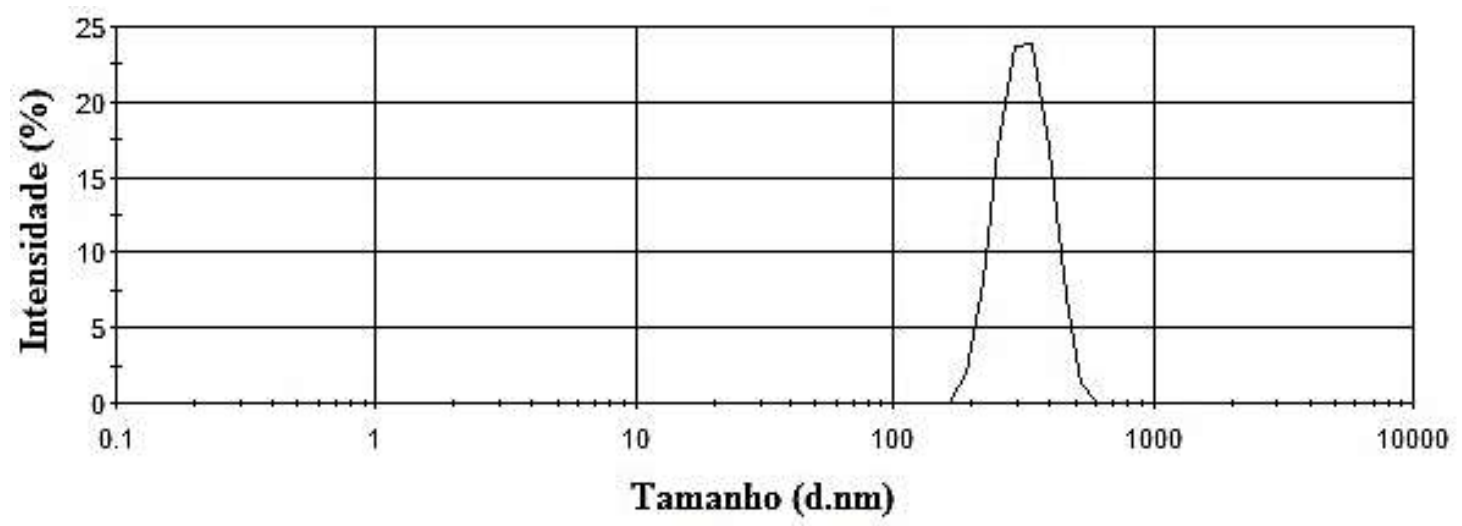

As medidas de potencial zeta permitiram avaliar a contribuição de forças eletrostáticas repulsivas para estabilizar as micelas QCM1/CPT. Por conseguinte, tais medições mostraram valores positivos de potencial zeta $(+32 \mathrm{mV} /+50 \mathrm{mV})$, que são atribuídos à presença de grupos amônio na região hidrofílica das micelas, resultantes da protonação de grupos amino pertencentes às unidades 2-amino-2-desoxi-D-glucopiranose presentes nas cadeias do polímero. De fato, como a quitosana de partida apresentou baixo grau de acetilação $(\overline{D A}=5 \%)$ e a sua reação com cloreto de miristoil ocorreu predominantemente nos grupos hidroxila (SILVA et al., 2017), as cadeias do derivado QCM1 apresentam uma parcela significativa de grupos amino, gerando uma densidade de carga positiva elevada após a protonação.

Assim, a elevada densidade de carga positiva no invólucro hidrofílico das micelas contribui fortemente para estabilizá-las e também favorece as interações das micelas com a parede celular carregada negativamente, resultando em absorção e penetração aumentadas de CPT. 


\subsubsection{Microscopia Eletrônica de Transmissão (MET)}

A análise de microscopia eletrônica de transmissão foi realizada com objetivo de confirmar os resultados obtidos por DLS e também para verificar o formato das micelas obtidas. As micelas de QCM1 carregadas com CPT são apresentadas na Figura 39. Conforme mostrado nas imagens de MET, foi possível observar que as micelas apresentaram formas esféricas com diâmetros de aproximadamente 277 a $350 \mathrm{~nm}$, enquanto que os diâmetros obtidos por DLS foram de 280 a $356 \mathrm{~nm}$, variando de acordo com sua carga de fármaco.

Figura 39: Imagens de MET que mostram a forma e o tamanho de DMC*-CPT2, com escala correspondente a (a) $100 \mathrm{~nm}$ e (b) $200 \mathrm{~nm}$.

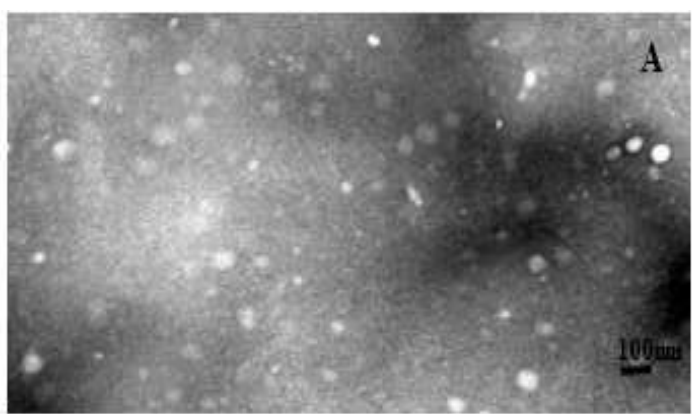

(a)

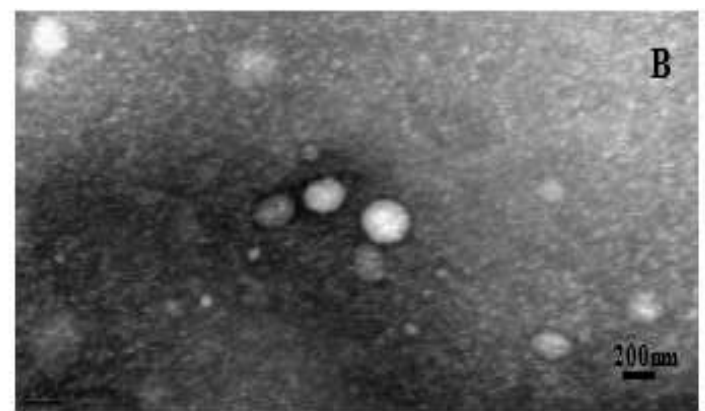

(b)

\subsubsection{Avaliação da citotoxicidade}

De acordo com os resultados apresentados anteriormente, o sistema carreado com CPT escolhido para realizar o ensaio biológico foi QCM1-CPT2 devido à sua maior capacidade de encapsulação e solubilização de CPT. A citotoxicidade in vitro de QCM1, QCM1-CPT2 e CPT livre foram avaliadas em linhas de células epiteliais intestinais Caco-2 e HT29-MTX pelo ensaio de MTT.

Os resultados da viabilidade celular após $24 \mathrm{~h}$ de incubação na presença de concentrações crescentes das amostras são mostrados nas Figura 40 e Figura 41. Foi observado que o derivado de quitosana QCM1 não apresentou efeitos tóxicos em relação a nenhuma linha celular nos intervalos de concentrações avaliados, mostrando seu potencial para ser usado na preparação de micelas destinadas a liberação do fármaco no intestino. 
Em baixas concentrações $\left(\leq 10 \mu \mathrm{g} \mathrm{mL} \mathrm{m}^{-1}\right)$, verificou-se que as viabilidades das células eram superiores a 80\% para todas as concentrações de micelas QCM1-CPT2 e CPT livre. No entanto, a viabilidade celular de ambas as linhas celulares diminuiu significativamente após a incubação com $100 \mu \mathrm{g} \mathrm{mL}^{-1}$ de CPT livre. Todavia, esta quantidade de CPT carregada nas micelas QCM1 não diminuiu a viabilidade celular das células Caco-2 ou HT29-MTX, mostrando a capacidade destas micelas reduzir a toxicidade do fármaco. Estes resultados estão de acordo com outros estudos realizados com diferentes sistemas poliméricos, no qual foi usado concentrações semelhantes de CPT, para as mesmas linhas celulares assim como para outras linhagens celulares (KOLHATKAR; SWAAN; GHANDEHARI, 2008; DUAN et al., 2010; OMAR et al., 2016).

Figura 40: A viabilidade celular de QCM1, QCM1- CPT2 e CPT livre, contra a linha celular Caco-2 nas concentrações de 0,001-100 $\mu \mathrm{g} \mathrm{mL}^{\mathbf{1}}$ após incubação durante $24 \mathrm{~h}$. Os valores foram relatados como média \pm DP $(\mathrm{n}=3)$. $(* *)$ e $(* * *)$ denota uma diferença significativa.

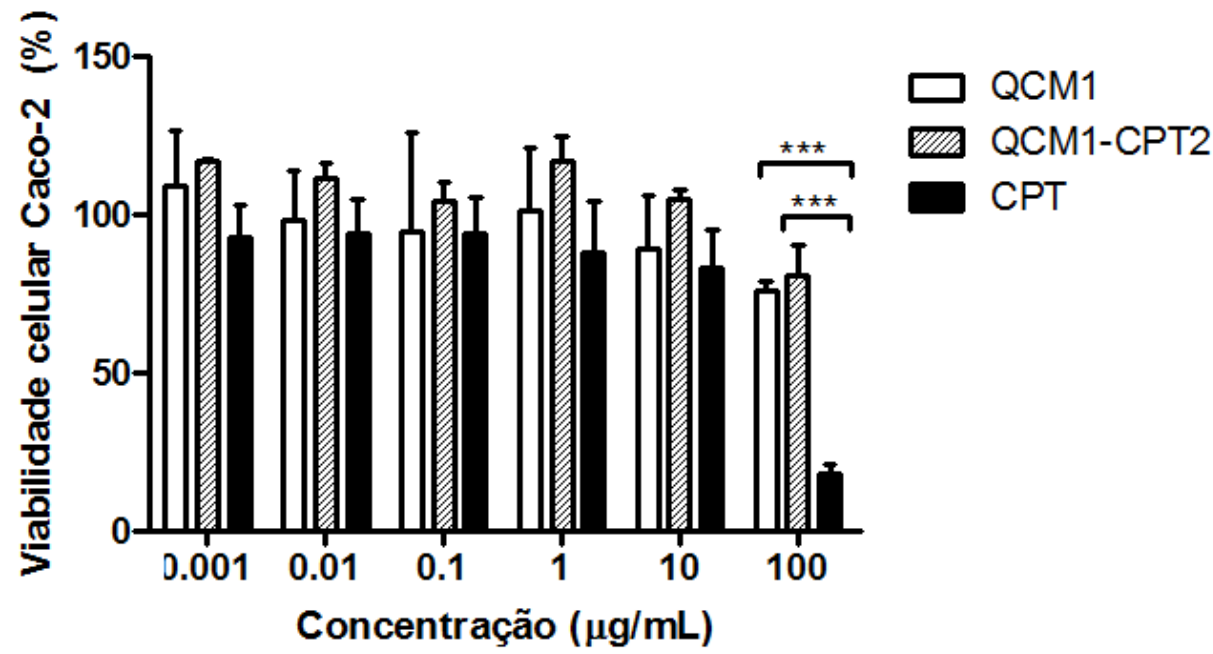

A linhagem celular HT29-MTX apresentou maior sensibilidade ao CPT livre quando comparado ao modelo Caco-2. Os resultados também mostraram que as micelas QCM1 e QCM1-CPT2 não apresentaram citotoxicidade, mas o CPT livre mostrou uma toxicidade considerável. Adicionalmente, tais resultados mostraram que, além de serem atóxicos, as micelas de QCM1 reduziram significativamente os efeitos tóxicos do CPT. 
Figura 41: A viabilidade celular de QCM1, QCM1- CPT e CPT livre, contra a linha celular HT29-MTX nas concentrações de 0,001-100 $\mu \mathrm{g} \mathrm{mL} \mathrm{m}^{\mathbf{1}}$ após incubação durante $24 \mathrm{~h}$. Os valores foram relatados como média \pm $\mathrm{DP}(\mathrm{n}=3)$. $(* *)$ e $(* * *)$ denota uma diferença significativa.

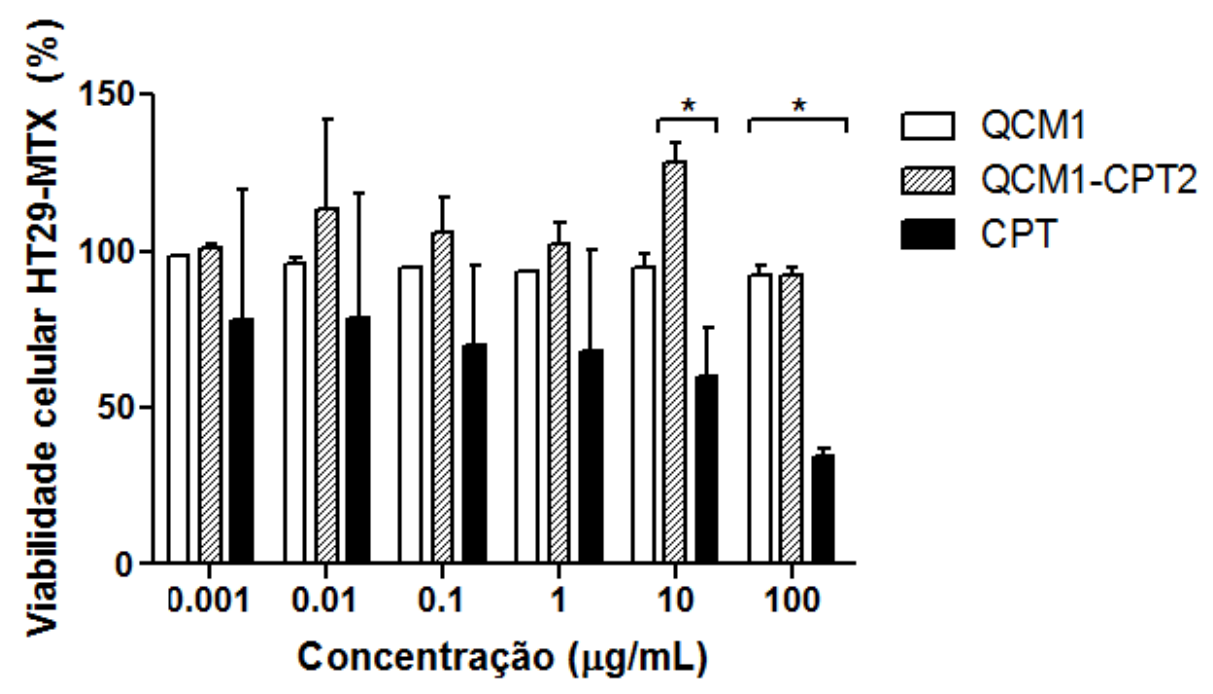

\subsubsection{Avaliação da permeabilidade in vitro em monocultura de células Caco-2 e co-cultura (Caco-2 /HT29-MTX)}

A permeabilidade de CPT através das células epiteliais intestinais foi estudada com objetivo de investigar a influência das micelas de QCM1 sobre a melhora da permeabilidade de CPT através das barreiras biológicas, provindas dos modelos celulares propostos neste trabalho. Assim, foi utilizado um modelo de monocultura constituído por células Caco-2, que representa o modelo padrão que imita enterócitos humanos. Adicionalmente, utilizou-se o modelo de cocultura Caco-2/HT29-MTX para mimetizar melhor o intestino humano quando comparado as células Caco-2 isoladas, uma vez que HT29-MTX são células secretoras de muco.

Os modelos celulares foram semeados em inserts e a medida de TEER foi realizada em diferentes dias e conforme os resultados apresentados na Figura 42 e Figura 43, assim monitorando a integridade epitelial das monocamadas, que à medida que crescem tem os valores de TEER aumentados. Ao término dos 21 dias os modelos de monocultura apresentaram valores de TEER de aproximadamente 700 a $1000 \Omega . \mathrm{cm}^{2}$ e os modelos de co- 
cultura apresentaram valores de aproximadamente $300 \Omega . \mathrm{cm}^{2}$, valores adequados para o uso das monocamadas nos ensaios de permeabilidade.

Figura 42: Gráfico dos valores de TEER em função do tempo, medido durante os 21 dias de formação da monocamada para o modelo de monocultura (células Caco-2).

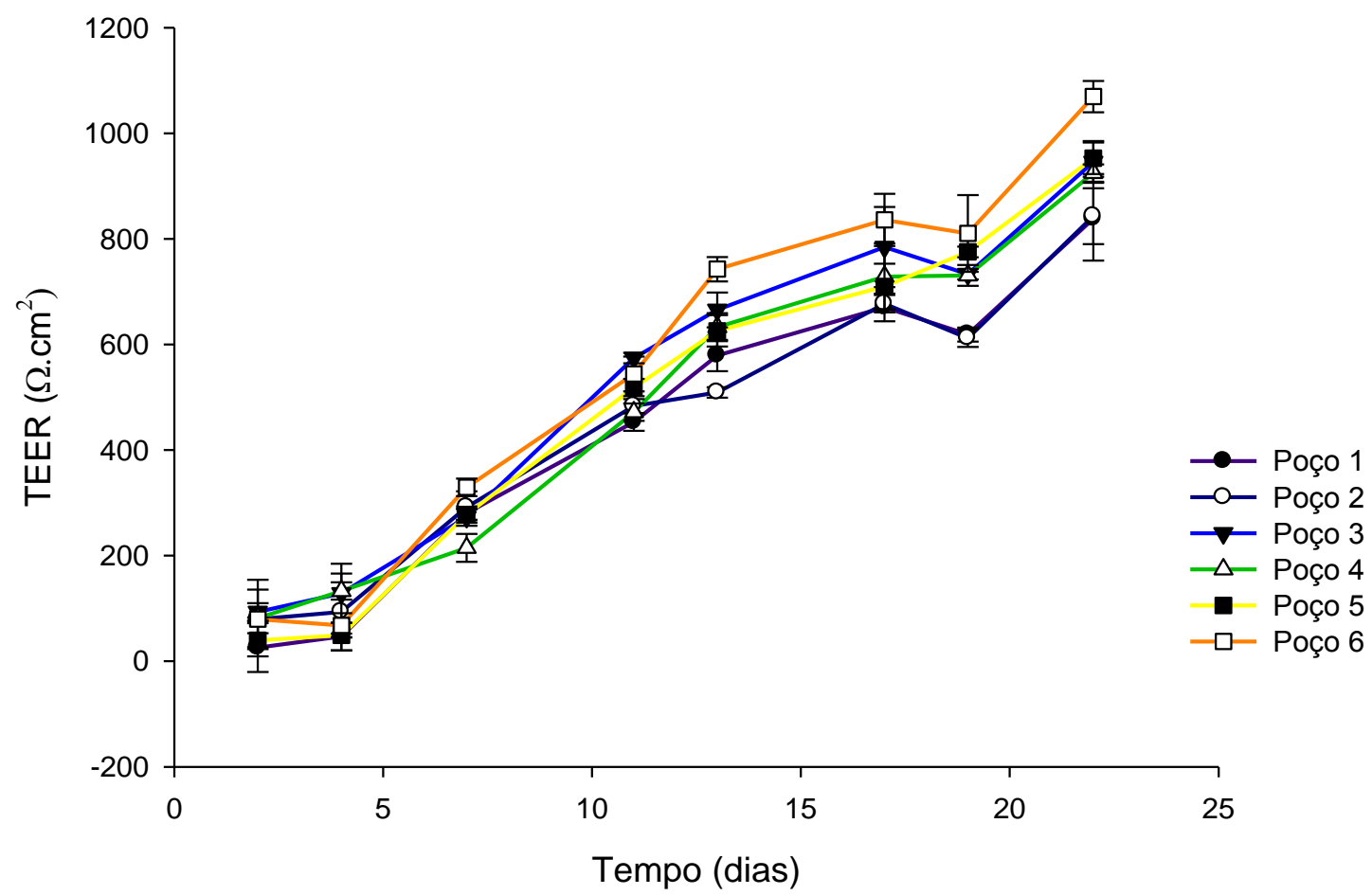

Após os 21 dias, o ensaio de permeabilidade foi realizado a fim de avaliar o efeito do derivado de quitosana sobre a permeabilidade de CPT in vitro. De acordo com os resultados apresentados na Figura 44 e Figura 45, a permeabilidade de CPT através das células epiteliais alcançou aproximadamente $13 \%$ e $30 \%$ para os modelos de monocultura e de co-cultura, respectivamente, evidenciando a expressiva melhora da permeabilidade devida às micelas QCM1-CPT2, pois tais resultados também mostram permeabilidade de apenas 1,6\% quando CPT livre foi ensaiado com o modelo de co-cultura. A maior permeabilidade observada nos ensaios com o sistema QCM1/ CPT2 pode ser atribuída à mucoadesividade da quitosana, decorrente da presença de grupos amônio ao longo das cadeias polímericas, que favorecem as interações entre as micelas e o muco produzido pelas células HT29-MTX, melhorando a permeabilidade de CPT 
através da barreira intestinal. Os resultados apresentados estão em concordância com os resultados obtidos com PTX (ALMEIDA et al., 2017; SILVA et al., 2017).

Figura 43: Gráfico dos valores de TEER em função do tempo, medido durante os 21 dias de formação da monocamada para o modelo de co-cultura (células Caco-2/ HT29-MTX).

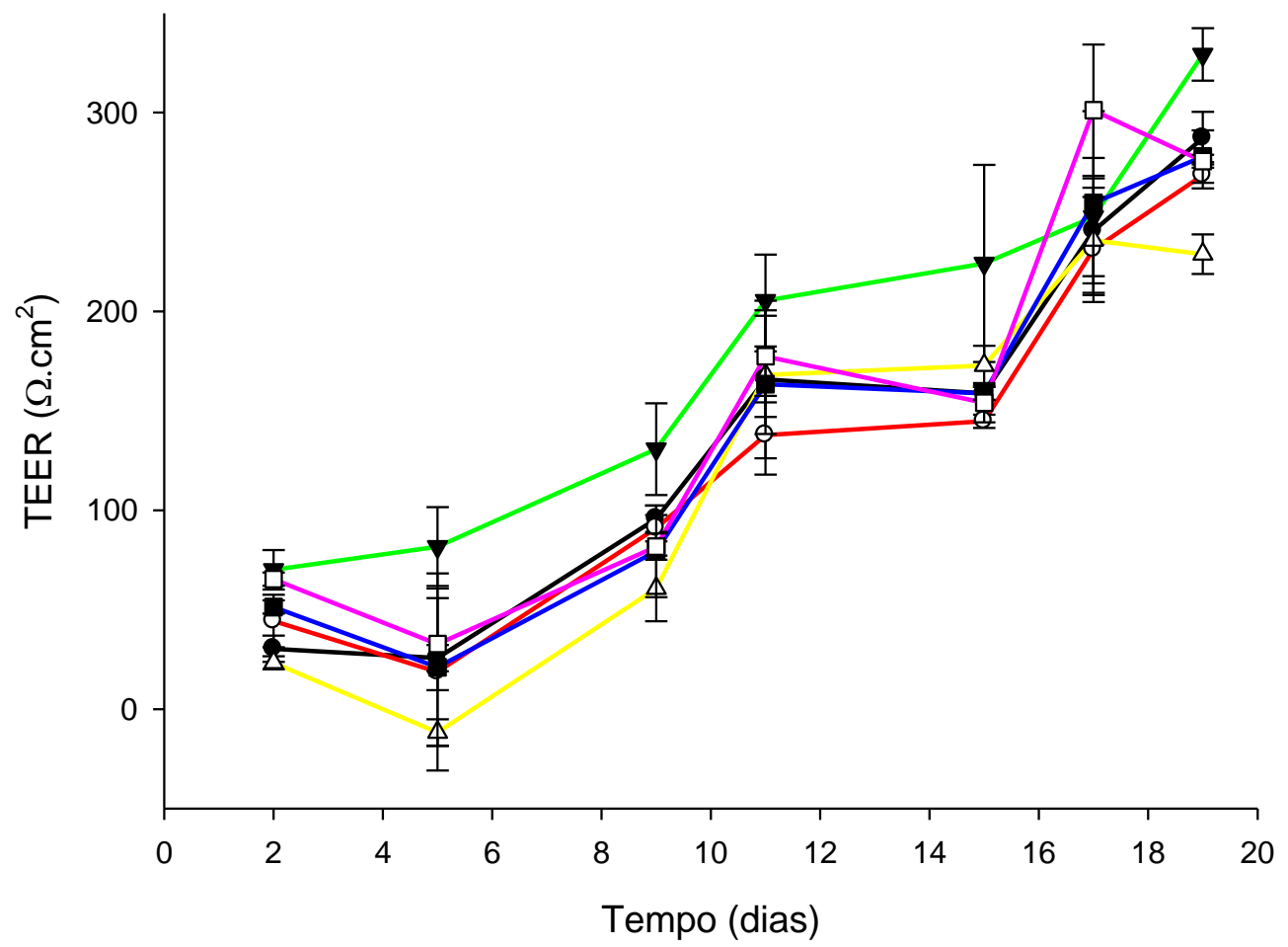

De fato, outros estudos já relataram que a quitosana pode interagir com a camada de muco das barreiras celulares (YUAN et al., 2010; MO et al., 2011). Além disso, também é conhecido que a quitosana é capaz de abrir temporariamente as junções apertadas das células epiteliais, melhorando a permeabilidade através da barreira intestinal (YEH et al., 2011). 
Figura 44: Perfil de permeabilidade cumulativa in vitro de micelas carregadas com CPT através do modelo de monocultura Caco-2 . Todos os experimentos foram conduzidos do compartimento apical ao basolateral em

HBSS a $37^{\circ} \mathrm{C}$. As barras de erro representam a média \pm DP $(\boldsymbol{n}=3)$.

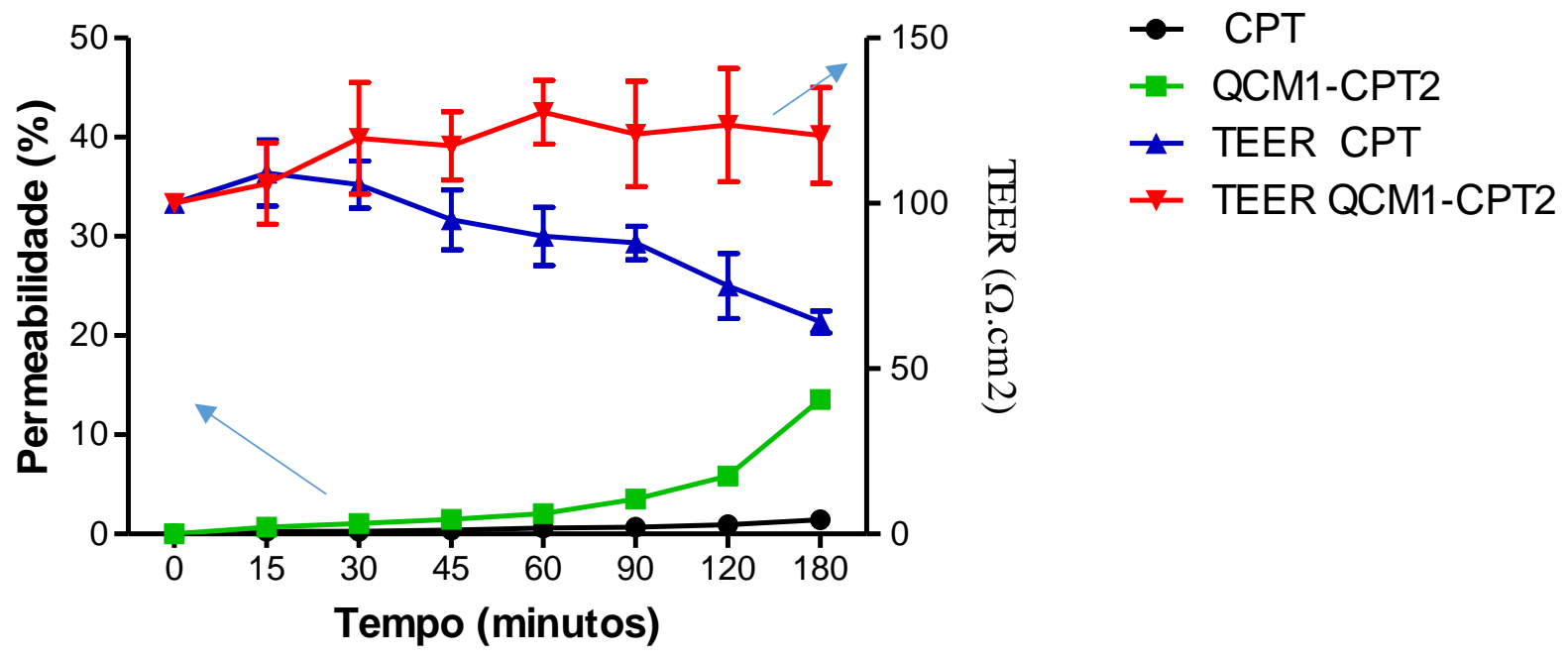

A permeabilidade de CPT ocorreu de forma constante durante todo o experimento, com elevados valores de TEER. O modelo de co-cultura apresentou valores menores de TEER quando comparado com o modelo padrão, devido à presença de células HT29-MTX. As junções estreitas das células HT29-MTX é menor que o das Caco-2, representando menores valores de TEER, o que pode levar a uma maior permeabilidade do fármaco (ARAÚJO; SARMENTO, 2013).

De fato, observou-se um aumento na permeabilidade CPT devido à presença das junções apertadas das células HT29-MTX, combinadas com o muco produzido e a interação das micelas mucoadesivas. No caso de CPT livre, os resultados mostraram uma diminuição nos valores de TEER para aproximadamente 70\%. De fato, esta diminuição não afetou a permeabilidade do CPT como evidenciado na Figura 45.

No geral, as micelas à base de derivados anfifilicos de quitosana, podem aumentar significativamente a permeabilidade de CPT, especialmente no modelo que melhor mimetiza o intestino humano (Caco-2/HT29-MTX). 
Figura 45: Perfil de permeabilidade cumulativa in vitro de micelas carregadas com CPT através do modelo de co-cultura Caco-2 / HT29-MTX. Todos os experimentos foram conduzidos do compartimento apical ao basolateral em HBSS a $37^{\circ} \mathrm{C}$. As barras de erro representam a média \pm DP $(\boldsymbol{n}=3)$.

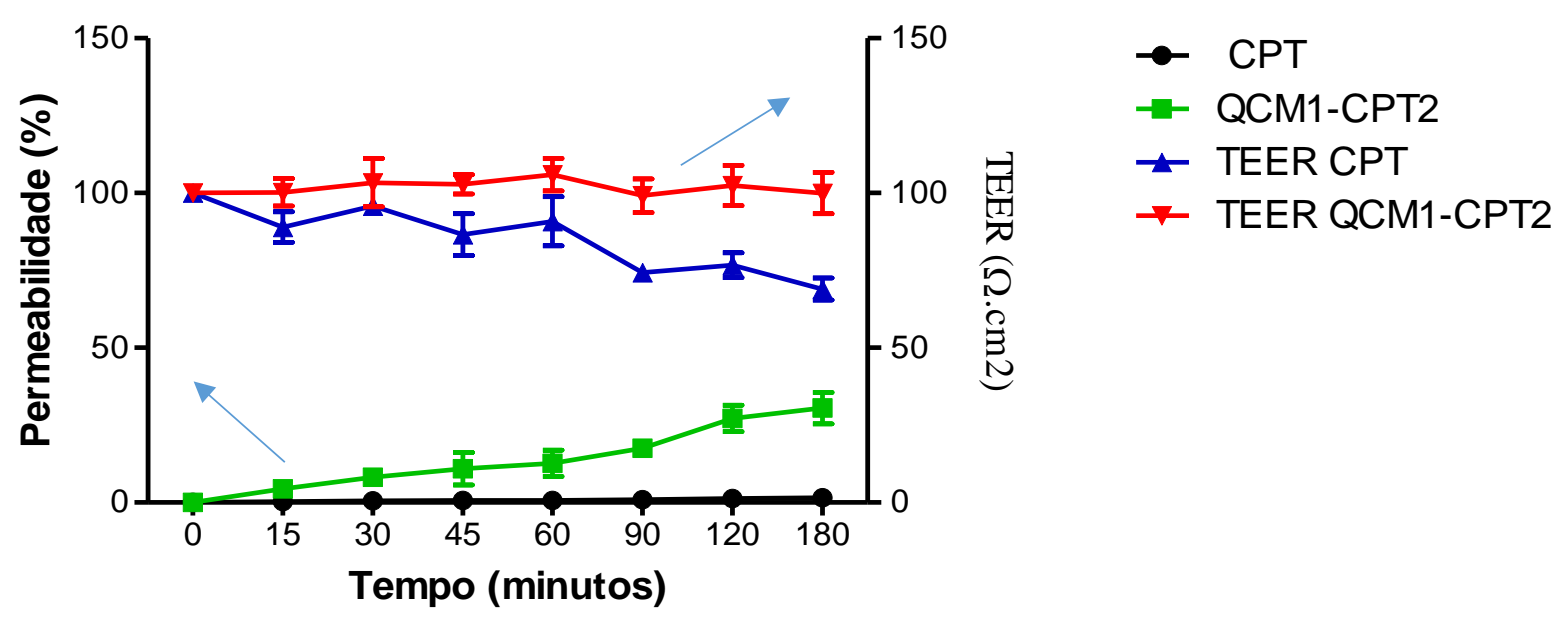

\subsubsection{Liberação in vitro do fármaco}

O perfil de liberação de CPT livre e encapsulado (QCM1-CPT2) foi avaliado em diferentes meios de dissolução, sendo esses capazes de simular os fluídos biológicos gástrico $(\mathrm{pH}=1,2)$ e intestinal $(\mathrm{pH}=6,8)$ simulados sem a presença de enzimas. $\mathrm{O}$ ensaio foi realizado através do método de diálise, e foram coletadas alíquotas em diferentes intervalos de tempo, sendo o intervalo de 0-2 horas para o fluído gástrico e de 2- 48 horas para o fluído intestinal.

O perfil de liberação de CPT livre e QCM1-CPT2 nas primeiras 2 horas (pH 1,2) e durante o período mais longo ( $\mathrm{pH}$ 6,8) são apresentados na Figura 46. No caso de CPT livre, cerca de 90\% da carga total de fármaco foi libertada após 8 h e uma liberação quase completa foi observada após 12 horas, enquanto que $21 \%$ da carga total de CPT foi libertada das micelas QCM*1-CPT2 no mesmo tempo intervalo.

De fato, o fármaco carregado nas micelas foi rapidamente liberado durante a primeira hora Figura 47, seguido por uma liberação controlada até ao final do ensaio. Ao longo do experimento não foi observado uma liberação dependente do $\mathrm{pH}$, a liberação do fármaco foi contínua e 
independente do pH do meio até 2 h, e ocorreu um perfil de liberação linear e constante, variando entre $20-24 \%$ de CPT no FISE com $\mathrm{pH}=6,8$.

Figura 46: O perfil de liberação de camptotecina após incubação em fluido gástrico simulado (FGSE) (0-2 h) e fluido intestinal simulado (FISE) $\left(2-48 \mathrm{~h}\right.$ ) sob condições de lavagem a $37^{\circ} \mathrm{C}$. A). Dados correspondentes ao perfil de libertação durante 48 h. Dados expressos como Média \pm DP, $n=3$.

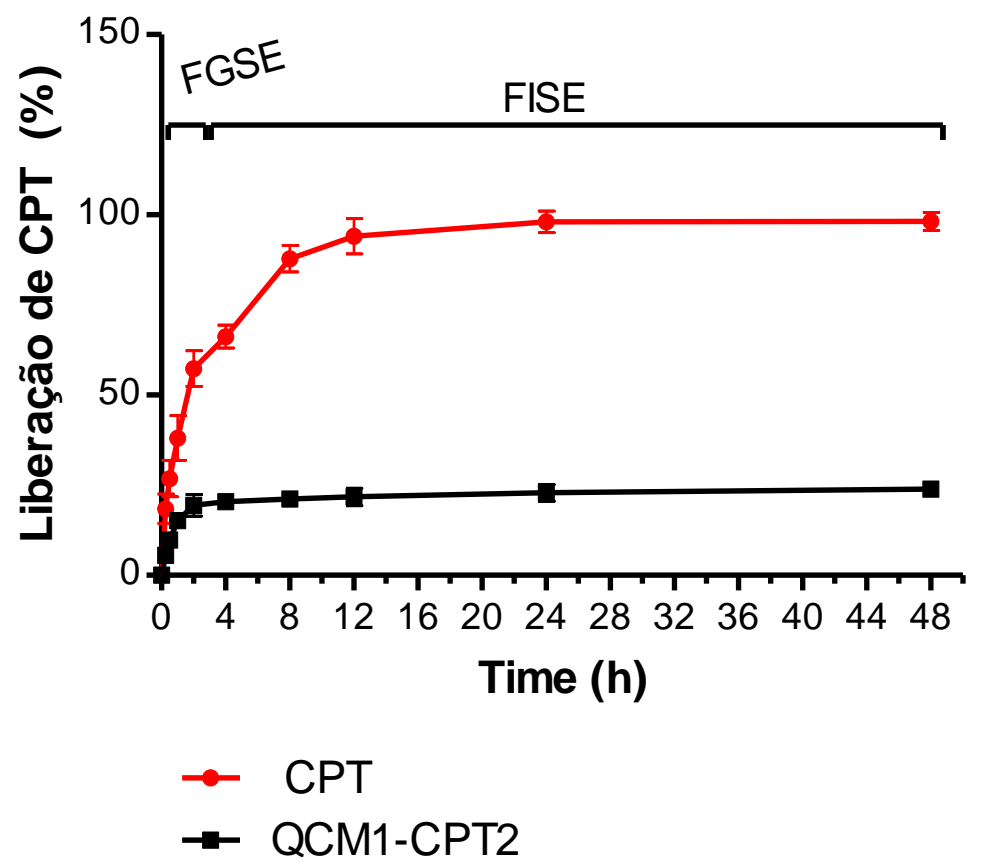

A baixa quantidade de CPT liberado nas micelas são justificados por fatores que tem influência direta na liberação, quando o carreador se trata de um polímero derivado de quitosana. Primeiramente, o processo usado na encapsulação foi a micelização, nesse procedimento o fármaco permanece no interior da micela, o que favorece uma liberação do tipo sustentada, ocorrendo liberação através da degradação do polímero ou por meio de difusão (CHAUVIERRE et al., 2007; PARK et al., 2010; BERNKOP-SCHNÜRCH; DÜNNHAUPT, 2012; TAVARES, 2013). O ensaio de liberação foi realizado em fluídos biológicos simulados sem a presença de enzimas, e estas são as responsáveis por realizar o processo de degradação do derivado de quitosana a partir da quebra das ligações glicosídicas, sendo assim, na ausência das enzimas a liberação do fármaco nesse ensaio foi realizada apenas por meio da difusão através da parede do polímero (TOZAKI et al., 1997; HEJAZI; AMIJI, 2003; PARK et al., 2010). 
Assim, foi verificado que para um ensaio nas condições adequadas ou um ensaio in vitro com enzimas capazes de degradar o polímero, resultados com um perfil de liberação melhor pode ser obtido. Além disso, os resultados do estudo de liberação de CPT in vitro mostraram que as micelas de QCM1 são transportadoras adequadas para a CPT.

Figura 47: Gráfico correspondente a ampliação da Figura 46 no intervalo de tempo de 0-4 horas.

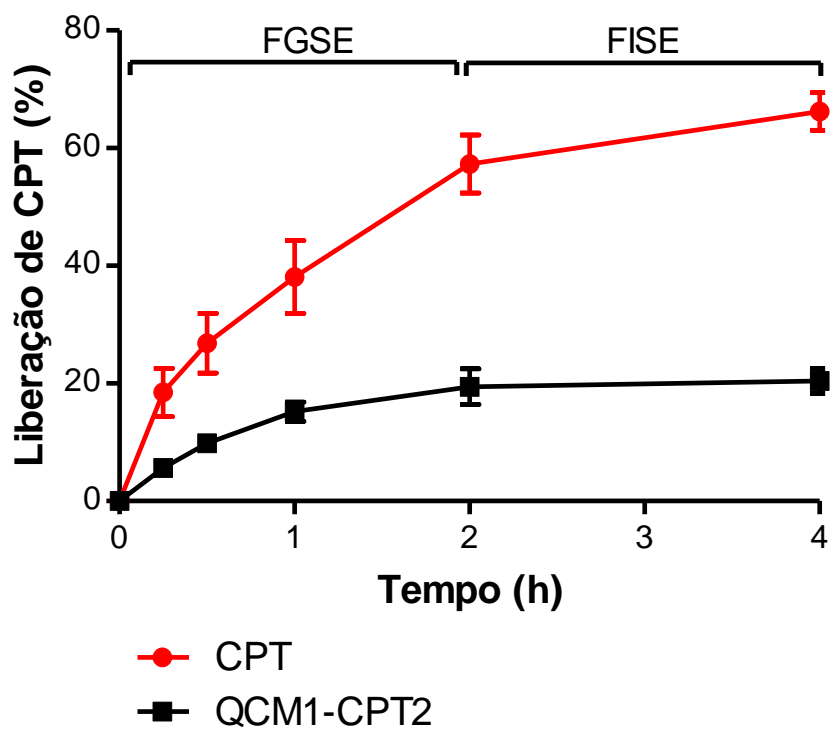

\subsubsection{Conclusão}

O comportamento de auto-agregação das cadeias de 3,6-O,O'-dimiristoil-quitosana (QCM1) em meio aquoso resulta na formação de micelas apresentando arquitetura núcleo / casca, as quais são capazes de encapsular camptotecina (CPT), insolúvel em água, no seu núcleo hidrofóbico. As micelas nano-dimensionadas carregadas com CPT (281 nm - 357 nm) são estabilizadas por forças eletrostáticas repulsivas, devido à presença de numerosas cargas positivas na superfície hidrofílica das micelas de QCM1, devido à protonação de grupos amino pertencentes a unidades 2-amino -2-desoxi-D-glupiranose. A liberação in vitro de CPT a partir das micelas de QCM1/CPT2 não é dependente do pH e é observada uma liberação sustentada após 2 horas, suportando a proposta das micelas de QCM1 como transportadoras adequadas para administração oral de CPT. As micelas QCM1 vazias exibem toxicidade muito baixa e embora o 
CPT livre exiba alta toxicidade em relação às linhas celulares epiteliais intestinais Caco-2 e HT29-MTX a uma concentração de $100 \mu \mathrm{g} \mathrm{mL} \mathrm{m}^{-1}$, a sua encapsulação em micelas de QCM1 diminui fortemente a toxicidade do fármaco, melhorando a segurança da administração oral de CPT. Devido à mucoadesividade das micelas QCM1/CPT2, que é principalmente devido ao seu potencial zeta positivo $(>+30 \mathrm{mV})$, elas são capazes de interagir com o muco carregado negativamente produzido pelas células HT29-MTX e abrir temporariamente as junções apertadas das células, melhorando a permeabilidade in vitro de CPT através da barreira intestinal e aumentando a sua biodisponibilidade. O conjunto completo de resultados indica claramente o elevado potencial das micelas de QCM1 para encapsular e libertar de forma segura a camptotecina via administração oral. 


\section{CONSIDERAÇÕES FINAIS}

A primeira parte do presente estudo tem como principal contribuição a produção do derivado de quitosana com características hidrofóbicas obtido via $O$-acilação, sendo este um diferencial importante dos demais trabalhos encontrados na literatura- Adicionalmente, a variação da razão molar quitosana/agente acilante contribui para obtenção de um derivado com as características desejáveis.

As micelas de QCM1 e QCM4 foram capazes de encapsular fármacos hidrofóbicos, sendo que houve diferenças significativas de eficiências de encapsulação entre os diferentes tipos de fármacos, fato que pode ser explicado pela maior hidrofobicidade de CPT quando comparado ao PTX. Os diâmetros médios das micelas vazias e carregadas variaram na faixa de $280-481 \mathrm{~nm}$, para as diferentes micelas e fármacos, sendo que os menores diâmetros foram obtidos para as micelas QCM1 carregadas com CPT. Os valores de potencial zeta para todos os sistemas foram $\geq+30 \mathrm{mV}$, sendo estes resultados interessantes para os estudos de interação dos modelos celulares.

Em relação aos estudos in vitro os resultados mostram que as micelas à base de DMQ são potenciais candidatas promissoras para o uso como carreadoras de fármacos hidrofóbicos, capazes de melhor a permeabilidade in vitro dos fármacos através da barreira intestinal e aumentar a sua biodisponibilidade. 


\section{PERSPECTIVAS FUTURAS}

- Realizar sínteses via $N$-substituição e $O$-substituição com intuito de obter derivados de quitosana anfifílicos, com porções hidrofóbicas constituídas por grupos miristoíla, conforme o derivado usado nesse trabalho (3,6-O, $O^{\prime}$-dimiristoilquitosana), e porções hidrofílicas que contenham grupos carboximetilados e grupos cationizados. Obtendo esses derivados seria de interesse avaliar suas propriedades físico-químicas, afim de obter derivados capazes de funcionar como carreadores de fármacos hidrofóbicos. E por fim, avaliar a interação desses polímeros com modelos celulares frente a citotoxicidade e a capacidade de permeabilidade dos fármacos encapsulados nos derivados anfifílicos de quitosana.

- Sintetizar e caracterizar polímeros com propriedades anfifílicas preparados a partir de quitosana, que sejam capazes de carregar fármacos hidrofóbicos e aplicá-los como camada externa de micromotores, dispositivos que convertem localmente reações produtoras de combustíveis ou energia fornecida pelo meio externo em movimento, sua capacidade de transporte ativo e resposta ao ambiente são promissoras para entrega localizada de fármacos.

- Produzir micelas capazes de encapsular fármacos hidrofóbicos e que apresentem características ótimas em função do diâmetro médio e eficiência de encapsulação para recobrir micromotores com características de pH-sensitivo e assim avaliar este sistema através de ensaios in vitro. 
ABDOU, E. S.; NAGY, K. S.; ELSABEE, M. Z. Extraction and characterization of chitin and chitosan from local sources. Bioresource Technology, v. 99, n. 5, p. 1359-67, 2008.

ACKCELRUD, L. Fundamentos da ciência dos polímeros. São Paulo: Manole, 2007. 308 p.

AGNIHOTRI, S.; MALLIKARJUNA, N. N.; AMINABHAVI, T. M. Recent advances on chitosan-based micro- and nanoparticles in drug delivery. Journal of Controlled Release :

Official Journal of the Controlled Release Society, v. 100, n. 1, p. 5-28, 2004.

ALMEIDA, A.; SILVA, D.; GONÇALVES, V.; SARMENTO, B. Synthesis and characterization of chitosan-grafted-polycaprolactone micelles for modulate intestinal paclitaxel delivery. Drug Delivery and Translational Research, v. 7, n. 36, p. 1-11, 2017.

ANTUNES, F.; ANDRADE, F.; ARAÚJO, F.; FERREIRA, D.; SARMENTO, B.

Establishment of a triple co-culture in vitro cell models to study intestinal absorption of peptide drugs. European Journal of Pharmaceutics and Biopharmaceutics, v. 83, n. 3, p. 427-435, 2013.

ARAÚJO, F.; SARMENTO, B. Towards the characterization of an in vitro triple co-culture intestine cell model for permeability studies. International Journal of Pharmaceutics, v. 458, n. 1, p. 128-134, 2013.

ASTAFIEVA, I.; ZHONG, X. F.; EISENBERG, A. Critical micellization phenomena in block polyelectrolyte solutions. Macromolecules, v. 26, p. 7339-7352, 1993.

BADAWY, M. E. I.; RABEA, E. I.; ROGGE, T. M.; STEVENS, C. V.; STEURBAUT, W.; HÖFTE, M.; SMAGGHE, G. Fungicidal and insecticidal activity of O-acyl chitosan derivatives. Polymer Bulletin, v. 54, n. 4-5, p. 279-289, 2005.

BADAWY, M. E. I.; RABEA, E. I.; ROGGE, T. M.; STEVENS, C. V; SMAGGHE, G.; STEURBAUT, W.; HO, M. Synthesis and fungicidal activity of new N, O-acyl chitosan derivatives. Biomacromolecules, p. 589-595, 2004.

BALAN, V.; BUTNARU, M.; VERESTIUC, L. Synthesis and characterization of magnetic nanoparticles based on $N$-palmitoyl-chitosan with potential applications in cancer theranostics. In: IEEE INTERNATIONAL CONFERENCE ON E-HEALTH AND BIOENGINEERING ( EHB), 4., Iase, Romania.Proceedings... IEEE, 2013.p. 1-4. 
BATTISTI, M. V.; CAMPANA-FILHO, S. P. Obtenção e caracterização de $\alpha$-quitina e quitosanas de cascas de Macrobrachium rosembergii. Quimica Nova, v. 31, n. 8, p. 2014 2019, 2008.

BEI, Y.; YUAN, Z.; ZHANG, L.; ZHOU, X. Novel self-assembled micelles based on palmitoyl-trimethyl- chitosan for efficient delivery of harmine to liver cancer.Expert Opinion, p. 843-854, 2014.

BELLAMY, W. T. Prediction of response to drug therapy of cancer. A review of in vitro assays. Drugs, v. 44, n. 5, p. 690-708, 1992.

BELTRAME, P. L.; NAGGI, A.; TORRI, G. Alkaline $N$-deacetylation of chitin enhanced by flash treatments . reaction kinetics and structure modifications. Carbohydrate Polymers, v. 12, p. 405-418, 1990.

BERNKOP-SCHNÜRCH, A.; DÜNNHAUPT, S. Chitosan-based drug delivery systems. European Journal of Pharmaceutics and Biopharmaceutics, v. 81, n. 3, p. 463-469, 2012. BIROLLI, W. G.; DELEZUK, J. A. D. M.; CAMPANA-FILHO, S. P. Ultrasound-assisted conversion of alpha-chitin into chitosan. Applied Acoustics, v. 103, p. 239-242, 2016.

BORNER, M.; SCHEITHAUER, W.; TWELVES, C.; MAROUN, J.; WILKE, H. Answering patients' needs: oral alternatives to intravenous therapy. The Oncologist, v. 6, suppl 4, p. 12 $16,2001$.

BRANDÃO, H. N.; DAVID, J. P.; COUTO, R. D.; NASCIMENTO, J. A. P.; DAVID, J. M. Química e farmacologia de quimioterápicos antineoplásicos derivados de plantas. Quimica Nova, v. 33, n. 6, p. 1359-1369, 2010.

BRASIL. Agência Nacional de Vigilância Sanitária (ANVISA). Resolução nº 899, de 29 de maio de 2003. Guia para validação de métodos analíticos e bioanalíticos. Diário Oficial da União, 2003.

BRAY, F.; REN, J.-S.; MASUYER, E.; FERLAY, J. Global estimates of cancer prevalence for 27 sites in the adult population in 2008. Journal International Cancer, v. 132, n. 5, p. 1133-45, mar. 2013.

CAI, J.; DANG, Q.; LIU, C.; FAN, B.; YAN, J.; XU, Y.; LI, J. Preparation and characterization of $\mathrm{N}$-benzoyl-O-acetyl-chitosan. International Journal of Biological Macromolecules, v. 77, p. 52-58, 2015. 
CALATAYUD, M.; VA, M.; DEVESA, V.; VE, D. In vitro study of intestinal transport of inorganic and methylated arsenic species by Caco-2/HT29-MTX cocultures. Chemical Research Toxicology, v.25, p. 2654-2662, 2012.

CAMPANA-FILHO, S. P.; DE BRITTO, D.; CURTI, E.; ABREU, F. R.; CARDOSO, M. B.; BATTISTI, M. V.; SIM, P. C.; GOY, R. C.; SIGNINI, R.; LAVALL, R. L. Extração, estrutura e propriedades de $\alpha$ e $\beta$-quitina. Quimica Nova, v. 30, n. 3, p. 644-650, 2007.

CARDOSO, M. B.; SIGNINI, R.; CAMPANA-FILHO, S. P. On the sonication of chitin : effects on its structure and morphology and influence on its deacetylation. Polymer Bulletin, v. 190, p. 183-190, 2001.

CAUSON, R. Validation of chromatographic methods in biomedical analysis. Viewpoint and discussion. Journal of Chromatography B: Biomedical Applications, v. 689, n. 1, p. 175$180,1997$.

CHAUVIERRE, C.; LECLERC, L.; LABARRE, D.; APPEL, M.; MARDEN, M. C.; COUVREUR, P.; VAUTHIER, C. Enhancing the tolerance of poly(isobutylcyanoacrylate) nanoparticles with a modular surface design. International Journal of Pharmaceutics, v. 338, n. 1-2, p. 327-332, 2007.

CHEN, C.; TAO, S.; QIU, X.; REN, X.; HU, S. Long-alkane-chain modified N-phthaloyl chitosan membranes with controlled permeability. Carbohydrate Polymers, v. 91, n. 1, p. 269-276, 2013.

CHEN, X.; ELISIA, I.; KITTS, D. D. Defining conditions for the co-culture of Caco-2 and HT29-MTX cells using Taguchi design. Journal of Pharmacological and Toxicological Methods, v. 61, n. 3, p. 334-342, 2010.

CHIU, Y.-L.; CHEN, S.-C.; SU, C.-J.; HSIAO, C.-W.; CHEN, Y.-M.; CHEN, H.-L.; SUNG, H.-W. pH-triggered injectable hydrogels prepared from aqueous N-palmitoyl chitosan: in vitro characteristics and in vivo biocompatibility. Biomaterials, v. 30, n. 28, p. 4877-88, 2009.

CHO, Y.; KIM, J. T.; PARK, H. J. Size-controlled self-aggregated N-acyl chitosan nanoparticles as a vitamin C carrier. Carbohydrate Polymers, v. 88, n. 3, p. 1087-1092, 2012. 
CHOI, C. Y.; KIM, S. B.; PAK, P. K.; YOO, D. I.; CHUNG, Y. S. Effect of N-acylation on structure and properties of chitosan fibers. Carbohydrate Polymers, v. 68, n. 1, p. 122-127, 2007.

CLARK, G. L.; SMITH, A. F. X-ray diffraction studies. Journal of Physical Chemistry, v. 40, n. 7, p. 863-879, 1996.

CONCHEIRO, A. Polymeric micelles as drug stabilizers : the camptothecin and simvastatin cases. Journal of Drug Delivery Science and Technology, v. 20, n. 4, p. 249-257, 2010.

CORAZZARI, I.; NISTICÒ, R.; TURCI, F.; FAGA, M. G.; FRANZOSO, F.; TABASSO, S.; MAGNACCA, G. Advanced physico-chemical characterization of chitosan by means of TGA coupled on-line with FTIR and GCMS: Thermal degradation and water adsorption capacity.

Polymer Degradation and Stability, v. 112, p. 1-9, 2015.

CROY, S. R.; KWON, G. S. Polymeric micelles for drug delivery. Current Pharmaceutical Design, v. 12, p. 4669-4684, 2006.

ALMEIDA, V. L.; LEITÃO, A.; BARRETT REINA, L. D. C.; MONTANARI, C. A.; DONNICI, C. L.; LOPES, M. T. P. Câncer e agentes antineoplásicos ciclo-celular específicos e ciclo-celular não específicos que interagem com o DNA: Uma introdução. Quimica Nova, v. 28, n. 1, p. 118-129, 2005.

SOUZA, M. V. N. Novos produtos naturais capazes de atuar na estabilização de microtúbulos, um importante alvo no combate ao câncer. Quimica Nova, v. 27, n. 2, p. 308$312,2004$.

DELEZUK, J. a D. M.; CARDOSO, M. B.; DOMARD, A.; CAMPANA-FILHO, S. P. Ultrasound-assisted deacetylation of beta-chitin: influence of processing parameters. Polymer International, v. 60, n. 6, p. 903-909, 2011.

DESBRIE, J.; BRUGNEROTTO, J.; LIZARDI, J.; GOYCOOLEA, F. M.; ARGU, W. An infrared investigation in relation with chitin and chitosan characterization. Polymer, v. 42, p. 3569-3580, 2001.

DI MARTINO, A.; SEDLARIK, V. Amphiphilic chitosan-grafted-functionalized polylactic acid based nanoparticles as a delivery system for doxorubicin and temozolomide co-therapy. International Journal of Pharmaceutics, v. 474, n. 1-2, p. 134-145, 2014. 
DUAN, K.; ZHANG, X.; TANG, X.; YU, J.; LIU, S.; WANG, D.; LI, Y.; HUANG, J.

Fabrication of cationic nanomicelle from chitosan- graft -polycaprolactone as the carrier of 7ethyl-10-hydroxy-camptothecin. Colloids and Surfaces B: Biointerfaces, v. 76, p. 475-482, 2010.

EBRAHIM ATTIA, A. B.; ONG, Z. Y.; HEDRICK, J. L.; LEE, P. P.; EE, P. L. R.; HAMMOND, P. T.; YANG, Y.-Y. Mixed micelles self-assembled from block copolymers for drug delivery. Current Opinion in Colloid \& Interface Science, v. 16, n. 3, p. 182-194, 2011.

ELKHOLY, S. S.; SALEM, H.; EWEIS, M.; ELSABEE, M. Z. Synthesis and characterization of some acyl thiourea derivatives of chitosan and their biocidal activities. International Journal of Biological Macromolecules, v. 70, p. 199-207, 2014.

FERLAY, J.; SHIN, H. R.; BRAY, F.; FORMAN, D.; MATHERS, C.; PARKIN, D. M. Estimates of worldwide burden of cancer in 2008: GLOBOCAN 2008. International Journal of Cancer, v. 127, n. 12, p. 2893-2917, 2010.

FOSSATI, L.; DECHAUME, R.; HARDILLIER, E.; CHEVILLON, D.; PREVOST, C.; BOLZE, S.; MAUBON, N. Use of simulated intestinal fluid for Caco-2 permeability assay of lipophilic drugs. International Journal of Pharmaceutics, v. 360, n. 1-2, p. 148-155, 2008. FOTAKIS, G.; TIMBRELL, J. A. In vitro cytotoxicity assays: Comparison of LDH, neutral red, MTT and protein assay in hepatoma cell lines following exposure to cadmium chloride. Toxicology Letters, v. 160, n. 2, p. 171-177, 2006.

GAO, J.; MING, J.; HE, B.; FAN, Y.; GU, Z.; ZHANG, X. Preparation and characterization of novel polymeric micelles for 9-nitro-20(S)-camptothecin delivery. European Journal of Pharmaceutical Sciences : Official Journal of the European Federation for Pharmaceutical Sciences, v. 34, n. 2-3, p. 85-93, 2008.

GAO, Y.; XIE, J.; CHEN, H.; GU, S.; ZHAO, R.; SHAO, J.; JIA, L. Nanotechnology-based intelligent drug design for cancer metastasis treatment. Biotechnology Advances, v. 32, n. 4, p. 761-777, 2014.

GONZALEZ-ALVAREZ, M.; RODRÍGUEZ-BERNA, G.; MANGAS-SANJU, V.; GARCÍA-GIM, L. A promising camptothecin derivative : Semisynthesis , antitumor activity and intestinal permeability. European Journal of Medicinal Chemistry journal, v. 83, p. 366-373, 2014. 
GUO, B.-L.; GAO, Q.-Y. Preparation and properties of a $\mathrm{pH} /$ temperature-responsive carboxymethyl chitosan/poly(N-isopropylacrylamide)semi-IPN hydrogel for oral delivery of drugs. Carbohydrate Research, v. 342, n. 16, p. 2416-22, 2007.

HALFDANARSON, T. R.; JATOI, A. Oral cancer chemotherapy: The critical interplay between patient education and patient safety. Current Oncology Reports, v. 12, n. 4, p. $247-$ 252,2010

HEJAZI, R.; AMIJI, M. Chitosan-based gastrointestinal delivery systems. Journal of Controlled Release, v. 89, n. 2, p. 151-165, 2003.

HERTZBERG, R. P.; CARANFA, M. J.; HECHT, S. M. On the mechanism of topoisomerase I inhibition by camptothecin: evidence for binding to an enzyme-DNA complex.

Biochemistry, v. 28, p. 4629-4638, 1989.

HEUX, L.; BRUGNEROTTO, J.; DESBRIÈRES, J.; VERSALI, M. F.; RINAUDO, M. Solid state NMR for determination of degree of acetylation of chitin and chitosan.

Biomacromolecules, v. 1, n. 4, p. 746-751, 2000.

HICKEY, J. W.; SANTOS, J. L.; WILLIFORD, J. M.; MAO, H. Q. Control of polymeric nanoparticle size to improve therapeutic delivery. Journal of Controlled Release, v. 219, p. 535-547, 2015.

HILGENDORF, C.; SPAHN-LANGGUTH, H.; REGÅRDH, C. G.; LIPKA, E. Caco-2 versus Caco-2 / HT29-MTX co-cultured cell lines : permeabilities via diffusion, inside- and outsidedirected carrier-mediated transport. Journal of Pharmaceutical Sciences, v. 89, n. 1, p. 6375,2000 .

HIRAI, A.; ODANI, H.; NAKAJIMA, A. Determination of degree of deacetylation of chitosan by 1H NMR spectroscopy. Polymer Bulletin, v. 94, p. 87-94, 1991.

HIRANO, S.; YAMAGUCHI, Y.; KAMIYA, M. Novel N-saturated-fatty-acyl derivatives of chitosan soluble in water and in aqueous acid and alkaline solutions. Carbohydrate Polymers, v. 48, p. 203-207, 2002.

HOLME, H. K.; FOROS, H.; PETTERSEN, H.; DORNISH, M.; SMIDSRØD, O. Thermal depolymerization of chitosan chloride. Carbohydrate Polymers, v. 46, n. 3, p. 287-294, 2001. 
HU, Y.; DU, Y.; YANG, J.; TANG, Y.; LI, J.; WANG, X. Self-aggregation and antibacterial activity of N-acylated chitosan. Polymer, v. 48, n. 11, p. 3098-3106, 2007.

HUININK, W. W. T. B.; TERWOGT, J. M. M.; BEIJNEN, J. H.; NUIJENT, B.; LEEUWENHOEK, A. Van. Alternative formulations of paclitaxel. Cancer Treatment Review, v. 23, p. 87-95, 1997.

HUO, M.; ZHANG, Y.; ZHOU, J.; ZOU, A.; LI, J. Formation, microstructure, biodistribution and absence of toxicity of polymeric micelles formed by N-octyl-N,O-carboxymethyl chitosan. Carbohydrate Polymers, v. 83, n. 4, p. 1959-1969, 2011.

INGELS, F.; BECK, B.; OTH, M.; AUGUSTIJNS, P. Effect of simulated intestinal fluid on drug permeability estimation across Caco-2 monolayers. International Journal of Pharmaceutics, v. 274, n. 1-2, p. 221-232, 2004.

INGELS, F.; DEFERME, S.; DESTEXHE, E.; OTH, M.; VAN DEN MOOTER, G.; AUGUSTIJNS, P. Simulated intestinal fluid as transport medium in the Caco-2 cell culture model. International Journal of Pharmaceutics, v. 232, n. 1-2, p. 183-192, 2002.

INSTITUTO NACIONAL DE CÂNCER JOSÉ ALENCAR GOMES DA SILVA (INCA).Estimativa 2014: incidência de câncer no Brasil. Rio de Janeiro: INCA, 2014. 124p. Disponível em: $<$ http://www.saude.sp.gov.br/resources/ses/perfil/gestor/homepage/outrosdestaques/estimativa-de-incidencia-de-cancer-2014/estimativa_cancer_24042014.pdf>. Acesso em:31 maio. 2017.

INSTITUTO NACIONAL DE CÂNCER JOSÉ ALENCAR GOMES DA SILVA (INCA). Estimativa 2016: incidência de câncer no Brasil. Rio de Janeiro: INCA, 2015. 122p. Disponível em: <http://www.inca.gov.br/estimativa/2016/estimativa-2016-v11.pdf>. Acesso em: 31 maio. 2017.

ISHIHARA, M.; FUJITA, M.; KISHIMOTO, S.; HATTORI, H.; KANATANI, Y. Biological , chemical , and physical compatibility of chitosan and biopharmaceuticals. In: SARMENTO, B.; NEVES, J. (Ed.). Chitosan-based systems for biopharmaceuticals: Delivery, targeting and polymer therapeutics. New York: John Wiley, 2012. p. 93-106.

JEMAL, A.; SIEGEL, R.; XU, J.; WARD, E. Cancer Statistics, 2010. American Cancer Society, v. 60, n. 5, p. 277-300, 2010. 
JIANG, G.-B. B.; QUAN, D.; LIAO, K.; WANG, H. Novel polymer micelles prepared from chitosan grafted hydrophobic palmitoyl groups for drug delivery. Molecular Pharmaceutics, v. 3, n. 2, p. 152-160, 2006.

JIANG, G.-B.; QUAN, D.; LIAO, K.; WANG, H. Preparation of polymeric micelles based on chitosan bearing a small amount of highly hydrophobic groups. Carbohydrate Polymers, v. 66, n. 4, p. 514-520, 2006b.

JINTAPATTANAKIT, A.; MAO, S.; KISSEL, T.; JUNYAPRASERT, V. B.

Physicochemical properties and biocompatibility of N-trimethyl chitosan: Effect of quaternization and dimethylation. European Journal of Pharmaceutics and

Biopharmaceutics, v. 70, n. 2, p. 563-571, 2008.

JOHNSON, R. L.; SCHMIDT-ROHR, K. Quantitative solid-state 13C NMR with signal enhancement by multiple cross polarization. Journal of Magnetic Resonance, v. 239, p. 4449, 2014.

KHAN, A. M.; SHAH, A. M. Determination of critical micelle $(\mathrm{cmc})$ of sodium dedecyl sulfate (SDs) and effect of low concentration of pyrene on its Cmc using ORIGIN software. Journal of The Chemical Society of Pakistan, v. 30, n. 2, p. 186-191, 2008.

KACPRZAK, K. Chemistry and biology of camptothecin and its derivatives. In:

RAMAWAT, K. G.; MERILLON, I. M. (Ed.).Natural products:phytochemistry, botany and metabolism of alkaloids, phenolecs and terpenes. Berlin: Springer-Verlag, 2013. p. 643-682.

KOLHATKAR, R. B.; SWAAN, P.; GHANDEHARI, H. Potential oral delivery of 7-ethyl10-hydroxy-camptothecin ( SN-38) using poly ( amidoamine ) dendrimers. Pharmaceutical Research, v. 25, n. 7, p. 1723-1729, 2008.

KWON, G. S.; OKANO, T. Polymeric micelles as new drug carriers. Advanced Drug Delivery Reviews, v. 21, n. 2, p. 107-116, 1996.

LASKAR, P.; SAMANTA, S.; KUMAR, S.; DEY, J. evaluation of pH-sensitive cholesterolcontaining stable polymeric micelles for delivery of camptothecin. Journal of Colloid and Interface Science, v. 430, p. 305-314, 2014.

LE TIEN, C.; LACROIX, M.; ISPAS-SZABO, P.; MATEESCU, M.-A. N-acylated chitosan: hydrophobic matrices for controlled drug release. Journal of Controlled Release, v. 93, n. 1, p. 1-13, 2003. 
LEE, K. Y.; JO, W. H.; KWON, I. C.; KIM, Y.-H.; JEONG, S. Y. Physicochemical characteristics of self-aggregates of hydrophobically modified chitosans. Langmuir, v. 14, n. 9, p. 2329-2332, 1998.

LEITHNER, K.; BERNKOP-SCHN, A. Chitosan and derivatives for biopharmaceutical use : mucoadhesive properties. In: SARMENTO, B.; NEVES, J. (Ed.). Chitosan-based systems for biopharmaceuticals: Delivery, Targeting and Polymer Therapeutics. New York: John Wiley, 2012. p. 159-180.

LIND, M. L.; JACOBSEN, J.; HOLM, R.; MÜLLERTZ, A. Development of simulated intestinal fluids containing nutrients as transport media in the Caco-2 cell culture model: Assessment of cell viability, monolayer integrity and transport of a poorly aqueous soluble drug and a substrate of efflux mechanisms. European Journal of Pharmaceutical Sciences, v. 32, n. 4-5, p. 261-270, 2007.

LIU, Y.; KONG, M.; FENG, C.; YANG, K. K.; LI, Y.; SU, J.; CHENG, X. J.; PARK, H. J.; CHEN, X. G. Biocompatibility, cellular uptake and biodistribution of the polymeric amphiphilic nanoparticles as oral drug carriers. Colloids and Surfaces B: Biointerfaces, v. 103, p. 345-353, 2013.

LUO, P.; LUO, Y.; HUANG, J.; LU, W.; LUO, D.; YU, J.; LIU, S. Incorporation of camptothecin into reduction-degradable supramolecular micelles for enhancing its stability. Colloids and Surfaces B: Biointerfaces, v. 109, p. 167-175, 2013.

LV, J.; ZHOU, Q.; LIU, G.; GAO, D.; WANG, C. Preparation and properties of polyester fabrics grafted with O-carboxymethyl chitosan. Carbohydrate Polymers, v. 113, p. 344-352, 2014.

MA, G.; YANG, D.; KENNEDY, J. F.; NIE, J. Synthesize and characterization of organic-soluble acylated chitosan. Carbohydrate Polymers, v. 75, n. 3, p. 390-394, 2009.

\section{MARINA, A.; ALMEIDA, D. E. S. Development of chitosan-grafted polycaprolactone} copolymer for mucoadhesive nanodelivery systems. 2016. 91 f. Dissertação (Mestrado em Engenharia Biomédica)- Faculdade de Engenharia, Universidade do Porto, Porto, 2016.

MARTIN, L.; WILSON, C. G.; KOOSHA, F.; TETLEY, L.; GRAY, A. I.; SENEL, S.; UCHEGBU, I. F. The release of model macromolecules may be controlled by the hydrophobicity of palmitoyl glycol chitosan hydrogels. Journal of Controlled Release : Official Journal of the Controlled Release Society, v. 80, n. 1-3, p. 87-100, 2002. 
MCCARRON, P.; WOOLFSON, D.; KEATING, S. M. Response surface methodology as a predictive tool for determining the effects of preparation conditions on the physicochemical properties of poly(isobutylcyanoacrylate) nanoparticles. International Journal of Pharmaceutics, v. 193, n. 1, p. 37-47, 1999.

MI, Z.; BURKE, T. G. Differential interactions of camptothecin lactone and carboxylate forms with human blood components. Biochemistry, v. 33, n. 614, p. 10325-10336, 1994.

MISHRA, B.; PATEL, B. B.; TIWARI, S. Colloidal nanocarriers: a review on formulation technology, types and applications toward targeted drug delivery. Nanomedicine :

Nanotechnology, Biology, and Medicine, v. 6, n. 1, p. 9-24, 2010.

MIWA; A., ISHIBE, A.; NAKANO, M.; YAMAHIRA, T.; ITAI, S.; JINNO, S.;

KAWAHARA, H. Development of novel chitosan derivatives as micellar carriers of taxol.Pharmaceutical Research, v. 15, n. 12, p. 1844-1850, 1998.

MO, R.; JIN, X.; LI, N.; JU, C.; SUN, M.; ZHANG, C.; PING, Q. The mechanism of enhancement on oral absorption of paclitaxel by N-octyl-O-sulfate chitosan micelles.

Biomaterials, v. 32, n. 20, p. 4609-4620, 2011.

MOSMANN, T. Rapid colorimetric assay for cellular growth and survival: Application to proliferation and cytotoxicity assays. Journal of Immunological Methods, v. 65, n. 1-2, p. $55-63,1983$.

MULEY, P.; KUMAR, S.; EL KOURATI, F.; KESHARWANI, S. S.; TUMMALA, H. Hydrophobically modified inulin as an amphiphilic carbohydrate polymer for micellar delivery of paclitaxel for intravenous route. International journal of pharmaceutics, v. 500, n. $1-2$, p. $32-41,2016$.

NAM, J. P.; PARK, S. C.; KIM, T. H.; JANG, J. Y.; CHOI, C.; JANG, M. K.; NAH, J. W. Encapsulation of paclitaxel into lauric acid-O-carboxymethyl chitosan-transferrin micelles for hydrophobic drug delivery and site-specific targeted delivery. International Journal of Pharmaceutics, v. 457, n. 1, p. 124-135, 2013.

O’NEILL, V. J.; TWELVES, C. J. Oral cancer treatment: developments in chemotherapy and beyond. British Journal of Cancer, v. 87, n. 9, p. 933-937, 2002.

OGAWA, K. Effect of heating an aqueous suspension of chitosan on the crystallinity and polymorphs. Agricultural and Biological Chemistry, v. 55, n. 9, p. 2375-2379, 1991. 
OGAWA, K.; HIRANO, S.; MIYANISHI, T.; YUI, T.; WATANABE, T. A new polymorph of chitosan. Macromolecule, v. 17, p. 973-975, 1984.

OKUYAMA, K.; NOGUCHI, K.; HANAFUSA, Y.; OSAWA, K.; OGAWA, K. Structural study of anhydrous tendon chitosan obtained via chitosan/acetic acid complex. International Journal of Biological Macromolecules, v. 26, n. 4, p. 285-293, 1999.

OMAR, R.; BARDOOGO, Y. L.; COREM-SALKMON, E.; MIZRAHI, B. Amphiphilic star PEG-camptothecin conjugates for intracellular targeting. Journal of Controlled Release Journal, 2016. In press. Disponível em: $<\underline{\text { http://www.sciencedirect.com/science/article/pii/S0168365916308008> }}$. Acesso em: 31 maio. 2017.

OPANASOPIT, P.; YOKOYAMA, M.; WATANABE, M.; KAWANO, K.; MAITANI, Y.; OKANO, T. Influence of serum and albumins from different species on stability of camptothecin-loaded micelles. Journal of Controlled Release, v. 104, n. 2, p. 313-321, 2005.

OTTØY, M. H.; VÅRUM, K. M.; SMIDSRØD, O. Compositional heterogeneity of heterogeneously deacetylated chitosans. Carbohydrate Polymers, v. 29, n. 1, p. 17-24, 1996.

PAN, Z.; GAO, Y.; HENG, L.; LIU, Y.; YAO, G.; WANG, Y.; LIU, Y. Amphiphilic N(2,3-dihydroxypropyl)-chitosan-cholic acid micelles for paclitaxel delivery.

Carbohydrate Polymers, v. 94, n. 1, p. 394-9, 2013.

PANCHAGNULA, R. Pharmaceutical aspects of paclitaxel. International Journal of Pharmaceutics, v. 172, p. 1-15, 1998.

PARK, J. H.; SARAVANAKUMAR, G.; KIM, K.; KWON, I. C. Targeted delivery of low molecular drugs using chitosan and its derivatives. Advanced Drug Delivery Reviews, v. 62, n. 1 , p. $28-41,2010$.

PHILIPPI, C.; LORETZ, B.; SCHAEFER, U. F.; LEHR, C. Application of Chitosan for Anticancer Biopharmaceutical Delivery. In: SARMENTO, B.; NEVES, J. (Ed.). Chitosanbased systems for biopharmaceuticals: Delivery, targeting and polymer therapeutics. New York: John Wiley, 2012. p. 381-392. 
PONTIER, C.; PACHOT, J.; BOTHAM, R.; LENFANT, B.; ARNAUD, P. HT29-MTX and Caco-2 / TC7 Monolayers as predictive models for human intestinal absorption : role of the mucus layer. Journal of Pharmaceutical Sciences, v. 90, n. 10, p. 1608-1619, 2001.

PREZOTTI, F. G. Micro/nanopartículas mucoadesivas de goma gelana e pectina para a liberação cólon-específica do resveratrol. 2017. 302 f. Tese (Doutorado em Ciências Farmacêuticas) - Faculdade de Ciências Farmacêuticas, Universidade Estadual Paulista "Júlio de Mesquita Filho", Araraquara, 2017.

PRICE, C. Micelle formation by copolymers in organic solvents. Pure and Applied Chemistry, v. 55, n. 10, p. 1563-1572, 1983.

PRICE, G. Ultrasonically enhanced polymer synthesis. Ultrasonics Sonochemistry, v. 3, n. 3, p. S229-S238, 1996.

RAO, J. P.; GECKELER, K. E. Polymer nanoparticles: Preparation techniques and sizecontrol parameters. Progress in Polymer Science, v. 36, n. 7, p. 887-913, 2011.

RINAUDO, M. Chitin and chitosan: Properties and applications. Progress in Polymer Science, v. 31, n. 7, p. 603-632, 2006.

ROCHA, R. A.; VÉLEZ, D.; DEVESA, V. In vitro evaluation of intestinal fluoride absorption using different cell models. Toxicology Letters, v. 210, n. 3, p. 311-317, 2012.

ROGER, E.; LAGARCE, F.; GARCION, E.; BENOIT, J.-P. Biopharmaceutical parameters to consider in order to alter the fate of nanocarriers after oral delivery. Nanomedicine (London, England), v. 5, n. 2, p. 287-306, 2010.

SARISOZEN, C.; ABOUZEID, A. H.; TORCHILIN, V. P. The effect of co-delivery of paclitaxel and curcumin by transferrin-targeted PEG-PE-based mixed micelles on resistant ovarian cancer in 3-D spheroids and in vivo tumors. European Journal of Pharmaceutics and Biopharmaceutics, v. 88, n. 2, p. 539-550, 2014.

SARMENTO, B.; RIBEIRO, A.; VEIGA, F.; SAMPAIO, P.; NEUFELD, R.; FERREIRA, D. Alginate/chitosan nanoparticles are effective for oral insulin delivery. Pharmaceutical Research, v. 24, n. 12, p. 2198-2206, 2007.

SHAH, P.; JOGANI, V.; BAGCHI, T.; MISRA, A. Role of Caco-2 cell monolayers in prediction of intestinal drug absorption. Biotechnology Progress, v. 22, p. 186-198, 2006. 
SIGNINI, R.; CAMPANA FILHO, S. P. Características e propriedades de quitosanas purificadas nas formas neutra, acetato e cloridrato. Polímeros, v. 11, n. 2, p. 58-64, 2001.

SILVA, D. S.; ALMEIDA, A.; PREZOTTI, F.; CURY, B.; CAMPANA-FILHO, S. P.; SARMENTO, B. Synthesis and characterization of 3,6-O,O'- dimyristoyl chitosan micelles for oral delivery of paclitaxel. Colloids and Surfaces B: Biointerfaces, v. 152, p. 220-228, 2017.

SILVA, D. S.; DELEZUK, J. A. M.; PORTA, F. A.; LONGO, E.; CAMPANA-FILHO, S. P. Comparison of experimental and theoretical data on the structural and electronic characterization of chitin and chitosan. Current Physical Chemistry, v. 5, p. 1-8, 2015. SINGLA, A. K.; GARG, A.; AGGARWAL, D. Paclitaxel and its formulations. International Journal of Pharmaceutics, v. 235, n. 1-2, p. 179-192, 2002.

SUN, L.; DU, Y.; FAN, L.; CHEN, X.; YANG, J. Preparation, characterization and antimicrobial activity of quaternized carboxymethyl chitosan and application as pulp-cap. Polymer, v. 47, n. 6, p. 1796-1804, 2006.

TABETA, R.; DIVISION, B.; OGAWA, K.; OCTOBER, R. High-resolution solid-state 13C NMR study of chitosan and its salts with acids: conformational characterization of polymorphs and helical structures as viewed from the conformation-dependent ${ }^{13} \mathrm{C}$ chemical shifts. Macromolecules, v. 20, p. 2424-2430, 1987.

TAVARES, G. D. Nanopartículas de poli ( $\mathbf{N}$-butil-cianoacrilato ) revestidas com $\mathbf{N}, \mathbf{N}$, $\mathrm{N}$-trimetilquitosana : desenvolvimento, caracterização e estudos de permeabilidade in vitro. 2013. 214 f. Tese (Doutorado em Ciências Farmacêuticas) - Faculdade de Ciências Farmacêuticas, Universidade de São Paulo, São Paulo, 2013.

TONG, Y.; WANG, S.; XU, J.; CHUA, B.; HE, C. Synthesis of O,O'-dipalmitoyl chitosan and its amphiphilic properties and capability of cholesterol absorption. Carbohydrate Polymers, v. 60, n. 2, p. 229-233, 2005.

TOZAKI, H.; KOMOIKE, J.; TADA, C.; MARUYAMA, T.; TERABE; SUZUKI, T.; YAMAMOTO; MURANISHI, S. Chitosan capsules for colon-specific drug delivery: improvement of insulin absorption from the rat colon. Journal of Pharmaceutical Sciences, v. 86, n. 9, p. 1016-1021, 1997. 
UCHEGBU, I. F.; CARLOS, M.; MCKAY, C.; HOU, X.; SCHÄTZLEIN, A. G. Chitosan amphiphiles provide new drug delivery opportunities. Polymer International, v. 63, n. 7, p. 1145-1153, 2014.

VAN NAGELL, J. R.; DEPRIEST, P. D.; UELAND, F. R.; DESIMONE, C. P.; COOPER, A. L.; MCDONALD, J. M.; PAVLIK, E. J.; KRYSCIO, R. J.; TWICKLER, D. M.; MOSCHOS, E.; KARLAN, B. Y.; PLATT, L. D.; FISHMAN, D. a; COHEN, L.; BLANK, S. V; SHULMAN, L.; SINGH, D.; BOZORGI, K.; TAMURA, R.; TIMOR-TRITSCH, I. I.; SCHWARTZ, P. E.; SIEGEL, R.; NAISHADHAM, D.; JEMAL, A.; LUIS, J.; SASSONE, A.; MEIRE, H.; FARRANT, P.; GUHA, T.; GRANBERG, S.; NORSTRÖM, A.; WIKLAND, M.; FERRAZZI, E.; ZANETTA, G.; FLEISCHER, A. C.; LYSHCHIK, A.; HIRARI, M.; MOORE, R. D.; ABRAMSON, R. G.; GALLION, H. H. Ultrasound and assessment of ovarian cancer risk. Cancer, v. 37, n. 2, p. 408-14, 2013.

WANG, J.; JIN, X.; CHANG, D. Chemical modification of chitosan under high-intensity ultrasound and properties of chitosan derivatives. Carbohydrate Polymers, v. 78, n. 1, p. 175-177, 2009.

WIKMAN, A.; KARLSSON, J.; CARLSTEDT, I.; ARTURSSON, P. A drug absorption model based on the mucus layer producing human intestinal goblet cell line HT29-H. Pharmaceutical Research, v. 10, n. 6, p. 843-852, 1993.

WORAPHATPHADUNG, T.; SAJOMSANG, W.; GONIL, P.; TREETONG, A.; AKKARAMONGKOLPORN, P.; NGAWHIRUNPAT, T.; OPANASOPIT, P. pHResponsive polymeric micelles based on amphiphilic chitosan derivatives: effect of hydrophobic cores on oral meloxicam delivery. International Journal of Pharmaceutics, v. 497, n. 1-2, p. 150-160, 2016.

WALTER, E., JANICH, S. J., ROESSLER B., HILFINGER, J. M AMIDON, G. L. HT29MTX / Caco-2 cocultures as an in vitro model for the intestinal epithelium : in vitro - in vivo correlation with permeability data from rats and humans. Journal of Pharmaceutical Sciences, v. 85, n. 10, p. 1070-1076, 1996.

XIAO, B.; SI, X.; HAN, M. K.; VIENNOIS, E.; ZHANG, M.; MERLIN, D. Cationic polymeric nanoparticles for synergistic colon cancer combination chemotherapy. Journal of Materials Chemistry B, v. 1, n. 1, p. 1-10, 2015. 
XIE, X.; LI, F.; ZHANG, H.; LU, Y.; LIAN, S.; LIN, H.; GAO, Y.; JIA, L. EpCAM aptamerfunctionalized mesoporous silica nanoparticles for efficient colon cancer cell-targeted drug delivery. European Journal of Pharmaceutical Sciences, v. 83, p. 28-35, 2016.

YAO, Z.; ZHANG, C.; PING, Q.; YU, L. A series of novel chitosan derivatives: synthesis, characterization and micellar solubilization of paclitaxel. Carbohydrate Polymers, v. 68, n. 4, p. 781-792, 2007.

YE, Y. Q.; YANG, F. L.; HU, F. Q.; DU, Y. Z.; YUAN, H.; YU, H. Y. Core-modified chitosan-based polymeric micelles for controlled release of doxorubicin. International Journal of Pharmaceutics, v. 352, p. 294-301, 2008.

YEH, T. H.; HSU, L. W.; TSENG, M. T.; LEE, P. L.; SONJAE, K.; HO, Y. C.; SUNG, H. W. Mechanism and consequence of chitosan-mediated reversible epithelial tight junction opening. Biomaterials, v. 32, n. 26, p. 6164-6173, 2011.

YOU, J.; HU, F.-Q.; DU, Y.-Z.; YUAN, H.; YE, B.-F. High cytotoxicity and resistant-cell reversal of novel paclitaxel loaded micelles by enhancing the molecular-target delivery of the drug. Nanotechnology, v. 18, n. 49, p. 495101, 2007.

YUAN, H.; LU, L.; DU, Y.; HU, F. Stearic acid- g -chitosan polymeric micelle for oral drug delivery : in vitro transport and in vivo absorption. Molecular Pharmaceutics, v. 8, n. 1, p. 225-238, 2010.

ZHANG, C.; DING, Y.; LUCY, L.; PING, Q. Polymeric micelle systems of hydroxycamptothecin based on amphiphilic $\mathrm{N}$-alkyl- $\mathrm{N}$-trimethyl chitosan derivatives.

Colloids and Surfaces B: Biointerfaces, v. 55, p. 192-199, 2007.

ZHANG, C.; PING, Q.; ZHANG, H.; SHEN, J. Preparation of N-alkyl-O-sulfate chitosan derivatives and micellar solubilization of taxol. Carbohydrate Polymers, v. 54, p. 137-141, 2003.

ZHANG, C.; QINENG, P.; ZHANG, H. Self-assembly and characterization of paclitaxelloaded N-octyl-O-sulfate chitosan micellar system. Colloids and Surfaces B: Biointerfaces, v. 39, n. 1-2, p. 69-75, 2004.

ZUÑIGA, A.; DEBBAUDT, A.; ALBERTENGO, L.; RODRÍGUEZ, M. S. Synthesis and characterization of N-propyl-N-methylene phosphonic chitosan derivative. Carbohydrate Polymers, v. 79, n. 2, p. 475-480, 2010. 


\section{Massa molar média viscosimétrica}

Para a determinação da viscosidade intrínseca, cerca de $20 \mathrm{mg}$ de quitosana (previamente seca em estufa, a vácuo, a $30^{\circ} \mathrm{C}$, durante 6 horas) foram suspensos em $25 \mathrm{~mL}$ de solução de ácido acético 0,6M, sob agitação magnética constante, durante 24 horas. Em seguida, foram adicionados $25 \mathrm{~mL}$ de acetato de sódio $0,4 \mathrm{M}$. A agitação continuou por mais 24 horas. A solução resultante foi filtrada sob pressão positiva, em membrana com diâmetro dos poros de 0,45 $\mu \mathrm{m}$ (Millipore - White SCWP). Alíquotas de $15 \mathrm{~mL}$ desta solução foram transferidas para um viscosímetro capilar de vidro (do tipo Ubbelohde, $\phi=0,53 \mathrm{~mm}$ ) e as medidas de tempo de escoamento foram determinadas em um viscosímetro AVS-350, acoplado a um módulo diluidor automático AVS-20, ambos da Schott-Geräte. Todas as medidas de tempo de escoamento foram realizadas a $25,00 \pm 0,01^{\circ} \mathrm{C}$, empregando um tampão ácido acético $0,3 \mathrm{M}$ /acetato de sódio $0,2 \mathrm{M}$ $(\mathrm{pH}=4,5)$, para as sucessivas diluições, de modo a assegurar que a força iônica das soluções fosse mantida constante.

A viscosidade intrínseca foi obtida a partir da relação de Huggins

$$
\eta_{s p} / C=[\eta] \cdot+\mathrm{k}_{\mathrm{H}} \cdot[\eta]^{2} \cdot \mathrm{C}
$$

onde: $\eta_{s p} / C=$ viscosidade reduzida $(\mathrm{mL} / \mathrm{g}) ;[\eta]=$ viscosidade intrínseca $(\mathrm{mL} / \mathrm{g}) ; \mathrm{k}_{\mathrm{H}}=$ constante de Huggins; $\mathrm{C}$ = concentração da solução $(\mathrm{g} / \mathrm{mL})$.

Desta forma, a viscosidade intrínseca $([\eta])$ é determinada pela extrapolação à diluição infinita da curva de viscosidade reduzida versus concentração. A viscosidade assim 
determinada satisfaz a relação de Mark-Houwink. Dessa forma, a massa molar média viscosimétrica $\left(\overline{M_{v}}\right)$ do polieletrólito pode ser determinada empregando a.

$$
[\eta]=\mathrm{K}^{\prime} \overline{M_{v}}{ }^{\alpha}
$$

onde: K' e $\alpha$ são constantes para um dado solvente e temperatura. Para a quitosana, os valores de $\alpha$ e de K' dependem do grau médio de acetilação do polímero 


\title{
Trabalhos Publicados no doutorado
}

\author{
Artigos publicados
}

ALMEIDA, A.; SILVA, D.; GONÇALVES, V.; SARMENTO, B. Synthesis and characterization of chitosan-grafted-polycaprolactone micelles for modulate intestinal paclitaxel delivery. Drug Delivery and Translational Research, v. 7, n. 36, p. 1-11, 2017.

SILVA, D. S.; ALMEIDA, A.; PREZOTTI, F.; CURY, B.; CAMPANA-FILHO, S. P.; SARMENTO, B. Synthesis and characterization of 3,6-O,O'- dimyristoyl chitosan micelles for oral delivery of paclitaxel. Colloids and Surfaces B: Biointerfaces, v. 152, p. 220-228, 2017.

SILVA, D. S.; DELEZUK, J. A. M.; PORTA, F. A.; LONGO, E.; CAMPANA-FILHO, S. P. Comparison of experimental and theoretical data on the structural and electronic characterization of chitin and chitosan. Current Physical Chemistry, v. 5, p. 1-8, 2015.

\section{Artigo aceito}

DANIELLA SILVA, ANDREIA ALMEIDA, FABÍOLA PREZOTTI, WILLIAM FACCHINATTO, LUIZ COLNAGO, SÉRGIO CAMPANA-FILHO, BRUNO SARMENTO, Self-aggregates of 3,6-O,O'-dimyristoylchitosan derivative are effective in enhancing the solubility and intestinal permeability of camptothecin, Carbohydrate Polymers.(In press).

\section{Capítulos de livro}

S. SILVA, DANIELLA; SÉRIGO PAULO CAMPANA FILHO; A. FIAMINGO; MARTINS, D; BUKZEM, A.; PAVINATTO, A.; W. M. FACCHINATTO; SENRA; T.Chemically Modified Chitosan Derivatives In: Chemically Modified Chitosan Derivatives.1 ed.Sharjah, Emirados Árabes Unido : Bentham eBooks, 2017, v.3, p. 111-137. 
SILVA, D. S.; ALMEIDA, A.M; P. CAMPANA-FILHO, SERGIO; SARMENTO, B. Synthesis and applications of amphiphilic chitosan derivatives for drug delivery applications In: Nanoparticles in the Life Sciences and Biomedicine.1 ed. : Panstanford Publishing;, 2016. 